NBER WORKING PAPER SERIES

\title{
RETAIL GLOBALIZATION AND HOUSEHOLD WELFARE: EVIDENCE FROM MEXICO
}

\author{
David Atkin \\ Benjamin Faber \\ Marco Gonzalez-Navarro \\ Working Paper 21176 \\ http://www.nber.org/papers/w21176
}

\author{
NATIONAL BUREAU OF ECONOMIC RESEARCH \\ 1050 Massachusetts Avenue \\ Cambridge, MA 02138 \\ May 2015
}

We are grateful to Hector Guzmán at Banco de México and Mauricio Varela at Arizona for providing us with the retail openings data. We also thank Rafael Posse and Javier Romero at INEGI, and José Antonio Murillo at Banco de México for providing us access to the non-public access microdata of the Mexican CPI. Etienne Gagnon at the Fed Board in Washington D.C. kindly shared his data on the public access part of the Mexican CPI. Natalia Volkow at INEGI was pivotal in gaining access to the confidential microdata of the Mexican retail census. We are also grateful to the Mexico City office of a large international market research company for supporting an academic collaboration and granting us access to their uncensored barcode-level consumption microdata, and to Enrique Seira Bejarano and Paul Gertler who were instrumental in making that happen. Finally, we thank Costas Arkolakis, Dominick Bartelme, Jonathan Eaton, Jessie Handbury, Erik Hurst, Seema Jayachandran, Dan Keniston, Dmitri Koustas, David Lagakos, Natalia Ramondo, Steve Redding, Andrés Rodríguez-Clare and participants at multiple seminars for helpful comments. This research has been supported by funding from the Ontario Work-Study Program. This research has been supported by funding from the OntarioWork-Study Program. The views expressed herein are those of the authors and do not necessarily reflect the views of the National Bureau of Economic Research.

NBER working papers are circulated for discussion and comment purposes. They have not been peerreviewed or been subject to the review by the NBER Board of Directors that accompanies official NBER publications.

(C) 2015 by David Atkin, Benjamin Faber, and Marco Gonzalez-Navarro. All rights reserved. Short sections of text, not to exceed two paragraphs, may be quoted without explicit permission provided that full credit, including $(\mathcal{C}$ notice, is given to the source. 
Retail Globalization and Household Welfare: Evidence from Mexico

David Atkin, Benjamin Faber, and Marco Gonzalez-Navarro

NBER Working Paper No. 21176

May 2015, Revised January 2016

JEL No. F15,F23,F63,O24

\begin{abstract}
The arrival of global retail chains in developing countries is causing a radical transformation in the way that households source their consumption. This paper draws on a new collection of Mexican microdata to estimate the effect of foreign supermarket entry on household welfare. The richness of the microdata allows us to estimate a general expression for the gains from retail FDI, and to decompose these gains into several distinct channels. We find that foreign retail entry causes large and significant welfare gains for the average household that are mainly driven by a reduction in the cost of living. About one quarter of this price index effect is due to pro-competitive effects on the prices charged by domestic stores, with the remaining three quarters due to the direct consumer gains from shopping at the new foreign stores. In contrast, we find little evidence of significant changes in average municipality-level incomes or employment. We do, however, find evidence of store exit, adverse effects on domestic store profits and reductions in the incomes of traditional retail sector workers. We also show that the gains from retail FDI are on average positive for all income groups but regressive, and quantify the opposing forces that underlie this finding. Finally, we find that the estimated gains are specific to foreign entry, rather than being driven by the entry of modern store formats more generally.
\end{abstract}

David Atkin

Department of Economics

MIT

77 Massachusetts Avenue E19-750

Cambridge, MA 02139

and NBER

atkin@mit.edu

Benjamin Faber

Department of Economics

University of California, Berkeley

697A Evans Hall

Berkeley, CA 94720

and NBER

benfaber@econ.berkeley.edu
Marco Gonzalez-Navarro

University of Toronto

121 St. George Street

Toronto, Otario

M5S 2E8

Canada

marco.gonzalez.navarro@utoronto.ca 


\section{Introduction}

A radical transformation is occurring in the way households in developing countries source their consumption. A key driver of this so called 'supermarket revolution' has been the arrival of global retail chains in developing countries (Reardon et al., 2003; Humphrey, 2007; and Bronnenberg and Ellickson 2015). ${ }^{1}$ This process of retail globalization has led to heated policy debates. Those against foreign retailers point to the large share of employment in the traditional retail sector, while those in favor emphasize potential benefits from lower consumer prices.

Importantly, these debates have also led to stark differences in policies towards retail FDI across developing countries. While some countries such as Argentina, Brazil, Mexico and most of Eastern Europe chose to fully liberalize retail FDI at the beginning of the 1990s, several developing countries including India continue to severely restrict foreign retail entry and others such as Indonesia, Malaysia and Thailand re-imposed regulatory barriers on foreign retailers after initially allowing entry (Dufey et al., 2008; Wrigley and Lowe, 2010). ${ }^{2}$ These policy differences matter because retail is a key sector of the economy in terms of both employment and consumption, on average accounting for 15-20 percent of total employment, 10-15 percent of total GDP, and more than 50 percent of total household expenditure in developing countries. ${ }^{3}$

Despite the rapid globalization of retail in the developing world and widespread policy interest, the existing literatures in trade and development have so far paid relatively little attention to this facet of international integration. This paper seeks to fill that gap. We bring together a new and uniquely rich collection of microdata to assess the consequences of retail FDI in the context of Mexico, a country whose retail landscape underwent a dramatic transformation as foreign retailers came to dominate its market over the last 20 years. Our analysis coincides with the major wave of foreign store expansion in Mexico. Over our sample period, January 2002 to March 2014 , the number of foreign supermarkets close to quadrupled from 365 to 1,335 stores. This rapid expansion provides an ideal empirical setting to study the impact of retail globalization.

This paper aims to contribute to our understanding of three central questions: 1) What is the effect of retail FDI on average household welfare in the municipality of entry?; 2) What are the channels underlying this effect?; and 3) To what extent do the gains from retail FDI differ across the pre-existing income distribution? In answering these questions, the paper also makes two methodological contributions to the literature that focuses on quantifying the gains from trade and FDI. The first is that rather than imposing structure ex ante to limit the data requirements to a set of readily available cross-country moments, we instead exploit newly available and extremely de-

\footnotetext{
${ }^{1}$ Between 2000 and 2012, foreign affiliate sales of the 250 largest global retailers grew by more than 400 percent reaching 1 trillion USD (Deloitte, 2014), with much of the growth in developing countries-the developing country share of world inward retail FDI doubled to 25 percent since the 1990s and the stock grew more than twenty-fold (UNCTAD World Economic Report 2014). Over the same period, i.e. since 2000, the share of traditional retail in developing country grocery expenditures decreased from 80 to 57 percent (Bronnenberg and Ellickson, 2015).

${ }^{2}$ For example, it took India's Congress Party until 2012 to finally approve foreign entry into multi-brand retail. Several Indian states subsequently blocked foreign entry, and most recently the BJP government announced it would move back to an outright nationwide ban of foreign retailers.

${ }^{3}$ Figures based on developing country samples from the 2013 ILOSTAT Database (employment), 2012 UN National Accounts data (GDP), and the World Bank LSMS household consumption surveys from 2000-2010 (retail expenditures).
} 
tailed microdata that allow us to estimate a very general expression for the welfare gains from retail FDI. In particular, data on barcode-level consumer prices and consumption quantities, workerlevel incomes and store-level profits allow us to capture all major components of household welfare without shutting down any potential channels-such as gains from variety or pro-competitive effects on prices in domestic stores-ex ante. The second contribution is that, rather than relying on cross-sectional moments that may or may not capture the causal effects of integration, we propose an event study design to credibly identify the moments we feed into the welfare expression.

At the center of the analysis lies the construction of a new collection of microdata. We combine data on all foreign-owned supermarket locations and opening dates over the period 2002-2014 with five additional datasets: i) monthly store-level consumer prices at the barcode-equivalent level (e.g. a 16 pill package of Bayer Aspirin with $300 \mathrm{mg}$ dosage) from the confidential microdata of the Mexican CPI; ii) daily household-by-store level data on consumption quantities and prices at the barcode-equivalent level from the consumer panel of the Mexican operation of a large international market research company; iii) store-level revenues, costs and profits for the universe of urban retail establishments from two cross-sections of the confidential microdata of the Mexican retail census; iv) quarterly worker-level incomes by occupation and sector from Mexico's urban employment and occupation surveys; and v) household-level income shares by occupation and sector matched to consumption shares across products and store formats from Mexico's biannual income and expenditure surveys. ${ }^{4}$

The analysis proceeds in three steps. In Step 1, we write down a general expression for the effect of retail FDI on household welfare in the municipality of entry. We decompose the total effect into six distinct effects: three effects on household cost of living (the price index) and three effects on household nominal incomes. On the cost of living side, we distinguish between the effect on consumer prices at pre-existing domestic retailers (the pro-competitive price effect); the effect due to exit of domestic retailers (the pro-competitive exit effect); and the direct price index effect which encompasses all the consumer gains derived from being able to shop at the foreign store itself, including different prices for pre-existing products, new product variety as well as different store amenities. The nominal income effect comprises a retail labor income effect (from employment in either traditional or modern retail), a retail profits effect for domestic store owners, and an indirect effect on other sources of household income from non-retail sectors of the local economy.

In Step 2, we estimate the empirical moments required to quantify the six effects that underlie the total household gains from retail FDI. To tackle the pro-competitive price effect, we estimate how prices change in domestic stores in response to the first entry of a foreign supermarket in the municipality. The first empirical challenge is that the composition of goods and stores changes over time. To address this, we use the Mexican CPI microdata to construct a 12-year time series of monthly prices for barcode-equivalent products sold in a particular retail outlet in a particular municipality. The second empirical challenge is non-random entry of foreign retailers across municipalities and over time. We propose an event study design that allows us to transparently

\footnotetext{
${ }^{4}$ Note that we refer to all retail establishments as "stores" in this paper even though the data include all types of retail units (for example, street markets, convenience stores, and supermarkets).
} 
and non-parametrically test whether foreign retailers targeted store openings towards municipalities with pre-existing price trends. The store opening data suggest that, over our period of study, foreign retailers operated under the objective of rapidly establishing store presence across all of urban Mexico. If so, the timing of opening will be determined by the speed of obtaining zoning permits and building delays, and uncorrelated with location-specific changes in prices or incomes. We test this identifying assumption by estimating a full set of monthly treatment effects beginning in the years before the store opening event and continuing for several years after. In support of our assumption, we find no evidence of pre-trends in these monthly treatment effects.

While our data allow us to observe the consumer price changes within continuing domestic shopping outlets in order to estimate the pro-competitive price effect, the two remaining cost of living effects are more difficult to quantify. The issue is that the implicit changes in the price index that result from either the arrival of a new foreign store (the direct price index effect) or the exit of domestic stores (the pro-competitive exit effect) are inherently unobservable. To quantify the cost of living implications of these changes in the available consumer choice set, we require further assumptions about consumer demand to pin down 'virtual prices' - the price at which demand would be zero-for foreign stores before they entered and domestic stores after they exited.

To this end, we use two different approaches. Our preferred approach is an exact estimation of the cost of living effect under a multi-tier CES preference structure where, within a broad product group, consumers have asymmetric CES preferences over stores, or more precisely over store-level consumption aggregates. These aggregates are themselves optimal bundles chosen from the specific products available in each store. The direct price index effect under this approach requires information on the ex post household expenditure shares on foreign stores in combination with estimates of the elasticity of substitution across local stores (in both cases by household income group and product group). To obtain these estimates, we exploit the uncensored consumer panel microdata which contain prices and household consumption quantities at the barcode-equivalent level matched to individual retailer identities. For the supply-side variation needed to identify the elasticity of substitution, we exploit the fact that local prices in supermarket chains are driven, at least in part, by national and regional supply shocks and pricing rules.

This CES approach has several benefits. First, as shown by Anderson et al. (1992), these preferences generate the same demands as would be obtained from aggregating many consumers who make discrete choices over which store to shop in. Second, this approach has the appeal of being widely used in the trade literature starting with Feenstra (1994), in part because it yields a very parsimonious expression for the welfare gain from new products (or stores in our case). Third, the CES approach allows us to relate our results to the recent quantitative literature on the gains from trade as the expression for our direct price index effect is identical to the well known import share sufficient statistic for the gains from trade in Arkolakis et al. (2012) and extended to horizontal FDI by Ramondo and Rodriguez-Clare (2013).

While the assumption of CES preferences has its virtues, it also imposes a particular structure on household demand. As an alternative approach, we also estimate a first order approximation of the cost of living effect that is solely based on observable price changes due to foreign entry. The 
advantage of this alternative approach is that it yields a Paasche price index that approximates the consumer gains that arise from foreign store entry without imposing preference assumptions. The disadvantage is that, since this approach essentially assumes that the foreign stores were always present and simply lowered their prices at the time of entry, we are necessarily abstracting from any gains due to the new product and store variety provided by foreign stores or the fact they may provide different amenities to shoppers. For this reason, the difference between the direct price index effect under CES and the first order approach is also informative as it provides an approximate estimate of the proportion of the gains that come from these variety and amenity channels as opposed to lower prices on pre-existing products.

To estimate the effects on nominal household incomes, we construct a quarterly time series of individual income, occupation, sector and employment status using the Mexican employment and occupation surveys. The identification issues are similar to those we address in the price regressions, and we follow a similar event study approach. To capture the effects on retail profits for owners of local domestic stores, as well as the effects on store exit, we complement these data with the confidential microdata on store counts and profits from the Mexican retail census.

In Step 3, we combine the estimated effects on consumer prices, consumption quantities and nominal incomes from Step 2 with the theoretical framework in Step 1 in order to quantify the household welfare effects of foreign entry. To do so, we require pre-entry household consumption shares across various product groups and store types, as well as labor and business income shares from various occupations and sectors. We obtain this information from the Mexican income and expenditure surveys which allow us to estimate a predicted welfare change for each household in the sample depending on their particular work and consumption patterns (restricting attention to locations without a foreign store at the time of the survey).

We find that foreign supermarket entry causes large and significant welfare gains for the average household in the municipality of entry, equal to 6 percent of initial household income. The majority of this effect is driven by a significant reduction in the cost of living. While there is a 0.7 percent increase in the cost of living due to pro-competitive exit effects, this is more than compensated by a reduction of 1.6 percent due to pro-competitive effects on consumer prices charged by pre-existing domestic stores and a reduction of 5.5 percent due to the direct price index effect (i.e. foreign supermarkets offering cheaper prices, new varieties and different shopping amenities to consumers). ${ }^{5}$ The relatively large direct effect is consistent with raw moments in the data that we present as motivating evidence: foreign retailers charge on average 12 percent lower prices for an identical barcode in the same location and time, offer five times the number of products compared to modern domestic stores, and after entering capture more than one third of total household retail spending on average. The first order approximation of the direct price index effect is 40 percent of the size of the CES estimate suggesting that just under half of the direct effect can be accounted for by the cheaper prices at foreign stores, with the remainder due to the additional

\footnotetext{
${ }^{5}$ Note that these price index changes refer to the entirety of household consumption, accounting for the fact that retail is on average half of household consumption during the estimation period. We show that non-retail prices do not respond to foreign retail entry.
} 
benefits from product and store variety and differences in foreign store amenities. The nominal income effects are small in comparison. We find no effect on average municipality-level household incomes or employment rates. We do, however, find evidence of store exit and adverse effects on domestic store profits, employment and labor incomes for workers in the traditional retail sector. While these adverse income effects are sizable, they affect only a fraction of households and so are swamped in the aggregate by reductions in the cost of living that benefit all households.

We also quantify the distribution of the gains from retail FDI. While, on average, all household income groups experience significant gains from foreign entry, the richest income groups gain about 50 percent more than the poorest. We find that the key driver is the fact that richest households substitute over 50 percent of their retail consumption to foreign stores, while the poorest substitute less than 15 percent. Since the elasticity of substitution is broadly similar for both income groups, these market share differences imply that wealthier households in Mexico value the consumption choices on offer at foreign stores significantly more than poorer ones (for example, due to the rich placing a higher value on foreign brands, high quality varieties and large pack sizes; or on store amenities such as parking, car accessibility, wide aisles, security and hygiene).

Finally, we ask to what extent the estimated welfare gains are specific to foreign supermarket entry (FDI), rather than being driven by the entry of modern store formats more generally. We do not find pro-competitive price effects or comparable direct price index effects when running identical specifications for the entry of domestic retailers with similar big box formats to the foreign entrants. We also find that the pro-competitive and direct price index effects of foreign entry are large and significant in locations with pre-existing domestic big box stores, as well as in those without. Together, these pieces of evidence suggest that the large consumer gains we estimate for Mexico are specific to retail FDI.

The paper closely relates to a small body of work that explores the economic consequences of foreign supermarkets in developing countries (Iacovone et al., 2015; Javorcik and Li, 2013). ${ }^{6}$ Relative to these papers that have focused on the spillover effects on domestic suppliers, this paper instead focuses on the consequences for consumers, workers and business owners located in the municipality where the foreign store entry occurs. To the best of our knowledge, this is the first paper to provide empirical evidence on these first order effects of retail globalization. We note that in order to do so convincingly, this paper's focus is on quantifying the effects of foreign retail entry on local household welfare within the municipality of entry. This focus allows us to credibly estimate impacts of foreign entry by comparing the municipality of entry to other locations that did not experience a foreign store opening in the same period. The limitation of such an approach is that it is silent on potentially interesting national level effects such as changes in manufacturing productivity that are absorbed by the time fixed effects in our empirical setting. Our work also relates to Lagakos (in press) who emphasizes the role of endogenous store format choices in explaining cross-country differences in retail sector TFP. Consistent with our finding of much larger gains for richer households, he finds that car ownership rates are significantly related to the

\footnotetext{
${ }^{6}$ Varela (2013) uses Walmart's local entry decisions in Mexico to estimate a structural model of diseconomies of scale in outlet expansion.
} 
adoption of modern store formats.

The paper is also closely related to the recent literature that estimates the gains from international integration for developing countries and the distribution of those gains (Porto, 2006 ; Goldberg and Pavcnik, 2007; Topalova, 2010; Atkin, 2013; Donaldson, in press; Faber, 2014; Fajgelbaum and Khandelwahl, 2014). Relative to the existing literature, we focus on the consequences of retail globalization, a channel of integration that has received relatively little attention. Methodologically, this paper differs in its careful empirical evaluation of all major components of household welfare and, in particular, the cost of living. Rather than relying on state level price deflators (e.g. Topalova, 2010; Deaton and Tarozzi, 2000), household consumption surveys combined with simulated price changes at the product group level (e.g. Porto, 2006; Deaton, 1989), or cross-country trade flows (e.g. Caron et al., 2012; Fajgelbaum and Khandelwal, 2014), this paper draws on price and consumption data at the level of individual households, barcode-equivalent products, and stores to provide a more precise and complete estimate of changes in the price index.

The paper is also related to the trade literature that estimates the gains from new imported product variety (Feenstra, 1994; Broda and Weinstein, 2006; Feenstra and Weinstein, in press). As well as drawing on these tools to estimate the cost of living gains from a new foreign retailer, the richness of our data allows us to directly observe foreign production shares in individual household consumption baskets at the level of disaggregated product groups. To the best of our knowledge, this is the first time such a match has been possible in order to quantify the consumer gains from international integration.

Finally, since Walmart de México is the major foreign retailer expanding during our estimation period, the paper relates to an extensive literature on the effects of Walmart in the United States (e.g. Basker 2005a; Jia 2008; Hausman and Leibtag 2007; and Holmes 2011). This paper offers two main innovations relative to the existing literature. First, studying a developing country allows us to shed light on the impact of exposing a largely traditional retail environment to what is arguably the world's technological frontier in retailing. Second, in contrast to the piecemeal approach adopted by the literature to date, this paper is the first to set up a unified empirical framework and estimate the effect of store entry on both cost of living and nominal incomes.

We structure the remainder of the paper as follows. Section 2 describes the Mexican context and provides motivating evidence. Section 3 presents the theoretical framework. Section 4 describes the six datasets. Section 5 presents the empirical strategy and estimation results. Section 6 draws on these estimation results in combination with estimates of household demand parameters to quantify the gains from retail FDI. Section 7 concludes.

\section{Background and Motivating Evidence}

\subsection{Background}

Prior to the 1980s, retail FDI into Mexico had to be approved on a case by case basis, and generally required a minimum of 51 percent Mexican ownership. These restrictions were gradually relaxed in the 1980s with foreign companies able to own up to 49 percent of a Mexican firm 
without explicit authorization. The 1993 FDI law allowed foreign firms full ownership rights and full freedom to repatriate profits. FDI was further protected with the NAFTA third-party dispute resolution mechanisms starting in 1994.

The first significant retail FDI into Mexico was the US company Safeway's purchase of 49 percent of Casa Ley (a regional retailer in Northern Mexico). More transformative was Walmart's decision to enter the Mexican market in the early 1990s as NAFTA was being negotiated. Walmart initially entered via a joint venture with the Mexican retailer Cifra, a chain from Mexico City with around 100 supermarket units at the time. In 1997, Walmart bought out Cifra and in 2000 changed the name of the company to Walmart de México (WALMEX). Unlike in the US, WALMEX focused heavily on food retail and targeted relatively affluent Mexican consumers. In the ensuing years, WALMEX and its multiple supermarket brands (Walmart, Sam's Club, Superama, Aurrera and Bodega Aurrera) became the largest retail chain in Mexico, as well as Mexico's largest employer with over 210,000 employees in January 2014. ${ }^{7}$ Although Walmart has been the most notable foreign entrant, two large French supermarket chains also entered and subsequently left the market (Auchan and Carrefour), while several other US firms continue to operate in Mexico (Costco, HEB, S-Mart, Smart and Final, and Waldos).

The expansion of Walmart and other foreign supermarket chains proceeded relatively slowly during the second half of the 1990s, predominantly serving the main metropolitan centers of Mexico. As depicted in Figure 1, the number of foreign supermarkets in Mexico expanded from 204 stores at the end of 1995 to 365 stores at the end of 2001. In both periods, the presence of foreign stores was heavily concentrated in a handful of major cities. Between 2002 and 2014, the sample period of our empirical analysis, the number of foreign retailers increased by a factor of four, from 365 to 1335 supermarkets. As is apparent in Figure 1, this period saw the expansion of foreign supermarkets beyond the large metropolitan areas of Mexico to smaller second and thirdtier cities. At the start of our sample in 2002, foreign stores were present in 96 of Mexico's 2438 municipalities. In contrast, by 2014 foreign stores were present in 461 municipalities.

\subsection{Motivating Evidence}

How do foreign-owned supermarkets differ from the domestic retailers that they compete with after they enter? In this subsection, we use the consumer panel microdata and the administrative records of the Mexican National Retail Association (ANTAD)—both described in Section 4 below-to document a set of stylized facts about how these stores differ.

Column 1 of Table 1 regresses log prices on a dummy for whether the store is foreign-owned and on municipality-by-barcode-by-month fixed effects. On average, foreign stores charge 12 percent lower prices for identical barcodes compared to domestic retailers in the same municipality during the same month. Interestingly, the sign of this difference is reversed and its magnitude doubles when we replace the municipality-by-barcode-by-month fixed effects by municipality-by-

\footnotetext{
${ }^{7}$ In this paper we only consider foreign entry in supermarket retail-which we take to be stores of 10,000 square feet and above- and so exclude smaller foreign-owned store formats such as convenience stores (in part due to data constraints, see footnote 18). When considering impacts on domestic stores, we include all types of store formats including supermarkets, traditional stores, and street markets.
} 
product-group-by-month fixed effects (column 2). Thus, foreign stores appear to offer a product mix that is significantly higher quality-where quality is proxied by price-and/or larger pack sizes within product groups (with anecdotal evidence suggesting both are true).

Foreign stores also sell a much larger set of product varieties. Column 3 uses the consumer panel data to regress the log of the count of different barcodes consumed by all households at a particular retailer in a particular year on a foreign store dummy and municipality-year fixed effects. We restrict this foreign-owned versus domestic comparison to modern store formats (i.e. supermarkets), leaving aside the smaller traditional domestic stores. Even with this restriction, a foreign-owned store offers approximately five times as many barcode products. Foreign stores offer not just more varieties, but also different varieties. Using data on purchases in the consumer panel, on average 60 percent of the barcode varieties offered by foreign stores in a given year and municipality are not offered by any domestic retailer (modern or traditional) in the locality. This difference in consumer choice is also clear when comparing the floor space records using the ANTAD data. Column 4 of Table 1 shows that the average foreign-owned store is approximately six times the size of a domestic retailer that is also a member of ANTAD.

Finally, there are a number of differences in the shopping amenities-the store's environment, location, etc.- offered by foreign-owned supermarkets compared to domestic retailers. In terms of positive amenities, foreign-owned supermarkets are typically more hygenic, offer greater security, more parking spaces, better car accessibility, and display and organize their products more attractively. In addition, households may value American or European supermarket brands more than domestic ones for aspirational reasons. In terms of negative amenities, foreign-owned stores tend to be located farther away from the town center due to both their larger size and their later entry into the market. Given significant differences in car ownership rates across the Mexican income distribution as well as potential differences in proximity to supermarkets across rich and poor neighborhoods, this differential accessibility will play an important role when estimating heterogeneity in the gains from foreign entry. In the theoretical framework that follows, a revealed preference approach captures these different amenities through income and product-group specific taste shifters across retailers that generate observable differences in the post-entry market shares of foreign stores.

To summarize, foreign stores differ substantially on a number of key dimensions: they charge lower prices, offer higher quality products and larger pack sizes, sell a much larger variety of products, and offer a different set of amenities. The size of these differences is substantial, certainly compared with the differences between big box stores and pre-existing retailers in the US (e.g. Hausman and Leibtag, 2007, see further discussion in Section 6.4.2). Such differences come in part from the fact that these foreign retailers pioneered the use of big box store formats, regional distribution centers, cutting edge logistics such as cold-chains for fresh products, and lean global supply chains (Biles, 2008). Essentially, our empirical setting captures the entry of global retail chains at the world technological frontier in retailing into local retail markets that are largely dominated by traditional store formats, street markets, and small regional supermarket chains. 


\section{Theoretical Framework}

In this section, we derive a general expression for assessing the impact of foreign supermarket entry on local household welfare as a function of various observable moments in our rich collection of microdata. In order to calculate the change in welfare due to the entry of a foreign supermarket we consider the compensating variation for household $h^{8}$ the change in exogenous income required to maintain utility when a foreign retailer arrives between period 1 and period 0 , with periods denoted by superscripts:

$$
C V_{h}=\underbrace{\left[e\left(\mathbf{P}^{1}, u_{h}^{0}\right)-e\left(\mathbf{P}^{0}, u_{h}^{0}\right)\right]}_{\text {Cost of living effect }(C L E)}-\underbrace{\left[y_{h}^{1}-y_{h}^{0}\right]}_{\text {Nominal income effect }(I E)}
$$

where $\mathbf{P}^{t}$ is the vector of prices faced by the household in period $t, u_{h}^{t}$ is the household's utility and $y_{h}^{t}$ is its nominal income (and where, for notational parsimony, changes between periods 0 and 1 denote the causal changes induced by foreign retail entry).

The first term is the cost of living effect, the welfare change due to the price changes induced by the arrival of the foreign retailer. The second term is the nominal income effect, the welfare change due to any changes in household income that result from the arrival of the foreign retailer. In the next two subsections we decompose the cost of living effect and nominal income effect into six distinct channels and express these as functions of observable moments in our microdata.

\subsection{Estimating the Cost of Living Effect}

While, at least in principle, the nominal income effect can be empirically estimated without imposing additional structure, this is not the case for the cost of living effect. While we can observe the vector of price changes $\mathbf{P}_{d c}^{1}-\mathbf{P}_{d c}^{0}$ for products sold in domestic continuing stores indexed by $d c$, i.e. those that are present in both periods, there are two sets of price changes that are inherently unobservable: the price changes $\mathbf{P}_{f}^{1}-\mathbf{P}_{f}^{0}$ at entering foreign retailers indexed by $f$ and the price changes $\mathbf{P}_{d x}^{1}-\mathbf{P}_{d x}^{0}$ at domestic exiting retailers indexed by $d x$. In particular, foreign retailers' prices are not observed prior to their entry, and exiting domestic retailers prices are not observed post exit. As first noted by Hicks (1940), we can replace these two unobserved price vectors with 'virtual' price vectors, the price vectors that would set demand for these stores equal to zero given the vector of consumer prices for other goods and services.

To see this more clearly, note that the cost of living effect in 1 can be re-written by dividing it into three quite distinct sub-components, one for each of the three sets of price changes above: a direct price index effect due to the implicit price changes at foreign stores (i.e. the gains enjoyed by consumers shopping at the new foreign store); a pro-competitive price effect due to continuing domestic retailers changing prices as a result of foreign retail entry; and a pro-competitive exit effect due to the implicit price changes at exiting domestic stores (i.e. the losses suffered by

\footnotetext{
${ }^{8}$ This approach follows earlier work by Hausman (1996) and Hausman and Leonard (2002).
} 
customers of closing stores):

$$
\begin{aligned}
C L E= & \underbrace{\left[e\left(\mathbf{P}_{f}^{1}, \mathbf{P}_{d c}^{1}, \mathbf{P}_{d x}^{1 *}, u_{h}^{0}\right)-e\left(\mathbf{P}_{f}^{1 *}, \mathbf{P}_{d c}^{1}, \mathbf{P}_{d x}^{1 *}, u_{h}^{0}\right)\right]}_{(1) \text { Direct price-index effect }(D E)}+ \\
& \underbrace{\left[e\left(\mathbf{P}_{f}^{1 *}, \mathbf{P}_{d c}^{1}, \mathbf{P}_{d x}^{1 *}, u_{h}^{0}\right)-e\left(\mathbf{P}_{f}^{0 *}, \mathbf{P}_{d c}^{0}, \mathbf{P}_{d x}^{0 *}, u_{h}^{0}\right)\right]}+\underbrace{\left[e\left(\mathbf{P}_{f}^{0 *}, \mathbf{P}_{d c}^{0}, \mathbf{P}_{d x}^{0 *}, u_{h}^{0}\right)-e\left(\mathbf{P}_{f}^{0 *}, \mathbf{P}_{d c}^{0}, \mathbf{P}_{d x}^{0}, u_{h}^{0}\right)\right]}
\end{aligned}
$$

(2) Pro-competitive price effect $(P P)$

(3) Pro-competitive exit effect $(P X)$

where asterisks denote virtual prices: $\mathbf{P}_{f}^{0 *}$ and $\mathbf{P}_{f}^{1 *}$ are pre- and post-entry prices in foreign stores that would set demand equal to zero, while $\mathbf{P}_{d x}^{0 *}$ and $\mathbf{P}_{d x}^{1 *}$ are the same for domestic exiting stores. Since virtual prices are inherently unobservable they must be estimated, which requires a demand function or at least an approximation to one. Below we propose two approaches: an exact estimation under CES demand and a first order approximation.

Exact Estimation under CES Demand We propose a three-tier demand system. In the upper tier there are Cobb-Douglas preferences over product groups $g \in G$ (e.g. beverages), in the middle tier there are asymmetric CES preferences over local retailers selling that product group $s \in S$ (e.g. Walmex, a foreign retailer; Soriana, a domestic retailer in modern retail; or a mom-and-pop store in the traditional retail sector), and in the final tier there are preferences over the individual products within the product groups $b \in B_{g}$ (e.g. a product such as a $330 \mathrm{ml}$ Coca Cola can) that we can leave unspecified for now:

$$
\begin{aligned}
U_{h} & =\prod_{g \in G}\left[Q_{g h}\right]^{\alpha_{g h}} \\
Q_{g h} & =\left(\sum_{s \in S_{g}} \beta_{g s h} q_{g s h}^{\frac{\eta_{g h}-1}{\eta_{g h}}}\right)^{\frac{\eta_{g h}}{\eta_{g h}-1}}
\end{aligned}
$$

where $\alpha_{g h}$ and $\beta_{g s h}$ are (potentially household- or income-group-specific) preference parameters that are fixed across periods. $Q_{g h}$ and $q_{g s h}$ are product-group and store-product-group consumption aggregates with associated price indices $P_{g h}$ and $r_{g s h}$ respectively, and $\eta_{g h}$ is the elasticity of substitution across local retail outlets. ${ }^{9}$ For each broad product group, consumers choose how much to spend at different stores based on the store-level price index $r_{g s h}$ (which itself depends on the products they anticipate buying in each store given its product mix and product-level prices).

This structure seems reasonable given that stores often specialize in certain product groups and, at least within a quarter, consumers often shop at several stores and choose different sets of products in each store. While the demand system is homothetic, we capture potential heterogeneity across the income distribution by allowing households of different incomes to differ in their expenditure shares across product groups $\left(\alpha_{g h}\right)$, their preferences for consumption bundles at different stores within those product groups $\left(\beta_{g s h}\right.$ and the preference parameters that generate $\left.q_{g s h}\right)$,

\footnotetext{
${ }^{9}$ This structure imposes that the elasticity of substitution between two modern retail stores is the same as across a modern and traditional store. We later explore the sensitivity of our estimates to relaxing this assumption by placing modern and traditional stores in different nests.
} 
as well as their elasticity of substitution across local stores $\left(\eta_{g h}\right){ }^{10}$

This approach has several advantages. First, as shown by Anderson et al. (1992), these preferences generate the same demands as would be obtained from aggregating many consumers who make discrete choices over which store to shop in. This mapping is appealing, particularly since in estimating price elasticities our unit of observation will be household income groups (observed separately for each location, period and product group).

Second, it has the appeal of being widely used in the trade literature starting with Feenstra (1994), in part because it yields a very parsimonious expression for the welfare gains from new products (or stores in our case). ${ }^{11}$ Building on Feenstra (1994), the following expression provides the exact proportional cost of living effect under this demand system:

$$
\frac{C L E}{e\left(\mathbf{P}_{f}^{0 *}, \mathbf{P}_{d c^{\prime}}^{0}, \mathbf{P}_{d x^{\prime}}^{0}, u_{h}^{0}\right)}=\frac{e\left(\mathbf{P}_{f}^{1}, \mathbf{P}_{d c^{\prime}}^{1} \mathbf{P}_{d x}^{1 *}, u_{h}^{0}\right)}{e\left(\mathbf{P}_{f}^{0 *}, \mathbf{P}_{d c^{\prime}}^{0}, \mathbf{P}_{d x^{\prime}}^{0}, u_{h}^{0}\right)}-1=\prod_{g \in G}\left(\left(\frac{\sum_{s \in S_{g}^{d c}} \phi_{g s h}^{1}}{\sum_{s \in S_{g}^{d c}} \phi_{g s h}^{0}}\right)^{\frac{1}{\eta_{g h}-1}} \prod_{s \in S_{g}^{d c}}\left(\frac{r_{g s h}^{1}}{r_{g s h}^{0}}\right)^{\omega_{g s h}}\right)^{\alpha_{g h}}-1
$$

where $S_{g}^{d c}$ denotes the set of continuing domestic retailers within product group $g$, $\phi_{g s h}^{t}=r_{g s h}^{t} q_{g s h}^{t} / \sum_{s \in S_{g}} r_{g s h}^{t} q_{g s h}^{t}$ is the expenditure share for a particular retailer in product group $g$, and the $\omega_{g s h} \mathrm{~s}$ are ideal log-change weights. ${ }^{12}$

For each product group $g$, the expression has two components. The $\prod_{s \in S_{g}^{d c}}\left(\frac{r_{g s h}^{1}}{r_{g s h}^{0}}\right)_{g s h}$ term is a Sato-Vartia (i.e. CES) price-index for price changes in continuing domestic stores that forms the pro-competitive price effect. ${ }^{13}$ The price terms $r_{g s h}^{t}$ are themselves price indices of product-specific prices $p_{g s b}^{t}$ within domestic continuing stores which, in principle, could also account for new product varieties using the same methodology. Empirically, we find no evidence of such effects in response to foreign retail arrival, and so abstract from this possibility in the exposition. ${ }^{14}$ While we name these price changes pro-competitive, they may derive from either reductions in markups or increases in productivity at domestic stores (distinctions that do not matter on the cost-of-living side but would generate different magnitudes of profit and income effects that we capture from observed changes on the nominal income side).

The $\left(\frac{\sum_{s \in S_{g}^{d c}} \phi_{g s h}^{1}}{\sum_{s \in S_{g}^{d c}} \phi_{g s h}^{0}}\right)^{\frac{1}{\eta_{g h}-1}}$ term captures the gains to customers of the foreign store in the numerator, the direct price index effect, and domestic store exit in the denominator, the pro-competitive exit effect.

\footnotetext{
${ }^{10}$ While convenient for empirical tractability, this ad hoc treatment of non-homotheticity shuts down a second-order price index effect. Large first-order effects of foreign entry on incomes may push some households across income groups and thereby change their preference parameters as defined above. Since we will allow preferences to differ across seven broad income groups, it is reasonable to think that few households are shifted in this manner.

${ }^{11}$ Note that, for example, a translog specification as in Feenstra and Weinstein (in press) requires knowledge of the causal effect of foreign entry on Herfindahl indices of the local retail market.

${ }^{12}$ In particular, $\omega_{g s h}=\left(\frac{\tilde{\phi}_{g s h}^{1}-\tilde{\phi}_{g s h}^{0}}{\ln \tilde{\phi}_{g s h}^{1}-\ln \tilde{\phi}_{g s h}^{0}}\right) / \sum_{s^{d c} \in S_{g}^{d c}}\left(\frac{\tilde{\phi}_{g s h}^{1}-\tilde{\phi}_{g s h}^{0}}{\ln \tilde{\phi}_{g s h}^{1}-\ln \tilde{\phi}_{g s h}^{0}}\right)$, which in turn contain expenditure shares of different retailers within product groups where the shares consider only expenditure at continuing retailers $\tilde{\phi}_{g s h}^{t}=r_{g s h}^{t} q_{g s h}^{t} / \sum_{s \in S_{g}^{d c}} r_{g s h}^{t} q_{g s h}^{t}$.

${ }^{13}$ Notice that the assumption of CES preferences does not imply the absence of pro-competitive effects as we do not impose additional assumptions about market structure (e.g. monopolistic competition).

${ }^{14}$ In particular, we find no evidence in the CPI microdata that foreign retail entry increases the propensity for product additions or replacements among domestic retailers. We report these regressions in online appendix Table A.1.
} 
For expositional purposes, consider the simple case where there are no pro-competitive effects (such as when firms are monopolistically competitive as in Krugman, 1980):

$$
\frac{C L E}{e\left(\mathbf{P}_{f}^{0 *}, \mathbf{P}_{d c^{\prime}}^{0}, \mathbf{P}_{d x}^{0}, u_{h}^{0}\right)}=\prod_{g \in G}\left(\left(\sum_{s \in S_{g}^{d c}} \phi_{g s h}^{1}\right)^{\frac{1}{\eta_{g h}-1}}\right)^{\alpha_{g h}}-1 .
$$

The welfare gain from a new store is a function of the market share of that store post entry and the elasticity of substitution across stores. The revealed preference nature of this approach is clear. If consumers greatly value the arrival of the new store-be it because the store offers low prices $p_{g s b^{\prime}}^{1}$ more product variety that reduces $r_{g s h}^{1}$ or better amenities captured by a large $\beta_{g s h}$-the market share is higher and the welfare gain greater. Hence, these market share changes capture all the potential benefits of shopping in foreign stores outlined in the motivating evidence of Section 2. How much greater depends on the elasticity of substitution. Large foreign market shares will imply small welfare changes if consumers have a high elasticity of substitution between stores, and large welfare changes if they are inelastic. A similar logic applies to the exit of domestic stores where a large period 0 market share means large welfare losses, again tempered by the elasticity of substitution. ${ }^{15}$

Equation 6 also makes clear a third benefit of this approach. The CES assumption allows us to relate our estimation results to the recent quantitative literature on the gains from trade and FDI since the expression of the cost of living effect in the absence of pro-competitive effects is identical to the well known import share sufficient statistic of Arkolakis et al. (2012). Thus, our welfare expression allows us to shed light on the importance of pro-competitive effects, to separately estimate effects on nominal incomes and household cost of living, and to quantify the distribution of the gains from FDI through the household-level heterogeneity we incorporate.

In our quantification, we decompose the welfare gains into their constituent parts. Accordingly, we add and subtract terms to equation 5 to separate the cost of living effect into the direct price index effect and the two pro-competitive effects described in the preceding paragraphs:

$\frac{C L E}{e\left(\mathbf{P}_{f}^{0 *}, \mathbf{P}_{d c^{\prime}}^{0}, \mathbf{P}_{d x}^{0}, u_{h}^{0}\right)}=\underbrace{\left[\prod_{g \in G}\left(\left(\frac{\sum_{s \in S_{g}^{d c}} \phi_{g s h}^{1}}{\sum_{s \in S_{g}^{d c}} \phi_{g s h}^{0}}\right)^{\frac{1}{\eta_{g h}-1}} \prod_{s \in S_{g}^{d c}}\left(\frac{r_{g s h}^{1}}{r_{g s h}^{0}}\right)^{\omega_{g s h}}\right)^{\alpha_{g h}}-\prod_{g \in G}\left(\left(\frac{1}{\sum_{s \in S_{g}^{d c}} \phi_{g s h}^{0}}\right)^{\frac{1}{\eta_{g h}-1}} \prod_{s \in S_{g}^{d c}}\left(\frac{r_{g s h}^{1}}{r_{g s h}^{0}}\right)^{\omega_{g s h}}\right)^{\alpha_{g h}}\right]}$

(1) Direct price-index effect $(D E)$

$+\underbrace{\left[\prod_{g \in G}\left(\prod_{s \in S_{g}^{d c}}\left(\frac{r_{g s h}^{1}}{r_{g s h}^{0}}\right)^{\omega_{g s h}}\right)^{\alpha_{g h}}-1\right]}+\underbrace{\left[\prod_{g \in G}\left(\left(\frac{1}{\sum_{s \in S_{g}^{d c}} \phi_{g s h}^{0}}\right)^{\frac{1}{\eta_{g h}-1}} \prod_{s \in S_{g}^{d c}}\left(\frac{r_{g s h}^{1}}{r_{g s h}^{0}}\right)^{\omega_{g s h}}\right)^{\alpha_{g h}}-\prod_{g \in G}\left(\prod_{s \in S_{g}^{d c}}\left(\frac{r_{g s h}^{1}}{r_{g s h}^{0}}\right)^{\omega_{g s h}}\right)^{\alpha_{g h}}\right]}$

(2) Pro-competitive price effect $(P P)$

(3) Pro-competitive exit effect $(P X)$

\footnotetext{
${ }^{15}$ We note that such a revealed preference approach would not capture cultural losses from the closure of traditional stores to the extent that those are not internalized by consumers. Similarly, such an approach only captures the health consequences of changes in shopping behavior that are internalized by consumers.
} 
First Order Approach Using Observed Price Differences While the assumption of CES preferences has its virtues, it also imposes a particular structure on household demands. As an alternative approach, we exploit the richness of the store price data to estimate a first order approximation of the cost of living effect that is solely based on observable price changes due to foreign entry.

We take a first-order Taylor expansion of the expenditure function around period 1 prices and apply Shephard's lemma. Focusing on the sales and price changes in the set of domestic stores continuously selling product $b$ across both periods (for which we can observe price changes) provides us with the pro-competitive price effect:

$$
P P^{\prime} \approx \sum_{b} \sum_{s \in S_{b}^{d c}}\left(q_{b s h}^{1}\left(p_{b s}^{1}-p_{b s}^{0}\right)\right)
$$

where $q_{b s h}^{t}$ is the quantity consumed of product $b$ in store $s$ by household $h$ in period $t$ and $S_{b}^{d c}$ is the set of domestic stores continuously selling product $b$ across both periods. Rewriting the $P P^{\prime}$ in proportional terms:

$$
\frac{P P^{\prime}}{e\left(\mathbf{P}_{f}^{1}, \mathbf{P}_{d c^{\prime}}^{1}, \mathbf{P}_{d x}^{1 *}, u_{h}^{0}\right)} \approx \sum_{b} \sum_{s \in S_{b}^{d c}}\left(\phi_{b s h}^{1}\left(\frac{p_{b s}^{1}-p_{b s}^{0}}{p_{b s}^{1}}\right)\right)
$$

where $\phi_{b s h}^{1}$ is the household expenditure share spent on the product in period 1. To a first order approximation, the pro-competitive effect is simply a Paasche price index of the product-level price changes at continuing domestic stores due to foreign entry multiplied by the period 1 share of total expenditure captured by that store-product pair. Since the first order approach explicitly assumes no stores exited between periods 0 and 1, there are no separate exit and price effects.

For the direct price index effect, we focus on the sales and price changes at foreign stores in the Taylor expansion around period 1 prices:

$$
\frac{D E^{\prime}}{e\left(\mathbf{P}_{f}^{1}, \mathbf{P}_{d c^{\prime}}^{1} \mathbf{P}_{d x}^{1 *}, u_{h}^{0}\right)} \approx \sum_{b} \sum_{s \in S_{b}^{f}}\left(\phi_{b s h}^{1}\left(\frac{p_{b f}^{1}-p_{b d s}^{0}}{p_{b f}^{1}}\right)\right) .
$$

where $S_{b}^{f}$ is the set of foreign stores selling product $b$ in period 1 . Hence, the direct price index effect corresponds to a Paasche price index of the product-level price differences between foreign stores in period $1, p_{b f}^{1}$, and domestic stores in period $0, p_{b d s}^{0}$, multiplied by the period 1 share of total expenditure captured by foreign stores for that particular product. Essentially, this approach is equivalent to assuming the foreign stores were always present and always selling the same set of products and providing the same amenities, but in period 0 they charged the pre-entry prices charged by domestic stores. In this sense, we abstract from unobserved gains to product variety, store variety and amenity and solely focus on observable price changes.

The benefits of this approach are clear. It yields a transparent Paasche price index that approximates the consumer gains from foreign entry purely based on observable moments in the price microdata and without the need to impose a particular functional form on consumer preferences. Essentially, we are multiplying the post-entry foreign market share by the observed price differences between foreign and domestic stores for the direct price index effect, and the post-entry do- 
mestic market share by the price changes at domestic stores for the pro-competitive effect. The disadvantages are equally clear. Since we implicitly assume the foreign stores were always present, we miss any gains that arise from the existence of another store as well as the greater product varietyand the amenities provided by foreign stores. Given that these variety and amenity differences are substantial, a fact we highlighted in Section 2, we prefer the exact approach under CES for our baseline estimates.

Finally, reporting both approaches provides an additional benefit. For the reasons discussed above, the difference between the direct price index effect under CES (the first term in equation 7) and the direct price index effect under the first order approach (equation 10) provides us with an approximate estimate of the proportion of the direct consumer gains from the new foreign store that come from new product variety, new store variety and different store amenities, as opposed to from lower prices alone. ${ }^{16}$

\subsection{Estimating the Nominal Income Effect}

The nominal income effect in equation 1 can also be separated into distinct sub-components. We divide the household's income sources into three groups: Households obtain labor income from working in retail, business income from owning and operating their own retail outlet, and both labor and business income from other sectors (i.e. non-retail) indexed by $o$. For labor and business incomes in retail we additionally distinguish between the traditional retail segment (mom and pop stores, street stalls etc.) indexed by $\tau$ and modern store formats (supermarkets, chain stores etc.) indexed by $\mu$ :

$$
y_{h}=\sum_{i \in\{\tau, \mu\}} l_{i h}+\sum_{i \in\{\tau, \mu\}} \pi_{i h}+\sum_{i \in\{0\}}\left(l_{i h}+\pi_{i h}\right)
$$

where $l_{i h}$ and $\pi_{h i}$ denote labor income and business income from sector $i$, respectively. Taking a first difference and dividing through by initial income, we obtain three nominal income effects:

$$
\frac{I E}{e\left(\mathbf{P}_{f}^{0 *}, \mathbf{P}_{d c^{\prime}}^{0} \mathbf{P}_{d x^{\prime}}^{0}, u_{h}^{0}\right)} \approx-\underbrace{\sum_{i \in\{\tau, \mu\}}\left[\theta_{i l h}^{0}\left(\frac{l_{i h}^{1}-l_{i h}^{0}}{l_{i h}^{0}}\right)\right]}
$$

(4) Retail labor income effect

$$
-\underbrace{\sum_{i \in\{\tau, \mu\}}\left[\theta_{i \pi h}^{0}\left(\frac{\pi_{i h}^{1}-\pi_{i h}^{i 0}}{\pi_{i h}^{0}}\right)\right]}-\underbrace{\sum_{i \in\{0\}}\left[\theta_{i l h}^{0}\left(\frac{l_{i h}^{1}-l_{i h}^{0}}{l_{i h}^{0}}\right)+\theta_{i \pi h}^{0}\left(\frac{\pi_{i h}^{1}-\pi_{i h}^{i 0}}{\pi_{i h}^{0}}\right)\right]}
$$

(5) Retail profit effect

(6) Other income effect

\footnotetext{
${ }^{16}$ The comparison is approximate since the first-order direct price index effect (that is only due to price gaps) is biased upwards - the Paasche weights ignore the substitution away from foreign stores if they charged domestic-store prices in the pre-entry period. We can avoid this bias by using the CES preference structure described above along with knowledge of the $\eta_{g h}$ parameters to estimate counterfactual first-period expenditure weights that take account of this substitution and then calculate an unbiased Sato-Vartia price index. In contrast, the advantage of the Paasche approach is that we do not require unobserved counterfactual market shares. Given this trade-off, we will report both approaches. Note that using observed foreign-store budget shares pre and post entry to construct a price index using observed price gaps would neither estimate the full cost of living effect (that requires us to compute virtual prices consistent with zero consumption pre entry), nor the effect of price changes alone (which requires counterfactual pre-entry budget shares as we discuss above).
} 
where $\theta_{i l h}^{0}$ and $\theta_{i \pi h}^{0}$ are the period 0 shares of total income that come from labor and business income in sector $i$, respectively.

Foreign retail entry may change labor incomes in both the traditional and modern retail sector, the retail labor income effect. Foreign entry may also affect the profits of domestic store owners, the retail profit effect. Finally, foreign entry may give rise to general equilibrium effects on labor and business incomes in other sectors of the local economy or affect incomes for households producing goods sold at local retailers, the other income effect. Each of these nominal income effects can occur both at the intensive and extensive margin. At the intensive margin, foreign entry can affect earnings of individuals who remain active in a given sector and occupation. At the extensive margin, foreign entry may lead households to reallocate across sectors and occupations. ${ }^{17}$

\section{Data}

The theoretical framework outlined in the previous section allows us to express the gains from foreign retail entry in equations 7 and 12 as a function of: i) causal effects on consumer prices, consumption quantities and household nominal incomes, ii) household demand parameters that govern the elasticity of substitution across retail outlets, and iii) household expenditure shares across product groups and store types within product groups, and income shares across sectors and occupations. This section describes the data sources we draw on to obtain these estimates. Online appendix Table A.2 contains descriptive statistics for the key variables in each dataset.

Store Opening Dates and Locations Our main regressor of interest is the first entry of a foreignowned supermarket in a municipality. To generate this variable, we obtain data on store locations and dates of opening from Mexico's national association of retail businesses ANTAD (Asociación Nacional de Tiendas de Autoservicio y Departamentales). All major national and regional retailers in Mexico are part of ANTAD comprising more than 34,000 retail units with close to 25 million square meters of retail space. Between 2002 and 2006, ANTAD collected detailed data from its members about the location and date of opening of every establishment. For subsequent periods we obtained foreign-owned supermarket openings directly from retailers' annual reports. If these were not available, we used their store locations as of March 2014 (listed on their websites) and then obtained opening dates from local newspaper coverage of store openings or by calling them. ${ }^{18}$ Throughout the paper, we define a retailer as foreign if 49 percent or more of the firm is held by a foreign retailer (the cap on foreign ownership before FDI liberalization in 1994). With the exception of Safeway that owns 49 percent of Casa Ley, all foreign retailers own majority stakes.

\footnotetext{
${ }^{17}$ To see this more clearly, we can decompose each of the three terms in expression 12 into three mutually exclusive margins; an intensive margin (e.g. in the case of labor income, $\theta_{i l h}^{0}\left(\frac{l_{i h}^{1}-l_{i h}^{0}}{l_{i h}^{0}}\right)$ if $l_{i h}^{0}>0$ and $\left.l_{i h}^{1}>0\right)$, a job loss margin (e.g. $\theta_{i l h}^{0}(-1)$ if $l_{i h}^{0}>0$ and $\left.l_{i h}^{1}=0\right)$, and a new jobs margin (e.g. $\left(\frac{l_{i h}^{1}}{y_{h}^{0}}\right)$ if $l_{i h}^{0}=0$ and $\left.l_{i h}^{1}>0\right)$. Note that we do not attempt to value changes in household leisure time, which we implicitly assume to be fixed.

${ }^{18}$ Our focus on foreign supermarket entry comes in part from the fact that this strategy was not feasible for smaller store formats, where the number of units per chain goes from hundreds (supermarkets) to thousands (convenience stores). In the 2002-2006 data, smaller-format foreign entry patterns are uncorrelated with foreign entry in supermarket retail. We also thank Mauricio Varela for providing data on Walmart store openings between 2002 and 2006 (when Walmart was not a member of ANTAD).
} 
In our empirical work it will be important to control for trends using comparable municipalities. Since foreign retailers rarely open in rural areas or small towns, we exclude these from our analysis by restricting attention to the 608 municipalities with at least one chain store (i.e. ANTAD member) in at least one year of our ANTAD data. Unsurprisingly, these municipalities are larger (a median population of 63,000 compared to a median of 8,000 for the remaining 1,848 municipalities) and exclusively urban. By the end of our sample in 2014, 76 percent of these sample municipalities contain a foreign retailer whereas only 16 percent did at the start of our sample in 2002.

In both the theoretical framework and empirical analysis, we distinguish between traditional and modern retail store formats. The distinction that we can observe most consistently across datasets is between mom and pop stores, street stalls, and independent specialist stores (e.g. butchers and hardware stores) on the traditional side; and supermarkets, chain specialist and convenience stores, and department stores on the modern side.

CPI Microdata To estimate the pro-competitive price effect, we rely on the monthly microdata that are used to construct the Mexican CPI. These data consist of retail price quotes collected by Mexico's national statistics agency INEGI (since July 2011) and Mexico's Central Bank (prior to July 2011). Every month INEGI enumerators obtain price quotes (inclusive of any promotions/sales and value added tax) for around 83,500 items covering 315 product categories in 141 urban municipalities. These individual price quotes are made publicly available on a monthly basis in an official government gazette. ${ }^{19}$ Additional details are provided in online appendix B.1. Because computing the CPI requires prices of identical products in the same retail outlet over time, these data are ideally suited to estimate price changes at surviving domestic retail establishments.

In addition to these publically accessible data, we also obtain access to the confidential data columns of the Mexican CPI. These crucially allow us to observe the municipality in which the price quote was taken, as well as store format type and retailer name. The latter information allows us to explore heterogeneity across traditional and modern stores as well as to remove foreign stores from the estimation of the pro-competitive price effect.

As the price sampling is designed to be representative of Mexican household consumption, these data have a number of useful features. First, the price quotes are collected from not only modern stores but also traditional stores (including street stalls). Second, the quotes cover not just retail product groups but also services such as health, education, housing and transport. Third, within a given product group, the products and stores sampled are chosen to match the consumption patterns of urban households in the ENIGH consumption surveys discussed below.

When comparing prices of the same product over time, we will focus on the subset of goods which are identified by their brand, pack-size and variety (e.g. fresh whole milk Alpura brand 1 liter carton). These barcode-equivalent products comprise more than one third of all price quotes in the CPI microdata, and product groups with barcode information account for on average 40 percent of household retail expenditure. Focusing on these products allows us to ensure there are no changes in product characteristics over time that may confound estimates of the pro-competitive

\footnotetext{
${ }^{19}$ We thank Etienne Gagnon for access to the data he assembled directly from the gazette.
} 
price effect. The final estimation sample consists of roughly 3.3 million monthly store-price observations in 120 product categories across 76 urban municipalities over the period 2002-2014. In our main analysis, we assume that the price changes due to foreign entry that we estimate from barcode-equivelent products for the reasons outlined above are also applicable to non barcodeequivalent products within the same product group. We also report robustness results where we make alternative assumptions about price changes for non barcode-equivalent items.

Consumer Panel Microdata The estimation of the direct price index effect requires data on the post-entry retail market shares of foreign supermarkets as well as estimates of the elasticity of substitution across local stores (both across product groups and across different levels of household income). For this purpose, we use the consumer panel microdata of a large international market research company. ${ }^{20}$ Their Mexican consumer panel covers the years 2011-2014 and is similar in nature to the home scanner data that market research companies collect in the US. The panel consists of approximately 6,000 urban households classified by seven income groups and distributed across 156 municipalities. Households are visited biweekly to obtain complete consumption diary information about all products purchased by the household. As with the CPI data, these data are at the barcode-equivalent level with enumerators carefully noting the brand, variety and pack size. The household sample is updated annually to be representative of all cities over 50,000 once the provided survey weights are taken into account. These microdata comprise roughly 24 million transaction-level observations between January 2011 and June 2014. Importantly, unlike the academic-use versions of similar US datasets, we have retailer identities for every transaction in a household's consumption basket. Thus, these data are ideally suited to observe retailer market shares by household, as well as to estimate elasticities of substitution across stores.

Retail Census Microdata For the purpose of estimating the effect of foreign entry on retail profits and domestic store exit we use the confidential version of the Economic Census microdata for the years 2003 and 2008 (Censos Económicos 2004 and 2009) from INEGI. The Economic Census records establishment level information for the universe of urban retail establishments. The restricted access version of the data we use allows us to separately observe the number of modern retail stores (supermarkets, chain stores and department stores) and traditional retail stores (the remaining stores), as well as store-level revenues and costs from which we compute profits. Additional details are provided in online appendix B.2. The resulting dataset contains 1.3 million retail establishments across our 608 sample municipalities in 2003 and 1.5 million in 2008.

Employment and Occupation Survey Microdata To estimate the effect of foreign entry on nominal incomes and employment, we require high frequency survey data. To this end, we use INEGI's National Urban Employment Surveys between 2002 and 2005 and its successor, the National Employment and Occupation Surveys, between 2005 and 2012. These surveys are rotating panels of households in which a given household is followed over 5 quarters. The survey tracks sector, occupation and income in a similar manner to the ENIGH dataset described below but has the

\footnotetext{
${ }^{20}$ These data were made available to us through an academic collaboration with their Mexico City office under the condition that the firm's name remained anonymous.
} 
advantage of a much larger sample size: every quarter more than 100,000 individual residences are surveyed with the details of each working-age household member recorded. The resulting sample comprises roughly 5 million person-quarter observations across 273 urban municipalities.

Household Income and Expenditure Survey Microdata In our quantification exercise, in order to calculate welfare effects across the income distribution we need to know the expenditure shares of households across various product groups matched to income shares from various occupations and sectors. For this purpose, we use the Mexican National Income and Expenditure Surveys (ENIGH), which are administered biannually by INEGI between 2006 and 2012. These data allow us to observe the income and sources of income for each household as well as their expenditure shares across all retail and non-retail product groups. Additionally-starting in 2006, hence our use of only the more recent rounds - these data record for each product group the proportions sold at different types of stores (supermarket, street stall, etc.). Given the welfare expression derived in the previous section, we require pre-entry income and expenditure shares and so we restrict attention to the 12,293 households residing in 240 urban municipalities that had not yet experienced foreign retail entry at the time the ENIGH survey was conducted. We match the product modules covered by the consumer panel data above to the household income and expenditure surveys at the level of 12 broad product groups. As discussed above, the match between ENIGH and the CPI price data is straight-forward, as both are based on the same product groups.

\section{Estimating the Effects of Foreign Retail Entry}

This section draws on the microdata described in the previous section to estimate the effect of foreign retail entry on local consumer prices, retail market shares, store exit, household labor and business incomes, and employment. As well as being of interest in their own right, these estimates enter into our cost of living and nominal income expressions, equations 7 and 12, and hence form the basis of the quantification exercise in Section 6. We focus on the effect of the first foreign store entry as we wish to capture the impact of both the initial entry and any subsequent foreign entry induced by the initial entry. In practice, this choice makes little difference as the vast majority of urban municipalities-more than 85 percent of entry events in our sample-receive just one foreign store during our estimation period that ends in 2014.

\subsection{Effect on Consumer Prices}

\subsubsection{Effect on Consumer Prices in Domestic Retail Stores}

Empirical Strategy To estimate the effect of foreign supermarket entry on consumer prices in domestic retail stores, we combine information on the universe of foreign store locations and opening dates with monthly panel data on local barcode-level prices from the 2002-2014 CPI microdata. Since foreign stores are not randomly allocated, the obvious identification concern is that store openings are correlated with pre-existing price trends. There are several possible scenarios. First, it could be the case that foreign retailers target municipalities with higher pre-existing price growth or time their opening in a way that is correlated with positive local retail price shocks. 
Both of these scenarios would lead to an upward-biased estimate of the treatment effect of foreign entry on domestic store prices. Alternatively, foreign stores may target faster growing municipalities whose retail environments are also becoming more competitive so that store prices could be on a pre-existing downward trajectory. Finally, rather than targeting a particular set of municipalities at particular points in time, foreign retailers may have expanded rapidly between 2002 and 2014 with the aim of establishing store presence across the whole of urban Mexico as quickly as possible. In this final scenario, we would not expect substantial bias as, at least over this period, neither the selection of municipalities in our urban estimation sample nor the timing of opening would be strongly correlated with pre-existing price trends.

We use the microdata to explore which of these scenarios is relevant by estimating the following baseline event study specification:

$$
\ln p_{g s b m t}=\sum_{j=-13}^{36} \beta_{j} I\left(\text { MonthsSinceEntry } y_{m t}=j\right)+\delta_{g s b m}+\eta_{t}+\epsilon_{g s b m t},
$$

where $\ln p_{g s b m t}$ is the $\log$ price of a barcode-product $b$ in product group $g$, individual store $s$, in municipality $m$ and month $t . I(\cdot)$ is an indicator function, and MonthsSinceEntry $y_{m}$ counts the months since the first foreign entry for each municipality $m$ at time $t$ (with negative values counting months before entry, positive values counting months after entry and zero being the month the first foreign store enters a municipality). ${ }^{21}$ Since the pro-competitive price effect in equation 7 relates only to price changes at domestic stores, we remove foreign stores from the sample. The $\beta_{j}$ parameters capture the effect of foreign entry on domestic store prices for each of $j$ months before and after the opening event. $\delta_{g s b m}$ is a barcode-by-store fixed effect, and $\eta_{t}$ is a month fixed effect.

By estimating the treatment effect in the 12 months leading up to the opening event, this approach allows us to test for the presence and slope of trends in the run-up to the foreign store opening event in a transparent way and without imposing parametric structure. The absence of pre-existing trends would suggest that the two troubling scenarios outlined above are not an issue, while if there are trends, the event study design allows us to sign and quantify the bias.

To estimate the event study on a fully balanced sample of municipalities both before and after the store opening, we exclude municipalities where the first foreign store opened in the first 12 months of our dataset (July 2002-June 2003), and municipalities where the first foreign store opened in the last 36 months our dataset (April 2011-March 2014) or later. Balancing the panel is important to alleviate selection concerns when exploring the time path of treatment effects. Given the need to balance, there is a clear tradeoff between a longer event study and a smaller, less representative, sample. Our choice of window is guided by the fact that we lose only six percent of our store price observations through this restriction (although, along with other robustness checks, we show results with an extended window below).

\footnotetext{
${ }^{21}$ We take $j=-6$ as the (omitted) reference category and define the indicator variable $I$ (MonthsSinceEntry $\left.m t=36\right)$ to take the value 1 for all $j \geq 36$, and similarly I (MonthsSinceEntry $m=-13$ ) to take the value 1 for all $j \leq-13$. As discussed below, unlike the points in between, these two periods pre and post the event study cannot be estimated using a balanced municipality sample.
} 
Estimation Results Panel A of Figure 2 presents the event study graph. Prices are flat (and not significantly different from zero) in the lead up to the store entry event, start falling as soon as entry occurs, and level off approximately 24 months after entry at a negative and significant 3 percentage points. As evidenced by the treatment effect estimated for post 36 months (labeled " $\geq 36$ " in the figure), this pro-competitive price effect appears to be permanent. When we parametrically test for trend breaks, we find a precisely estimated flat price trend before foreign entry, a significant negative trend break at the time of foreign entry, and a return to a flat price trend about two years after foreign entry. ${ }^{22}$ Note that since the CPI samples products and stores in proportion to their weight in the consumption basket of a representative household, the regressions are implicitly weighted by base-period expenditure weights. ${ }^{23}$ Hence, these point estimates indicate that foreign retail entry significantly lowers the average household retail price index when using a first order Laspeyres approximation. The finding that the coefficients fall gradually in the first two years after opening rather than immediately suggests that local consumers adjust their shopping behavior gradually, as recently found to be the case for US retailers (Einav et al., 2015).

In addition to the baseline event study specification, we present two additional event studies that serve as robustness checks. First, in case our results are driven by more granular trends not captured by the month fixed effects, we replace the 141 month fixed effects with 33,516 store-typeby-product-group-by-month fixed effects, 705 region-by-month fixed effects and 705 municipalitysize-by-month fixed effects (Panel B of Figure 2). ${ }^{24}$ Second, to address any concerns that longer pre-existing trends may not be detected in our 12 pre-months event study, we also extend the event study to include treatment effects for the 24 months before the opening event (Panel $\mathrm{C}$ of Figure 2). The coefficient patterns across the three panels are remarkably similar, and the point estimate increases from a 3 percentage point reduction to 4 percentage points after including the additional controls. Columns 1-3 of Table 2 present the coefficients in table form (in quarterly rather than monthly bins for compactness). ${ }^{25}$

The absence of pre-existing trends in prices relative to locations not receiving their first foreign store, and the subsequent leveling off two years after entry, provides no evidence in support of the hypothesis that foreign retailers targeted municipalities based on pre-existing price trends during

\footnotetext{
${ }^{22}$ We regress log barcode prices on a post-entry dummy, a dummy for 24 months or more post entry and their interactions with MonthsSinceEntrymt in addition to $\delta_{g s b m}$ and $\eta_{t}$. The point estimates on MonthsSinceEntry $m t$ are -.00011 (se=.00036) before entry, -.00116 (se=.00046) for the interaction of MonthsSinceEntrymt with a post-entry dummy, and $-.00010(\mathrm{se}=.00043)$ for the interaction of MonthsSinceEntry mt $_{\text {with }}$ the dummy for 24 months or more post entry.

${ }^{23}$ We confirm the accuracy of theses implicit weights by re-running specification 13 after weighting each price quote observation so that the total weight of each product group matches the consumption weights in the 2002 ENIGH household expenditure surveys. The point estimates reported in online appendix Table A.3 are virtually identical.

${ }^{24}$ Store types refer to either modern store formats or traditional retail outlets. Mexican regions are defined by five contiguous geographical zones according to the Instituto Federal Electoral. Similarly, for the size-by-month fixed effects we assign each municipality in our sample to one of five population quintiles that we define over the population in the year 2000. Note that we do not include barcode-by-month fixed effects since the product descriptions we use to define barcodes are recorded consistently within stores over time, but not necessarily across stores or municipalities.

${ }^{25}$ We also confirm that the results are predominantly driven by single store entry events as claimed at the beginning of this section. Online appendix Table A.4 restricts the estimation sample to municipalities where only one foreign store entered over our sample period. Consistent with the vast majority of foreign entry events involving a single store, the estimates are similar in sign, size and statistical significance.
} 
our sample period or entered in response to changing economic conditions pre-entry. Instead, the results are consistent with a scenario in which foreign retailers rapidly expanded their store networks in order to achieve a store presence across urban Mexico as quickly as possible (and hence variation in opening times is driven by local planning approvals and building delays).

The remaining endogeneity concern is that foreign retailers anticipate breaks in local economic trends. For example, foreign retailers may anticipate local road or other infrastructure investments and target entry to coincide with these investments. We should be clear what would constitute a concern in this context: The local infrastructure investment must be placed at random, in the sense that it is uncorrelated with pre or post trends in prices; it must induce a trend break in prices that lasts only two years since prices return to trend after that; and it must be both anticipated by the foreign retailer, yet the foreign retailer must always precisely preempt its arrival since we see no drop in prices pre-entry. Taken individually, each of these three conditions appear unlikely, particularly the last one given the stochastic nature of delays in both opening a new store and in infrastructure investments. And of course, even if all three conditions are satisfied, it would not appear to be obvious why foreign retailers explicitly target places with anticipated negative price shocks.

Nevertheless, we present two additional robustness checks that serve to address these concerns directly. First, we add direct controls for local government expenditures reported by INEGI at the municipality-year level. As presented in Table 2, the event study coefficients are virtually unchanged after controlling for municipality-year variation in local public expenditure, providing reassurance that our effects are not driven by foreign stores targeting infrastructure investments. Second, we also estimate the baseline event study specification, equation 13, on the non-retail CPI microdata. These data include price time series for consumer expenditures on, for example, the same local hair cut, taxi ride, cleaning service, apartment rent or medical procedure. This serves two purposes. If we do not expect non-retail prices to respond, it serves as a placebo falsification test as omitted variables that change retail price trends would likely also change non-retail prices. Conversely, if we think non-retail prices may respond to foreign retail entry through indirect channels, the size of the response is needed for the quantification exercise. As shown in columns 4 and 5 of Table 2, the point estimates of the event study specifications run on non-retail prices are a series of precisely estimated zeroes. Once again, this placebo result provides reassurance that the timing of foreign entry is exogenous in our specification.

Heterogeneity In our theoretical welfare expression, we allow for heterogeneity in price changes across product groups and store formats (i.e. modern versus traditional). ${ }^{26}$ We can estimate these moments since the confidential version of the CPI microdata provides store formats and retailer names in addition to product groups. We estimate the following specification:

$$
\ln p_{g s b m t}=\sum_{g i} \beta_{g i}\left(\text { ForeignEntry } y_{m t} \times \text { Product }_{g i}\right)+\delta_{g s b m}+\eta_{g i t}+\theta_{r t}+\phi_{z t}+\epsilon_{g s b m t},
$$

\footnotetext{
${ }^{26}$ We also test for heterogeneity across Mexican-US border states (Baja California, Sonora, Chihuahua, Coahuila, Nuevo Leon and Tamaulipas) relative to non-border states, and find no significant differences with the point estimate on the border-state interaction very close to zero (0.002 with standard error of 0.018$)$.
} 
where ForeignEntry $m$ is an indicator that takes the value of 1 if there is a foreign store in municipality $m$ in period $t$ and Product $_{g i}$ is an indicator variable that takes the value of 1 if the retail price quote belongs to product group $g$ and store type $i$ (i.e. modern or traditional). The $\delta_{g s b m}$ are barcode-by-store fixed effects. As before, we also include product-group-by-store-type-bymonth $\left(\eta_{g i t}\right)$, region-by-month $\left(\theta_{r t}\right)$ and municipality-size-by-month $\left(\phi_{z t}\right)$ fixed effects to control for time-varying product-group by store-type specific shocks to prices and shocks that affect regions or municipality types differently. The $\beta_{g i}$ estimates capture the effect of foreign entry on domestic retail prices for product-group $g$ and store-type $i$. As we are not interested in the very short run impacts of foreign retail entry, we exclude price data for the first 24 months post entry to capture medium-run price adjustments (recall that the price coefficients in the event study level off 24 months after entry). ${ }^{27}$ This specification is subject to similar identification concerns discussed above and we rely on the lack of pre-trends in the previously-reported event study.

Table 3 reports the results for food and non food items, for modern versus traditional stores, and for the cross of the two. We find that foreign supermarket entry reduces domestic store prices similarly across both food and non-food products. In contrast, the price reductions appear to be larger for modern domestic store formats than for traditional store formats.

\subsubsection{Post-Entry Price Gaps between Foreign and Domestic Stores}

Empirical Strategy As shown in equation 10, empirical estimates of the post-entry price differences between foreign and domestic stores can be used to estimate a simple and transparent approximation to the direct price index effect (in combination with the pre-post price changes in domestic stores calculated in the previous subsection).

To estimate these post-entry price differences, we compare prices of identical barcodes in the same municipality and month using the consumer panel and the following specification:

$$
\ln p_{g s b m t}=\beta_{g i} \text { DomesticStore }_{s g i}+\delta_{g b m t}+\epsilon_{g s b m t}
$$

where DomesticStore $_{\text {sgi }}$ is a dummy that takes the value of 1 if the retailer is not a foreign-owned store and $\delta_{g b m t}$ is a barcode-by-municipality-by-month fixed effect. As in the previous subsection, to account for potential heterogeneity we also allow the coefficient on DomesticStore sgi $_{\text {in }}$ to vary by food and non food categories $g$, and by modern and traditional stores $i$. Here, and in all our household-level datasets, we weight our regressions using the household survey weights provided to ensure our results are representative.

Estimation Results Table 4 presents the estimation results. As reported in Section 2, foreign stores charge approximately 12 percent lower prices for identical barcode items compared to domestic stores in the same location during the same month. In terms of heterogeneity, the price advantage of foreign stores is most pronounced compared to traditional domestic retailers (a 17 percent price difference), but the difference remains both economically and statistically significant when comparing foreign stores to modern domestic supermarkets (a 4 percent price difference). In

\footnotetext{
${ }^{27}$ Formally, we cannot reject that the effect 24 months after entry is different to the effect more than 24 months after entry using the specifications in columns 1-3 of Table 2 (p-values of $0.74,0.31$ and 0.56 respectively).
} 
terms of heterogeneity across product groups, the price differences appear to be most pronounced for food relative to non-food product groups.

\subsection{Effect on Consumption Quantities}

\subsubsection{Post-Entry Market Shares of Foreign Retailers}

Empirical Strategy To calculate the direct price index effect in expression 7, we require estimates of the effect of foreign supermarket entry on the retail expenditure shares of foreign stores (broken down by both product group and household income group). To obtain these estimates we again turn to the consumer panel microdata and estimate the following specification:

$$
\sum_{s \in S_{g m t}^{f}} \phi_{g s h m t}=\beta_{g h}+\epsilon_{g h m t}
$$

where $\sum_{s \in S_{g m t}^{f}} \phi_{g s h m t}$ are retail expenditure shares spent at foreign stores by individual household $h$ in product group g. We estimate the average post-entry expenditure shares at foreign stores, $\beta_{g h}$, separately for each of 12 product groups and 7 household income groups in the consumer panel data described in Section 4. As above, we restrict our sample to focus only on expenditure shares of foreign stores in locations where a foreign retailer had been open for 24 monthsor more (recall the price effects leveled off at 24 months suggesting consumer shopping habits are stable by that time). Thus, this specification estimates medium-run market shares of foreign stores.

Estimation Results Figure 3 presents the results. On average, foreign stores capture more than 30 percent of total household retail expenditure after entering. Via revealed preference these results provide prima facie evidence of substantial consumer gains from retail FDI in a developing country context.

The consumer panel includes locations that received their first foreign stores prior to the start of our estimation sample in 2002. These early receivers may differ from the locations where foreign entrants arrived during our 2002-2014 sample period, or may have experienced subsequent shocks that altered their demand for foreign retailers. As a robustness exercise, we find similar results when we restrict the estimation of equation 16 to municipalities where foreign retail first arrived between 2 and 3 years previously where such concerns will be less pronounced (see online appendix Figure A.1). ${ }^{28}$

The post-entry expenditure shares on foreign stores differ significantly across the income distribution. The upper panel of Figure 3 shows that the wealthiest households spend more than 50 percent of their retail expenditure at foreign stores while the poorest just over 10 percent. These substantial differences in the extent to which local households substitute towards shopping at foreign stores suggest significant differences in how rich and poor households evaluate the amenities and product mix offered by foreign retailers (as captured by the taste shifters and store-income-group-specific price indices in our CES preference structure). Note, these differences across income groups come primarily from variation across income groups within locations rather

\footnotetext{
${ }^{28}$ Note that since the consumer panel starts in 2011 and covers large urban municipalities that almost all had foreign stores by that time, we cannot carry out an event study looking at pre and post-entry market shares of foreign stores.
} 
than simply variation across poor and rich locations: we find similar differences when we include municipality-by-quarter fixed effects in Figure A.2 of the online appendix.

The lower panel of Figure 3 reports foreign-store expenditure shares across 12 product groups. We find substantial differences across product groups; the foreign retail share in personal care products is above 40 percent but below 15 percent for beverages. For the quantification itself, we draw on the cross of the income and product group dimensions and allow foreign retail expenditure shares to be income-group-by-product-group specific.

\subsubsection{Effect on Domestic Store Exit}

Empirical Strategy To estimate the pro-competitive exit effect in expression 7, we require data on the market shares of exiting stores. Since the consumer panel only spans a short time window and the CPI price data do not contain quantities, we rely on store counts from the microdata of the Mexican retail censuses collected in 2003 and 2008 (and implicitly assume that closing stores had average market shares). ${ }^{29}$ Hence, we estimate the following specification (separately for traditional and modern establishments):

$$
d \ln N_{-} \text {Establishments }{ }_{m}^{03-08}=\beta d \text { ForeignEntry }{ }_{m}^{03-08}+\gamma X_{m}+\epsilon_{m}
$$

where the dependent variable is the change in the log number of retail units across the two census rounds and the key independent variable is dForeignEntry ${ }_{m}^{03-08}$, the change in the foreign entry dummy between the two census rounds (i.e. whether the first foreign store opened between censuses). We also include a set of municipality controls $X_{m}$, the most important of which is a dummy for whether the municipality already had a foreign store at the time of the first census in 2003 (these municipalities are much larger, more likely to be located in the center of the country and presumably experienced different trends compared to municipalities that foreign stores entered in the major wave of expansions we study). Unlike in the household datasets, no survey weights are provided. We report the basic unweighted results, as well as results weighting by municipality employment counts from the 2003 Economic Census for consistency with other estimates in the paper.

For $\beta$ to yield an unbiased estimate of the effect of foreign entry on store counts, we require that foreign entry decisions between 2004 and 2008 are not correlated with other variables that drive changes in the number of local retail establishments. While the event studies in other subsections provide some support for this assumption, the lack of available high frequency data on local store counts precludes a similar strategy here. To partially address such concerns, we present a number of robustness checks. As in the price regressions, we report estimation results that include additional sets of municipality-level controls: region fixed effects, municipality size fixed effects, and contemporaneous changes in both log public expenditures and log GDP per capita.

Estimation Results Table 5 presents the estimation results. Foreign entry has a negative and statistically significant effect on the number of traditional retailers. The size of the preferred point estimate in column 12 (weighted with controls) implies a 3.9 percent reduction. Reassuringly, the

\footnotetext{
${ }^{29}$ This assumption is likely conservative. If store closures were concentrated in stores with small market shares, then the welfare gains we report in our quantification would be even larger.
} 
point estimate is similar across the various specifications. The coefficient estimate on store exit among modern domestic store formats is also negative and also equal to a 3.9 percent reduction, but is not statistically significant at conventional levels. Hence, we find negative but moderate effects on domestic store exit over our five year time horizon.

\subsection{Effect on Nominal Labor Incomes, Business Incomes and Employment}

Empirical Strategy To calculate the income effect in expression 12, we require estimates of the causal impact of foreign retail entry on nominal incomes and employment in the location where retail entry occurred. To do so, we start by running an event study specification similar to our price event study above, but here using quarterly income and employment data from the employment and occupation survey microdata:

$$
\ln \text { Income }_{k m t}=\sum_{j=-5}^{12} \beta_{j} I(\text { QuartersSinceEntry } m t=j)+\gamma X_{k m t}+\delta_{m}+\eta_{t}+\epsilon_{k m t},
$$

where $\ln$ Income $_{k m t}$ is log monthly nominal income for individual $k$ residing in municipality $m$ in quarter $t$. $X_{k m t}$ are person controls including a gender dummy, dummies for completed degrees (below primary, primary, secondary and higher) and third order polynomials for age and years of schooling. ${ }^{30}$ We also run an identical specification for employment that replaces $\ln I n c o m e_{k m t}$ with $E_{m p l o y_{k m t}}$, an indicator variable that takes the value of one if the person is employed. Hence, the $\beta_{j}$ coefficients uncover pre and post foreign entry movements in income and employment.

As discussed above, the event study design allows us to explore pre-existing trends in the run up to the store opening event. Again, there are several potential scenarios. Foreign retailers could target municipalities with either higher or lower pre-existing income growth rates. Alternatively, consistent with our price event study, foreign retailers may have expanded rapidly to establishing store presence across urban Mexico in a way that was uncorrelated with local shocks or pre-existing trends in incomes or employment (at least for our urban estimation sample).

As in the price event study, we balance the estimation sample between one year before and three years after the store entry event. ${ }^{31}$ In addition to these baseline specifications, we also estimate a number of additional robustness checks. As before, we replace the quarter fixed effects with region-by-quarter as well as municipality-size-by-quarter fixed effects, and estimate specifications with both a one year pre period as well as an extended event study with a two year pre period.

To estimate the effect of foreign retail entry on business incomes among local store owners, we return to the retail census microdata, and estimate specification 17 above after replacing the dependent variable $d \ln N_{-}$Establishments ${ }_{m}^{03-08}$ by $d \ln \left(\overline{\text { Profits }_{m}}\right)^{03-08}$, the change in log mean municipality profits for traditional retail establishments. ${ }^{32}$ For the quantification exercise, we re-

\footnotetext{
${ }^{30}$ Note we do not include worker fixed effects as the dataset is a rotating panel where individuals are followed for a maximum of 5 quarters. Therefore, worker fixed effects sweep out any foreign-entry-induced changes in income across cohorts entering the panel at different times. For completeness, online appendix Table A.5 also reports results with worker fixed effects.

${ }^{31}$ This restriction excludes ten percent percent of our observations. The majority (6 percent) of these excluded observations are in urban municipalities that had not yet received a foreign store at the end of our sample in March 2014.

${ }^{32}$ We do not estimate the effect on modern retail profits for two reasons. The first reason is conceptual. Given
} 
quire an estimate for the effect on total retail profits accruing to local households (inclusive of the lost profits of exiting traditional stores). This total effect is given by the sum of the profit effect and the store exit effect already calculated in Section 5.2.2.

Estimation Results Figures 4 and 5 and Table 6 present the estimation results for the income and employment event study described above. In contrast to the price event study, we find no evidence of either jumps in levels or breaks in trends around the period of foreign retail entry (or evidence of pre-existing trends). There appears to be no general equilibrium income or employment effects in the municipality, perhaps not surprisingly given that one store hires only a small number of employees. For completeness, Table A.5 in the online appendix also provides the regression table. Table A.5 also shows that we find no evidence of changes in population, at least over the time horizon we study: we aggregate the worker weights up to the municipality-level and regress $\log$ municipality population counts on quarters-since-entry dummies, municipality fixed effects and quarter fixed effects, and find statistically insignificant point estimates that are close to zero.

Table 7 presents the estimation results for domestic store profits using the retail census microdata. Foreign entry has a negative effect on retail profits for traditional store owners. The significance of the point estimate on profits depends on whether the specification is population weighted or not, but ranges between -4.4 and -5.1 percent. Reassuringly, this point estimate varies little when we include regional fixed effects, initial municipality size fixed effects, or control for contemporaneous changes in local government expenditures or GDP per capita.

Heterogeneity To quantify to what extent households may be affected differently depending on their primary source of income pre foreign entry, we require not just the general equilibrium income and employment effects, but also estimates broken down by sector. We now turn to exploring this heterogeneity. Since individuals may change sector or become unemployed over time, and the employment and occupation surveys only follow individuals over 5 consecutive quarters, we cannot directly assess longer-run outcomes for workers with different pre-foreign-entry occupations. Instead, we calculate both the average income and employment changes across various sectors and apply the decomposition outlined in equation 12 of the theoretical framework.

To obtain average changes in nominal incomes across sectors, we regress individual log income on a foreign entry dummy that takes the value 1 when there is a foreign store in the municipality interacted with a sector dummy that takes the value 1 if a worker is employed in that sector:

$$
\ln \left(\text { Income }_{\text {kimt }}=\sum_{i} \beta_{i}\left(\text { ForeignEntry }_{m t} \times \text { Sector }_{i}\right)+\gamma X_{\text {kimt }}+\delta_{m t}+\eta_{\text {im }}+\theta_{i t}+\epsilon_{\text {kimt }},\right.
$$

where subscripts $k, i, m$ and $t$ index individuals, sectors, municipalities and quarters respectively. $\delta_{m t}$ is a municipality-by-quarter fixed effect, $\eta_{i m}$ is a sector-by-municipality fixed effect, and $\theta_{i t}$ is a

that we are interested in the welfare effect of foreign entry on local households, the profits of retail chains that are repatriated to their headquarters in other locations should not enter the welfare expression in equation 12 other than through the shareholdings of local residents which are likely to be small. The second reason is data constraints. While in the exit regressions we were able to observe the total number of modern stores and subtract off the number of foreign owned stores in the ANTAD data, we cannot do the same for profits since ANTAD do not report them and the census data do not allow us to distinguish between domestic and foreign stores in the modern retail sector. 
sector-by-quarter fixed effect. Our sectoral categories consist of two retail categories, retail workers in either modern or traditional store formats; as well as two non-retail categories, individuals whose main income source is either agriculture or manufacturing. The omitted category contains individuals whose main income source is in non-retail services (e.g. education, health, restaurant or domestic services). ${ }^{33}$ We assume this large omitted category experiences no income changes with foreign entry based on the flat event study plots for average incomes above.

The coefficients $\beta_{i}$ capture the differential effect of foreign store entry on the incomes of various sectors (conditional on flexible trends at the municipality-quarter level, initial earnings differences across sectors within the municipality and national differences across sectors in that quarter). Finally, we remove observations covering the 24 months after the first foreign store entry to avoid capturing the short-run adjustment period we noted in the price regressions above.

Table 6 presents these results. In contrast to the average income regressions, we find a negative and significant effect on the incomes of traditional retail workers. This point estimate is robust to including income-group-by-quarter fixed effects as well as state-by-income-group specific time trends, implying that this effect is not driven by pre-existing trends that are specific to particular income groups. The point estimate corresponds to a reduction in the monthly incomes of traditional sector retail workers of 5.9 percent as a result of foreign retail entry. We find a smaller and insignificant 2.8 percent decline in the labor incomes of modern retail workers. In contrast, incomes in agriculture and manufacturing -individuals who may be supplying foreign retailers—rise but by small and insignificant amounts.

Finally, we turn to employment changes across sectors. We regress the log number of employed workers in municipality $m$, sector $i$ and quarter $t$ on all the variables on the right hand side of equation 19 except for the vector $X_{\text {kimt }}$ of individual-level controls. The final three columns of Table 6 report these coefficients. We find a significant and substantial reduction in traditional retail employment of 11.3 percentage points. This is partially compensated by an (insignificant) 3.9 percent increase in employment in the modern sector, potentially coming from employment at the foreign store itself. The employment changes in agriculture and manufacturing are small and insignificant (once again relative to the omitted category, non-retail services).

\section{Quantifying the Welfare Effect of Foreign Retail}

In order to quantify the effects of foreign retail entry on local household welfare using equations 7 and 12, we require two more inputs beyond the causal effects on prices, quantities and incomes we estimate above. First, we need an estimate of the elasticity of substitution across local retail outlets (the $\eta_{g h}$ parameters in equation 7). Second, we require estimates of household budget shares across product groups (the $\alpha_{g h}$ parameters in equation 7), pre-entry store-type expenditure shares (to calculate the $\omega_{\text {gsh }}$ weights in equation 7 ), and pre-entry income shares across sectors

\footnotetext{
${ }^{33}$ Although these data also report business incomes in retail, we exclude the small fraction of retail business owners. This is because we already have an estimate for the effect on retail profits using the retail census data where the profit data are more reliable for self employed business owners and the number of observations is far larger. (The employment and occupation surveys contain a median of only 9 store owners in each municipality-quarter cell.)
} 
and occupations (the $\theta_{i}^{0}$ terms in equation 12). Armed with all three types of moments, we then proceed to the quantification.

\subsection{Estimation of the CES Elasticity Parameter}

To estimate the elasticity of substitution across local retail outlets we use the consumer panel microdata. The strength of these data is that we observe how much each household purchases of a particular barcode-equivalent product, at what price and at which specific store. Thus, we can observe how store-level market shares vary with store-level prices across various locations. We exploit this cross-location variation (rather than the time series) for two reasons: this variation is more likely to provide estimates of the long-run elasticity relevant for estimating the gains from new foreign retail store openings, and because the consumer panel has a relatively short duration (10 quarters between 2011-14).

To derive our estimating equation, note that in the CES case the log expenditure share of store brand $s$ (e.g. Walmart) within product group $g$ (e.g. beverages) can be written as

$$
\ln \phi_{g s h m t}=\left(1-\eta_{g h}\right) \ln r_{g s h m t}-\left(1-\eta_{g h}\right) \ln c_{g h m t}+\eta_{g h} \ln \beta_{g s h m t}
$$

where $c_{g h m t}=\left(\sum_{s \in S_{g m t}} \beta_{g s h m t} \eta_{g h} r_{g s h m t}{ }^{1-\eta_{g h}}\right)^{\frac{1}{1-\eta_{g h}}}$ is the product-group specific CES price index, $r_{g s h m t}$ is the store-product-group specific price index and $\beta_{g s h m t}$ is a store-product-group specific taste shifter for household $h$ in municipality $m$ quarter $t$. Thus, if we regress log expenditure shares on local store-level price indices, use fixed effects to sweep out the CES price index, and deal with endogeneity due to the taste shifter, we can recover the elasticity of substitution across stores, $\eta_{g h}$.

To implement this procedure, we must place additional structure on the multi-tier preference structure we introduced in equation 3. First, since we will not be able to match individual households in the consumer panel to households in the income and expenditure surveys, we aggregate households into broad income groups (the 7 income groups in the consumer panel). Second, we must impose some discipline on the store-specific taste shifters for them not to soak up all the variation in expenditure shares. Our basic specification allows tastes to differ both across time for each retail-chain-product-group pair (for example due to a national advertising campaigns for a retail chain) and across municipalities for each retail chain (for example because a retail chain is located on the outskirts of some municipalities and the center of others). We also report additional specifications that allow tastes to vary at the retail-chain-municipality-quarter level or retail-chain-municipality-product-group level.

Finally, in order to calculate the store-level price index we require a functional form for the lowest tier of consumer preferences-household preferences across products within a store-productgroup - that we left unspecified up to now. In principle, we could use any demand system. For simplicity and transparency, we choose the widely-used Stone price index, which is just a budgetshare-weighted sum of $\log$ prices; $\ln r_{g s h m t}=\sum_{b \in B_{g s h m t}} \phi_{g s b h m t} \ln p_{g s b h m t}$. As products differ across stores, and some stores may sell higher-quality varieties, we use barcode fixed effects to ensure that we are only comparing identical products to extract these price index differences. To be precise, we recover $\ln r_{g s h m t}$ from the store fixed effects in a regression of budget-share-weighted log 
prices at the barcode level on both store and barcode fixed effects, where this regression is run separately for every product-group income-group municipality time cell. ${ }^{34}$ This procedure is similar to extracting firm fixed effects from matched employer-employee data, and we follow that literature by estimating price indices off the largest 'mobility group' of connected stores and barcodes.

Given this additional structure, we can run the following regression:

$$
\ln \phi_{g s h m t}=b_{g h} \ln r_{g s h m t}+\delta_{g h m t}+\gamma_{c g t}+\gamma_{c m}+u_{g s h m t}
$$

where $u_{\text {gshmt }}$ is the error term, $\delta_{\text {ghmt }}$ are product-group-by-income-group-by-municipality-by-time fixed effects that sweep out the CES price index $\ln c_{g h m t}$, and the $\gamma$ terms are retail chain $c$ fixed effects to capture the unobserved taste shifters. The object of interest is $1-b_{g h}$, an estimate of the elasticity $\eta_{g h}$ that governs the degree of substitutability between local retail outlets as a function of store price differences. To fix ideas via a simple example, we are essentially comparing one location where Soriana has relatively high prices for beverages compared to Walmart, with another location where the two stores have similar prices, and inferring the elasticity of substitution from the difference in relative market shares across the two locations. As in previous sections, we allow this elasticity parameter to differ across food and non-food retail product groups as well as across two broad income groups, "rich" and "poor" (defined as above and below median). ${ }^{35}$

A shortcoming of the consumer panel data is that unique store-brand identifiers are only recorded for the modern retail sector. For this reason, we are restricted to calculating elasticities of substitution from the market shares of retailers in the modern sector. Given that similar store formats are presumably closer substitutes, this approach likely generates higher $\eta_{g h}$ estimates (and hence lower direct price index effects). We will explore the sensitivity of our estimates to allowing the elasticity of substitution to differ both across and within modern and traditional store types.

As in any demand estimation, there are simultaneity concerns if demand shocks in the error term raise both store-level market shares and store-level price indices. To deal with this concern we follow Hausman (1996) and instrument the store-product-group price index with price indices in stores of the same retailer in other municipalities. In particular, we exploit the fact that there is both a local and national/regional component to prices at supermarket chains-with the local component potentially related to idiosyncratic local demand shocks and the national/regional component related to common suppliers and distribution networks as well as national/regional pricing rules (see, for example, Beraja et al., 2014; DellaVigna and Gentzkow, 2015). ${ }^{36}$ This supply-

\footnotetext{
${ }^{34}$ Given the nature of the microdata, we first collapse the price data to average prices at the barcode-storemunicipality-quarter level. Alternatively, we collapse them to median prices, and we will report both specifications. For comparability across locations, the resulting store fixed effects are then demeaned within each product-group income-group municipality time cell.

${ }^{35}$ Despite the richness of these data, the variation thins if we allowed for heterogeneity along more granular dimensions of $h$ and $g$ (we observe on average only 40 households in a given quarter-municipality cell).

${ }^{36}$ In support of this claim in the Mexican context, we find that in the consumer panel data the variance of log prices within a retailer-barcode-quarter is 0.458 nation-wide, 0.395 within a given region, and only marginally lower at 0.347 within a given state. When including cross-retailer variation (i.e. within barcode-quarter), the variances of log prices are all higher (0.554 nation-wide, 0.522 region-wide, and 0.476 state-wide). More directly, prices are correlated across stores within a chain: a regression of log prices on retailer-barcode-municipality fixed effects and the leave-out mean of prices for that barcode at that store in other locations nation-wide results in a coefficient of 0.387 (and attenuated
} 
side price variation allows us to identify the elasticity of substitution. Thus, we instrument using product-group specific price indices constructed either from national leave-out means for that retailer or from regional leave-out means (using five Mexican administrative regions). As recently shown by Beraja et al. (2014), these two instruments identify potentially different local average treatment effects. The national leave-out means estimate the elasticity of substitution based on retail chains that have common national supply shocks or pricing rules, whereas the region-level leave-out means extend the complier group of the IV to regional supply shocks and pricing rules.

Table 8 presents the estimation results for both the average elasticity of substitution as well as allowing the elasticity to vary by income and product group. For both IV strategies, and all three different taste shifter fixed effect specifications, the elasticity estimates are consistently negative, significant and have substantial first-stage F-statistics. The average elasticities range between 2.28 and 4.36, well within the range of existing estimates that use scanner consumption microdata for the US (e.g. Hausman and Leibtag, 2007; Handbury, in press). As is evident from the cost of living expression, equation 7 , larger elasticity estimates result in smaller direct price index effects. Therefore, we base our welfare quantification on the specification that yields the most conservative (highest) average estimate of the elasticity of substitution across local retail outlets (those reported in columns 9 and 23 of Table 8). In addition to choosing the most conservative $\eta_{g h}$ estimates, we also rerun our quantification both across a range of alternative average elasticities of substitution for which our preferred $\eta_{g h}$ estimates form the mid point, and using the first order approximation approach outlined in Section 3 that does not require estimates of this elasticity. Finally, online appendix $C$ performs a variety of additional robustness checks (including controls for variety, using an unweighted price index, using only cross-sectional variation, restricting attention to a subset of common products, and restricting attention to stores with strong national pricing strategies), with the resulting elasticities all falling within this range.

\subsection{Combining the Estimated Moments for the Quantification}

In order to calculate the welfare expressions derived in Section 3, we still require one final set of moments: estimates of pre-entry income and expenditure shares across the distribution of households. For these moments we draw on our sixth and final dataset, the Mexican household income and expenditure surveys. The household-level shares from these data, combined with the previous moments estimated at the income-group-by-product-group level, will allow us to estimate the welfare gains from foreign retail entry separately for each household in the survey. As we require pre-entry income and expenditure shares, we restrict attention to the 12,293 households surveyed over the period 2006-2012, who reside in the 240 urban municipalities without foreign stores at the time of the survey. ${ }^{37}$

On the income side, the surveys record the share of income from each sector and occupation

coefficients of 0.228 region-wide and 0.160 state-wide).

${ }^{37}$ A potential concern is that the locations in our quantification sample may differ from the locations that did not have a foreign store at the start of 2002, the baseline sample we estimate various moments from. Therefore, online appendix Table A.6 presents quantification results that re-weight the household sample so that the distribution of either municipality populations or supermarkets per capita matches the distribution in the baseline sample. The magnitude of the welfare effects are almost identical. 
(business owner or employee) which provides the pre-entry income shares (the $\theta_{h}^{0}$ parameters in equation 12). Alongside the causal income, employment and profit changes presented in Section 5 , we have all the moments necessary to quantify the three nominal income effects in equation 12.

To quantify the retail profit effect, we randomly assign a profit loss of 100 percent to a random 3.9 percent of traditional store owners in the income and expenditure surveys (based on the estimate of traditional store exit from Section 5.2.2). We assign the remaining 96.1 percent of traditional store owners a profit loss of 4.4 percent (based on the traditional store profit decline estimated in Section 5.3). To quantify the labor income effects, we use the estimates of the sectoral income and employment effects two years post foreign entry in Columns 3 and 6 of Table 6 to compute the expressions in equation 12 and footnote 17 (assigning an income loss of 100 percent to a randomly chosen fraction of households equal to the estimated employment decline, and assigning the estimated wage decline to the remaining households). ${ }^{38}$

We now turn to the cost of living expression under the exact (CES) approach, expression 7. For each household, the income and expenditure surveys record household expenditures in each product group (the $\alpha_{g h}$ parameters). In Section 5.2 we obtained estimates of the share of retail expenditure at foreign stores post entry $\left(1-\sum_{s \in S_{g}^{d c}} \phi_{g s h}^{1}\right)$ by income group and product group (shown visually in Figure 3), and at exiting stores pre entry $\left(1-\sum_{s \in S_{g}^{d c}} \phi_{g s h}^{0}\right)$ (columns 12 and 16 of Table 5). Coupled with the elasticity of substitution across stores $\eta_{g h}$ estimated in Section 6.1 above, we are in a position to calculate the key components of the direct price-index effect and the procompetitive exit effect.

The remaining cost of living term is the pro-competitive price effect. This is a function of causal changes in store-price indices, $\frac{r_{g s h}^{1}}{r_{g s h}^{0}}$, and ideal log-change weights, $\omega_{g s h}$. Recall that in Section 5.1, we obtained estimates of causal price changes at domestic retail stores two years post foreign entry for food and non-food groups in both traditional and modern stores (column 4 of Table 3). Accordingly, we assume that all product-level price changes within these product-group-by-store-types are the same, $\frac{p_{g s b}^{1}}{p_{g s b}^{0}} \equiv p_{g s}$, where the store $s$ now indexes two types, modern domestic $\mu$ and traditional domestic $\tau$; and product group $g$ now indexes two groups, food retail and non-food retail. We later relax this assumption and allow for different price changes across barcoded and nonbarcoded products. Given that we found a precise zero on non-retail consumer prices (column 5 of Table 2), we set the price changes equal to zero across all non-retail product groups.

The ideal log-change weights, $\omega_{g s h}$, that weight these domestic store price changes in the CES price index can also be calculated. These are simple functions of pre- and post-entry expenditure shares for each store type within each product group. Fortunately, the design of the income

\footnotetext{
${ }^{38}$ More precisely, households with members employed in a given sector (traditional retail, modern retail, agriculture or manufacturing) receive their initial income share in that sector multiplied by the average income effect estimated in Column 3 of Table 6. For sectors experiencing employment reductions of $x$ percent in Column 6, we apply a 100 percent reduction in income to a random $x$ percent of households working in that sector. For sectors experiencing gains of $x$ percent, we increase income for a random $\frac{x \rho}{1-\rho}$ percent of households not working in that sector by the average local earnings in that sector divided by total household income (where $\rho$ is the proportion of local employment in that sector). We set the employment change to 0 in agriculture given the point estimate of 0.00811 and the large standard errors due to the small number of agricultural employees in our urban sample.
} 
and expenditure surveys are extremely helpful in this regard. As described in Section 4, the four survey rounds we use break down household expenditures in each product group into expenditures at different types of store. This break down allows us to directly observe the pre-entry store-type expenditure shares, $\tilde{\phi}_{g s h}^{0}$, for each household and product group. We then use the CES structure to calculate post-entry shares, $\tilde{\phi}_{\text {gih }}^{1}$, by combining these pre-entry shares with the causal price changes by store type discussed above and our elasticity of substitution estimates:

$$
\tilde{\phi}_{g i h}^{1}=\tilde{\phi}_{g i h}^{0}\left(\frac{\left(p_{g i}\right)^{1-\eta_{g h}}}{\left(p_{g \mu}\right)^{1-\eta_{g h}} \tilde{\phi}_{g \mu h}^{0}+\left(p_{g \tau}\right)^{1-\eta_{g h}} \tilde{\phi}_{g \tau h}^{0}}\right)
$$

where $i$ takes the value $\mu$ or $\tau$.

Finally, the cost of living expression under the first order approach is relatively straightforward to quantify. We require two sets of price changes: the pre-post price changes in domestic stores for the pro-competitive effect (expression 9); and the sum of these pre-post price changes and the post-entry price gaps between domestic and foreign stores for the direct price index effect (expression 10). As above, we assume that these price changes and price gaps were common across all products within each product-group-by-store-type pair and draw on our estimates from Table 3 (price changes) and Table 4 (price gaps). For the post-entry expenditure weights, $\phi_{b s h}^{1}$, that weight these price changes and price gaps in the Paasche indices, we start with the product-group shares for each household from the income and expenditure surveys. These are then multiplied by the domestic (for the pro-competitive price effect) or foreign (for the direct price index effect) market shares within each product group, as well as the store-type shares within each product group, both obtained from households in the same income bin in the post-entry-period consumer panel data.

Before performing the quantification, we need to confront the fact that the estimates of the causal effects of foreign retail entry on consumer prices, quantities and incomes that enter the quantification are subject to sampling error. To obtain standard errors and confidence intervals that take this error into account, we bootstrap the entire quantification exercise 1000 times. In each bootstrap, we both draw a random sample from our 12,293 households (sampling with replacement); and redraw each price, quantity and income parameter from a normal distribution with a mean equal to the point estimate and a standard deviation equal to the standard error of the estimate. ${ }^{39}$ Finally, as mentioned above, for robustness we recompute the quantification for a range of elasticity estimates (recall we chose the most conservative specification in our baseline quantification), and for a range of assumptions on price changes for non-barcoded retail items (recall we assumed these changes were equal to those of barcoded items in our baseline quantification).

\subsection{Quantification Results}

\subsubsection{The Average Welfare Gains from Foreign Retail Entry}

We first present the results of the quantification under the exact (CES) approach. As described above, the income and expenditure surveys allow us to calculate the welfare gains for each household in our sample based on the occupations and sectors they work in, the products they spend

\footnotetext{
${ }^{39}$ This is a parametric bootstrap (e.g. Horowitz, 2001) that implicitly assumes errors are uncorrelated across datasets.
} 
their income on, and the types of stores they shop at. Column 1 of Table 9 presents the mean of the total welfare gain across all these urban households (using the household survey weights) as well as the max, the min and the proportion negative. The various sub components of the total welfare effect are reported in columns 2-7. On average, we find that foreign store entry leads to large and significant welfare gains for households in the municipality where the foreign-owned retailer enters. These gains are in the order of 6 percent of initial household income.

Turning to the sub components, our positive total welfare effect is driven by a significant reduction in the cost of living - 6.4 percent welfare gain — that far outweighs the effects on the nominal income side. While the adverse effects on the incomes of traditional retail workers and local store owners are economically significant (recall their income losses were around 6 percent and employment losses were even larger), these effects are muted for the municipality as a whole since only a fraction of households derive substantial shares of their total income from these sources. In contrast, retail constitutes a large part of household total consumption for every household, generating substantial cost of living reductions.

Honing in further, about one quarter of the cost of living effect, or 1.6 percent, comes from the pro-competitive price effect, the price reductions at domestic stores induced by the entry of foreign retailers. (An effect size approximately equal to the following back of the envelope calculation: the share of retail in expenditure ( 0.5 on average) multiplied by the average domestic market share pre and post foreign entry $((1+0.7) / 2=0.85$ on average) multiplied by the price reduction in domestic stores (0.04 on average)). The pro-competitive exit effect, the welfare losses due to shop closures, is small at -0.7 percent since the number of store closures was limited (at least over our 5 year window). The remainder of the cost of living effect, 5.5 percent, is due to the direct price index effect of foreign entry, the consumer gains from being able to shop at the foreign store itself. (A finding that was foreshadowed in the raw data by the 12 percent lower prices charged by foreign stores and their 30 percent post-entry market shares.)

On the income side, there is an average loss of 0.40 percent from declines in retail labor income, a loss of 0.27 percent from declines in retail profits, and a gain of 0.29 percent from increases in other incomes (with the intensive margin alone-i.e. wage and profit changes not employment changes or store exit-accounting for losses of $0.19,0.14$ and gains of 0.49 percent, respectively).

We report the results of the first order approach in columns 8-14 of Table 9. The total effect is smaller under this approach, with the average gains equal to 2.8 percent of initial household income. This is driven by a smaller direct price index effect of 2.0 percent. (Approximately: the share of retail in expenditure ( 0.5 on average) multiplied by the foreign post-entry market share ( 0.3 on average) multiplied by the price reduction in domestic stores plus the post-entry price gap between foreign and domestic stores (0.16 on average).)

Recall that the first order approach uses a Paasche approximation of the direct price index effect-post-entry expenditure shares multiplied by observable price changes-that is analogous to estimating the gains if foreign stores always existed but simply charged domestic prices in the pre-entry periods. Hence, it does not capture three potentially important welfare gains due to foreign store entry: new product variety on sale at foreign stores, different shopping amenities 
available at foreign stores, and the additional store variety that comes from having an extra shopping choice. In contrast, we prefer the exact (CES) approach above precisely because these three channels are captured in the CES direct price index effect alongside lower prices. Hence, in an approximate sense, the fact that the direct price index effect is 40 percent as large under the first order approach (2.0 percent as opposed to 5.5 percent) suggests that these variety and amenity gains account for a substantial proportion of the cost of living effect. ${ }^{40}$ Given the large differences between foreign and domestic stores that we highlighted in Section 2, the sizable gains generated by these variety and amenity channels seem plausible (a discussion we will return to when assessing the distribution of the welfare gains).

Finally, we explore the sensitivity of our average total effect to alternative values of two parameters that are key drivers of the quantification results: the elasticity of substitution across local stores and the price changes for non-barcoded products. Our baseline quantification above used the most conservative estimate of the elasticity of substitution, a specification that yielded point estimates around 4 for the product-and-income-group specific elasticities (column 23 of Table 8). We take these $\eta_{g h}$ estimates as the mid points and re-estimate the full quantification exercise using 8 alternative sets of elasticities, either subtracting or adding $0.5,1,1.5$, and 2 to the midpoints. On the price side, our baseline quantification imposed the assumption that price changes were the same across barcoded and non-barcoded products within a product group and store type and then used the barcoded estimates from Section 5.1 where we could control for product characteristics. ${ }^{41}$ Again, we take this assumption as our mid point and re-estimate the quantification assuming there were no price changes for non-barcoded items, the price changes were 50 percent as large, 150 percent as large, or 200 percent as large. Table 10 reports the total welfare effect for the 9 times 5 different combinations of elasticities and non-barcode price changes. Reassuringly, despite the wide parameter ranges, the total effects remain reasonable, varying between 3.3 and 14.7 percent.

Our multi-tiered preference structure imposes that the elasticity of substitution is the same across traditional and modern stores. We may expect the elasticity of substitution within modern store types to differ from that across modern and traditional stores. To allow for such heterogeneity while maintaining the CES middle tier, we rerun the quantification but placing traditional and modern stores in different CES nests within a product group-implicitly imposing a low elasticity of 1 across traditional and modern stores due to the Cobb Douglas upper tier. As shown in online appendix Table A.7, the average total effect falls in this scenario since we shut down the direct gains from foreign stores capturing market share from traditional stores. However, the magnitudes remain similar with average gains of 5.2 percent if we use the same elasticity of substitution within the traditional nests that we estimated in Section 6.1 using data on consumer substitution

\footnotetext{
${ }^{40}$ As noted in footnote 16 , the direct price index is biased upwards using a Paasche approximation. However, this bias is small. A Sato-Vartia price index using our CES framework and the $\eta_{g h}$ estimates from Section 6.1 to estimate the initial market shares if foreign stores had charged domestic prices yields a direct price index effect of 1.9 percent rather than 2.0 percent. Conversely, the pro-competitive price effect is biased downwards, rising from 1.09 percent under the Paasche first order approach to 1.15 percent when using the Sato-Vartia approach.

${ }^{41}$ This baseline assumption is consistent with Hausman and Leibtag (2007) who find similar price changes in branded and unbranded products upon the entry of big box stores in the US.
} 
across modern stores (rising to 5.4 percent if we assume the elasticity of substitution is instead 6 within traditional stores so that traditional-store exit is less deleterious, and falling to 4.4 percent if we assume it is 2 instead).

\subsubsection{The Distribution of the Gains from Foreign Retail Entry}

In the previous section we reported average household effects. Since we have a separate estimate for each sample household in the income and expenditure surveys, it is straightforward to analyze the distribution of these gains. The upper panel of Figure 6 plots the total welfare effect for each household against the initial position of the household in the income distribution using a non-parametric local polynomial regression. The lower panel decomposes these gains. For both, we focus on our preferred exact (CES) approach (online appendix Figure A.3 plots the distribution using the first order approach). While all income groups benefit substantially from foreign retail entry, richer households gain substantially more than poorer households (about 7.5 percent compared to 5 percent).

Where does this regressiveness come from? We present several counterfactual exercises that allow us to analyze the interplay of forces underlying this result. We focus on the role of several key differences in shopping and income patterns across the income distribution: the share of retail expenditure spent at foreign stores post entry; expenditure shares of retail relative to non-retail; expenditure shares of food relative to non-food product groups within retail; and retail income shares relative to other income sources. Each row of Figure 7 equalizes one of these differences across all households in the sample, setting it at its mean level (the left panel shows the distribution of the dimension pre-equalization). We then rerun the quantification and generate the counterfactual distribution of the welfare gains from foreign entry and compare it to the actual distribution (with the distribution of both the actual and counterfactual gains shown in the right panel).

As shown in the first row of Figure 7, the richest households spend over 50 percent of their retail expenditure at foreign stores compared to just over 10 percent for the poorest households. These patterns suggest that household evaluations of store product variety and shopping amenities systematically differ across the income distribution (captured by the household-and-storespecific taste shifters $\beta_{g s h}$ and price-indices $r_{g s h}$ in Section 3.1). As is evident from the figure, equalizing this moment alone is sufficient to eradicate the regressiveness. In fact, if poor households valued the variety and amenity on offer at foreign stores as much as the rich did, the gains would actually be progressive. This finding is intuitive. The higher quality and greater product variety on offer at foreign stores, as well as their better hygiene, easier car accessibility and parking amenities are all benefits that are likely to be valued more by wealthier households. The fact that it is these households gaining most from variety and amenity gives credence to the large contribution these forces play in generating the substantial average gains we document above.

Turning to the second row of Figure 7, there is a countervailing force at play. Wealthier households spend a significantly smaller share of their total expenditure on retail consumption compared to poorer households (35 percent versus 70 percent). This force works in the opposite direction. In the absence of differences in retail expenditure shares, the gains from foreign retail entry 
would be much more regressive than we estimate.

The forces in the last two rows have much more muted effects on the distribution. The fact that poorer households spend more of their retail expenditure on food consumption contributes only very slightly to the regressiveness of the welfare gains. This is because both the pro-competitive price effect and the direct price index effect vary little across food and non-food product groups. Finally, somewhat surprisingly, differences in income sources across the income distribution do not significantly contribute to the regressiveness we find. While there are clear distributional patterns in the sectors that households obtain their income from (e.g. poorer households derive a larger proportion of their income from working in the traditional retail sector), these differences have little effect on the distribution of total gains since only a fraction of households within any given income group derive the majority of their income from the retail sector.

\subsection{Discussion}

Before concluding, we discuss several issues related to our findings above. First, we explore to what extent the results are specific to the entry of foreign retailers, rather than the entry of modern store formats more generally. Second, we relate our findings to those of the existing literature.

\subsubsection{Foreign Entry or Modern Store Formats}

To assess to what extent our findings are specific to foreign retail entry, we present two additional pieces of evidence. The first is to re-estimate the two key moments that are driving our estimated welfare effects in Table 9-price changes in pre-existing stores and post-entry store market shares-using entry events involving domestic stores with similar store formats to those of the foreign entrants. The second is to verify to what extent these two effects are present among municipalities which already had domestic modern store formats at the start of the estimation period.

For the years 2002-2006, we have data on store opening dates of all modern domestic stores. ${ }^{42}$ We define comparable domestic entry events as store openings of Mexican national retail chains whose average floor space-observed in our ANTAD dataset-is similar to that of foreign stores. Only four domestic chains-Soriana, Chedauri, Comercial Mexicana and Gigante-have both a national presence and use the big box store format used by foreign entrants. ${ }^{43}$

Figure 8 repeats the consumer price event study of Section 5.1 for the period 2002-2006, and for both foreign store entry events (Panel A) and domestic big box store entry events (Panel B). Reassuringly, the figure for foreign-retail entry is almost identical to the results in Figure 2 for the full 2002-2014 period. In contrast, when looking at comparable domestic entry events, we find no pro-competitive effect on consumer prices in pre-existing local stores.

Panels C and D of Figure 8 carry out a similar exercise but on the post-entry retail market shares analyzed in Section 5.2.1. We find that comparable domestic retailers, despite opening sim-

\footnotetext{
${ }^{42}$ Recall that after 2006, ANTAD stopped reporting the date of store openings by municipality. We obtained subsequent opening dates only for foreign-owned supermarkets.

${ }^{43}$ These are the four largest domestic retail chains in terms of average floor space and are all within 25 percent of the average floor space of foreign supermarkets. In contrast, the average floor space of the fifth largest is more than 85 percent smaller than the average floor space of foreign supermarkets.
} 
ilar sized stores, command much smaller local market shares post entry. ${ }^{44}$ Conditional on entry, the average market share of the comparable domestic retailers is less than one third of that of the foreign retailers (8.5 percent compared to 30 percent).

Finally, we explore heterogeneity in the effects of foreign-entry with respect to differences in the pre-existing level of local competition. In particular, if our results were driven by the entry of modern big box store formats, rather than specific to foreign entry, we would expect to find much weaker effects in municipalities that were already served by domestic modern big box formats. To explore this hypothesis, we allow the pro-competitive price effect of foreign entry and the post-entry foreign consumption shares to differ depending on the level of pre-existing local competition (as measured by the number of domestic big box stores per capita in 2002). As reported in online appendix Tables A.8 and A.9, we find close to zero (and insignificant) heterogeneity in the pro-competitive price effect. Post-entry foreign market shares are slightly higher (by 8.8 percent) in municipalities with low (i.e. below mean) levels of pre-existing local competition. However, this heterogeneity cannot explain the more than 20 percentage point difference in foreign and domestic post-entry market shares we document in Figure 8: even in the extreme case that foreign stores chose uncompetitive locations and domestic big box stores chose competitive ones, our heterogeneity estimates could only explain a little over a third of this gap.

Taken together, these additional exercises provide evidence that our findings are specific to the entry of foreign retailers rather than modern store formats more generally. As we discuss in Section 2.2, the literature highlights multiple differences between global retailers and their domestic competitors that underlie these results including: the use of global supply chains, logistics centered around regional distribution centers, and modern IT systems for real-time store monitoring.

\subsubsection{Relationship to the Existing Literature}

We now discuss how our findings relate to several existing literatures. First, we reiterate that our estimates complement Javorcik et al. (2008), Iacovone et al. (2015) and Javorcik and Li (2013) who find productivity gains among domestic suppliers driven by foreign retail entry. Our empirical strategy captures only productivity gains at suppliers in the municipality of entry, whereas national-level effects are absorbed by the time fixed effects. These national-level effects should be added, along with any nominal income losses to Mexican shareholders of national retail chains, in order to calculate aggregate rather than local welfare effects.

Second, given that Walmart is the most prominent of the foreign entrants in Mexico, we relate the magnitude of our effects to studies from the US that estimate the impacts of Walmart entry on some subset of employment, wages, prices, and store exit. In terms of employment and wages, this literature also finds negative impacts of Walmart's entry, but the magnitudes are substantially smaller than our estimates for Mexico in Table $6 .{ }^{45}$ In terms of price effects, Basker (2005b) doc-

\footnotetext{
${ }^{44}$ As before, we estimate average household retail expenditure shares using the consumer panel. We restrict attention to municipalities containing a foreign entrant (Panel C), or a comparable modern domestic entrant (Panel D).

${ }^{45}$ Dube et al. (2007) find county wage bills fall 1.4 percent, Neumark et al. (2008) find county retail employment falls 2.7 percent, and Ellickson and Grieco (2013) find 7 percent employment reductions for retailers within a 2 mile radius. In contrast, Basker (2005a) finds positive but small effects. These compare to a larger 7.8 percent reduction in
} 
uments city-wide price reductions of 1.5 to 3 percent due to Walmart entry, compared to the 6.6 percent reduction we find when we take the weighted average of the price changes in domestic stores and the lower prices in foreign stores. In terms of store exit, Ellickson and Grieco (2013) show that 0.15 stores shut down for every Walmart entry, substantially smaller than our finding that 3.9 percent of retail units exited due to the foreign entry event (corresponding to 80 traditional stores closing and 1 modern retailer closing in the average municipality). Finally, Hausman and Leibtag (2007), calculate the welfare gains from the arrival of Walmart Supercenters. Despite ignoring the losses from store exit and nominal incomes that we include, the welfare gains they estimate-a direct price index effect of 2.4 percent and a pro-competitive price effect of 0.06 percent-are more than 50 percent smaller than those we find.

The larger magnitudes we find are consistent with our claim in Section 2.2 that foreign retailers entering developing countries-whose retail landscapes, like Mexico's, are dominated by traditional retailers (Capizzni et al., 2012; Bronnenberg and Ellickson 2015) — constitute a more dramatic shock than expansions of companies such as Walmart within developed countries. It is also interesting to note that for example Broda et al. (2009) find that the price index implications of Walmart in the US are pro-poor whereas we find the opposite distributional pattern for Mexico, consistent with foreign retailers' targeting upper-middle class customers in the developing world.

Finally, we turn to the question of how our results relate to an off-the-shelf quantification approach using the framework of Arkolakis et al. (2012) and the extension to multinational production by Ramondo and Rodriguez-Clare (2013) (RR). To calculate RR's expression for the gains from horizontal FDI (equation 17 in RR), we require three empirical moments: the share of retail in Mexican GDP (12 percent on average in Mexico's national accounts 2002-2014), the foreign production share in Mexican retail, and the "trade elasticity" that governs how foreign production shares react to changes in FDI frictions. Assuming foreign production shares-i.e. foreign firms' share of retail value added-equal the post-entry market shares we observe in the consumer panel data (30 percent on average) and that the trade elasticity used in $R R, \theta=4.45$, holds for Mexican retail FDI, the estimated gains from foreign retail entry are: $\prod_{g \in G}\left(\left(\sum_{s \in S_{g}^{d c}} \phi_{g s h}^{1}\right)^{-\frac{1}{\theta}}\right)^{\alpha_{g h}}-1=$ $\left((0.7)^{-1 / 4.45}\right)^{0.12}-1=0.01$, or about one sixth of the gains we estimate.

There are several reasons why our numbers are higher. First, the RR approach assumes constant markups and productivity parameters, and thus abstracts from lower prices in domestic stores due to pro-competitive effects or productivity gains (that we estimate to yield a local gain of 1.6 percent). Second, while the formulas appear similar, our estimate of the direct price index effect uses a demand elasticity $\eta$ rather than a trade elasticity $\theta$, and our direct effect is scaled to account for the fact that 50 percent of expenditure is spent on retail rather than the fact that retail produces 12 percent of value added. Herrendorf et al. (2013) explore a closely related issue: why do the effects of structural change differ when estimates come from the consumption side (like ours do) and the production side (like RR's do). They conclude that it is crucial to use consumption-side elasticities when scaling by expenditure shares and production-side elasticities when scaling by value-added shares. On the consumption side, this is the elasticity of substitution across foreign local retail employment that we find for Mexico. 
and domestic stores we estimate. On the production side, this is the response of foreign production shares to changes in frictions restricting retail FDI. The elasticity used in RR is estimated off goods trade flows within a set of OECD countries (excluding Mexico), rather than production share changes in Mexican retail induced by changing FDI frictions. Our conjecture would be that the latter elasticity would be lower than $\theta=4.45$, reducing the size of the discrepancy.

\section{Conclusion}

The arrival of foreign retailers in developing countries is causing a radical transformation in the way that households source their consumption. This paper sets out to evaluate the welfare consequences of retail globalization in a developing country context. To do so, we bring to bear newly available and uniquely rich microdata that allow us to estimate a general expression of the local welfare effect of retail FDI.

We find that foreign supermarket entry leads to large and significant welfare gains for the average household. The majority of these gains come from a significant reduction in the cost of living. About a quarter of this reduction is driven by reductions in prices at domestic stores, with the remainder coming from the consumer gains due to the lower prices, new product variety and different shopping amenities offered by foreign retailers. In contrast, on the nominal income side we find no evidence of average income or employment effects. We do, however, find evidence of domestic store exit as well as employment, labor income, and profit declines in the traditional retail sector. Exploring the distribution of these gains from retail FDI, we find that while all income groups experience significant gains on average, these gains are 50 percent larger for the richest income group compared to the poorest, primarily because of the greater valuation wealthy households place on the product variety and shopping amenities on offer at foreign stores.

Our analysis provides a number of insights that relate to ongoing debates about developing country policies towards retail FDI. Our findings suggest that these debates may focus too little on the potential for reductions in the cost of living that benefit the vast majority of households, both those who end up shopping at the foreign retailer and those who enjoy price reductions at domestic retailers. Instead they commonly focus on the potentially adverse effects for an important, but nevertheless select group of households working in the traditional retail sector. The empirical evidence suggests that while these adverse nominal income effects are present, they are swamped at the local level by reductions in the cost of living that give rise to real income gains across all household income groups. 


\section{References}

Anderson, S. P., De Palma, A., \& Thisse, J. F. (1992). Discrete choice theory of product differentiation. MIT press.

Arkolakis, C., Costinot, A., \& Rodríguez-Clare, A. (2012). New trade models, same old gains? American Economic Review, 102(1), 94-130.

Atkin, D. (2013). Trade, tastes and nutrition in India. American Economic Review, 103(5), 1629-1663.

Banco de Mexico. (2002). Metodología para el cambio de base del INPC.

Basker, E. (2005a). Job creation or destruction? Labor market effects of Wal-Mart expansion. Review of Economics and Statistics, 87(1), 174-183.

Basker, E. (2005b). Selling a cheaper mousetrap: Wal-mart's effect on retail prices. Journal of Urban Economics, 58, 203-229.

Beraja, M., Hurst, E., \& Ospina, J. (2014). The regional evolution of prices and wages during the great recession. mimeo, University of Chicago.

Biles, J. J. (2008). Wal-Mart and the supermarket revolution in Mexico. Geographische Rundschau International Edition, 4(2), 44-49.

Broda, C., Leibtag, E., \& Weinstein, D. (2009). The role of prices in measuring the poor's living standards. The Journal of Economic Perspectives, 23(2), 77-97.

Broda, C., \& Weinstein, D. E. (2006). Globalization and the gains from variety. Quarterly Journal of Economics, 121(2), 541-585.

Bronnenberg, B. J., \& Ellickson, P. B. (2015). Adolescence and the path to maturity in global retail. Journal of Economic Perspectives, 29(4), 113-134.

Busso, M., Fazio, M. V., \& Levy, S. (2012). (In)formal and (un)productive: The productivity costs of excessive informality in Mexico. IDB Working Paper 341, 1-53.

Capizzani, M., Ramirez Huerta, F., \& Rocha e Oliveira, P. (2012). Retail in latin america: Trends, challenges and opportunities. IESE working paper 170.

Caron, J., Fally, T., \& Markusen, J. R. (2012). Skill premium and trade puzzles: A solution linking production and preferences. NBER Working Paper 18131.

Deaton, A. (1989). Rice prices and income distribution in Thailand: A non-parametric analysis. Economic Journal, 99(395), 1-37.

Deaton, A., \& Tarozzi, A. (2000). Prices and poverty in India. Princeton University Press.

DellaVigna, S., \& Gentzkow, M. (2015). Uniform pricing in retail: A key fact, but why? mimeo, University of California at Berkeley.

Deloitte Consulting. (2014). Global powers of retail 2014.

Donaldson, D. (in press). Railroads of the raj: Estimating the impact of transportation infrastructure. American Economic Review.

Dube, A., Lester, T. W., \& Eidlin, B. (2007). Firm entry and wages: Impact of Wal-Mart growth on earnings throughout the retail sector. IRLE Working paper 126-05.

Dufey, A., Grieg-Gran, M., \& Ward, H. (2008). Responsible enterprise, foreign direct investment and 
investment promotion: Key issues in attracting investment for sustainable development. International Institute for Environment and Development.

Einav, L., Levin, J., \& Klenow, P. (2015). The importance of customer relationships for U.S. retailer size and growth. ASSA 2015 Unpublished Conference Manuscript.

Ellickson, P. B., \& Grieco, P. L. (2013). Wal-Mart and the geography of grocery retailing. Journal of Urban Economics, 75, 1-14.

Faber, B. (2014). Trade liberalization, the price of quality, and inequality: Evidence from Mexican store prices. UC-Berkeley Working Paper.

Fajgelbaum, P. D., \& Khandelwal, A. K. (2014). Measuring the unequal gains from trade. UCLA Working Paper.

Feenstra, R. C. (1994). New product varieties and the measurement of international prices. American Economic Review, 84(1), 155-57.

Feenstra, R. C., \& Weinstein, D. E. (in press). Globalization, markups and U.S. welfare. Journal of Political Economy.

Goldberg, P., \& Pavcnik, N. (2007). Distributional effects of globalization in developing countries. Journal of Economic Literature, 45, 39-82.

Handbury, J., \& Weinstein, D. E. (in press). Goods prices and availability in cities. Review of Economics Studies.

Hausman, J., \& Leibtag, E. (2007). Consumer benefits from increased competition in shopping outlets: Measuring the effect of Wal-Mart. Journal of Applied Econometrics, 22(7), 1157-1177.

Hausman, J. A. (1996). Valuation of new goods under perfect and imperfect competition. In The economics of new goods (pp. 207-248). University of Chicago Press.

Hausman, J. A., \& Leonard, G. K. (2002). The competitive effects of a new product introduction: A case study. Journal of Industrial Economics, 50(3), 237-263.

Herrendorf, B., Rogerson, R., \& Valentinyi, A. (2013). Two perspectives on preferences and structural transformation. American Economic Review, 103(7), 2752-2789.

Hicks, J. R. (1940). The valuation of the social income. Economica, 105-124.

Holmes, T. J. (2011). The diffusion of Wal-Mart and economies of density. Econometrica, 79(1), 253-302.

Horowitz, J. L. (2001). The bootstrap. In J. J. Heckman \& E. Leamer (Eds.), Handbook of econometrics (Vol. 5, p. 3159 - 3228). Elsevier.

Humphrey, J. (2007). The supermarket revolution in developing countries: Tidal wave or tough competitive struggle? Journal of Economic Geography, 7(4), 433-450.

Iacovone, L., Javorcik, B. S., Keller, W., \& Tybout, J. R. (2015). Supplier responses to Wal-Mart's invasion in Mexico. Journal of International Economics, 95(1), 1 - 15.

Instituto Nacional de Estadística y Geografía - INEGI. (2009). Metodología de los censos económicos.

Instituto Nacional de Estadística y Geografía - INEGI. (2010). Indice nacional de precios al consumidor: Ano base segunda quincena diciembre 2010 con ponderadores ENGIH 2008: Documento metodológico. 
J. A. John, N. R. D. (1980). An alternative family of transformations. Journal of the Royal Statistical Society. Series C (Applied Statistics), 29(2), 190-197.

Javorcik, B., Keller, W., \& Tybout, J. R. (2008). Openness and industrial response in a Wal-Mart world: A case study of mexican soaps, detergents and surfactant producers. World Economy, 31(12), 1558 - 1580.

Javorcik, B. S., \& Li, Y. (2013). Do the biggest aisles serve a brighter future? Global retail chains and their implications for Romania. Journal of International Economics, 90(2), 348-363.

Jia, P. (2008). What happens when Wal-Mart comes to town: An empirical analysis of the discount retailing industry. Econometrica, 76(6), 1263-1316.

Krugman, P. (1980). Scale economies, product differentiation, and the pattern of trade. American Economic Review, 70(5), 950-59.

Lagakos, D. (in press). Explaining cross-country productivity differences in retail trade. Journal of Political Economy.

Neumark, D., Zhang, J., \& Cicarella, S. (2008). The effects of Wal-Mart on local labor markets. Journal of urban Economics, 63, 405-430.

Porto, G. (2006). Using survey data to assess the distributional effects of trade policy. Journal of International Economics, 70(1), 140-160.

Ramondo, N., \& Rodríguez-Clare, A. (2013). Trade, multinational production, and the gains from openness. Journal of Political Economy, 121(2), 273-322.

Reardon, T., Timmer, C. P., Barrett, C. B., \& Berdegué, J. (2003). The rise of supermarkets in Africa, Asia, and Latin America. American Journal of Agricultural Economics, 85(5), 1140-1146.

Salas, J. (2006). Price index measurement in Mexico. IFC Bulletin No 24: Irvin Fisher Committee on Central Bank Statistics, 62-68.

Topalova, P. (2010). Factor immobility and regional impacts of trade liberalization: Evidence on poverty from India. American Economic Journal: Applied Economics, 2(4), 1-41.

Varela, M. (2013). The costs of growth: Estimating entry costs during rollouts. University of Arizona Working Paper.

Wrigley, N., \& Lowe, M. (2010). The globalization of trade in retail services. Organisation for Economic Co-operation and Development. 


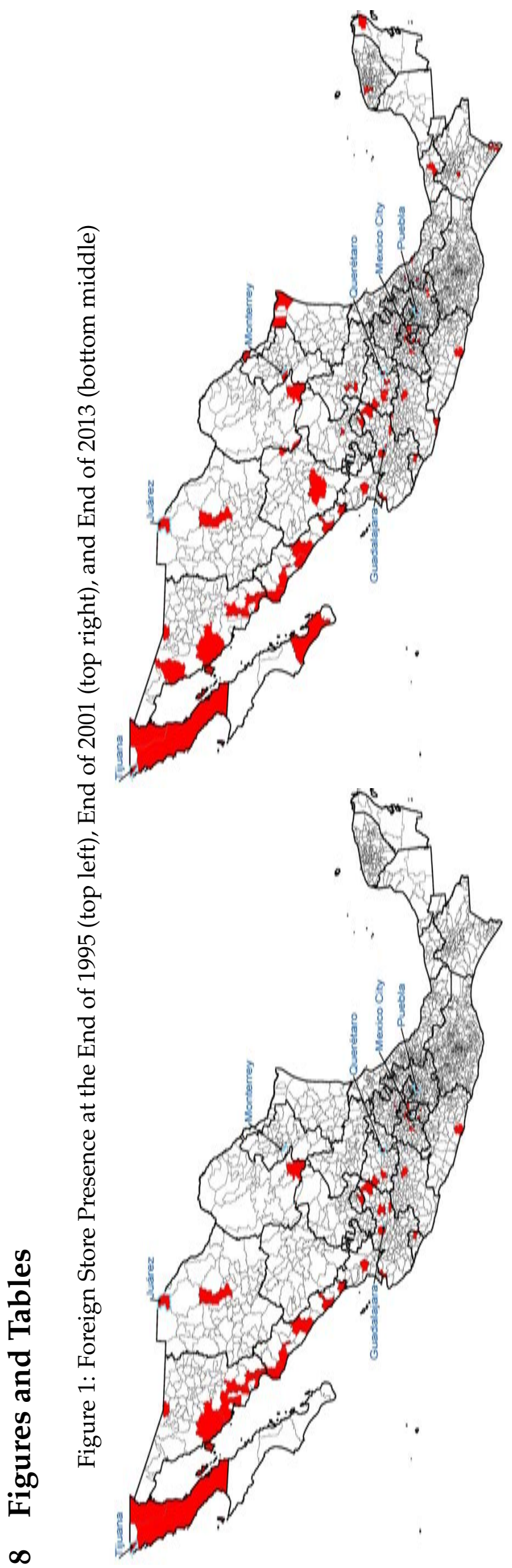

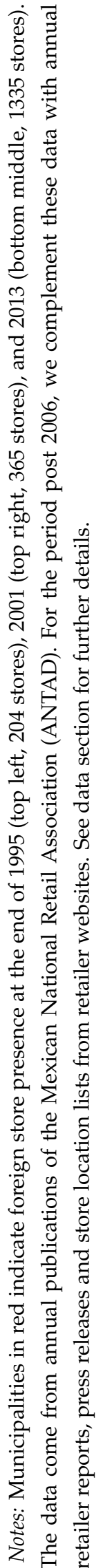



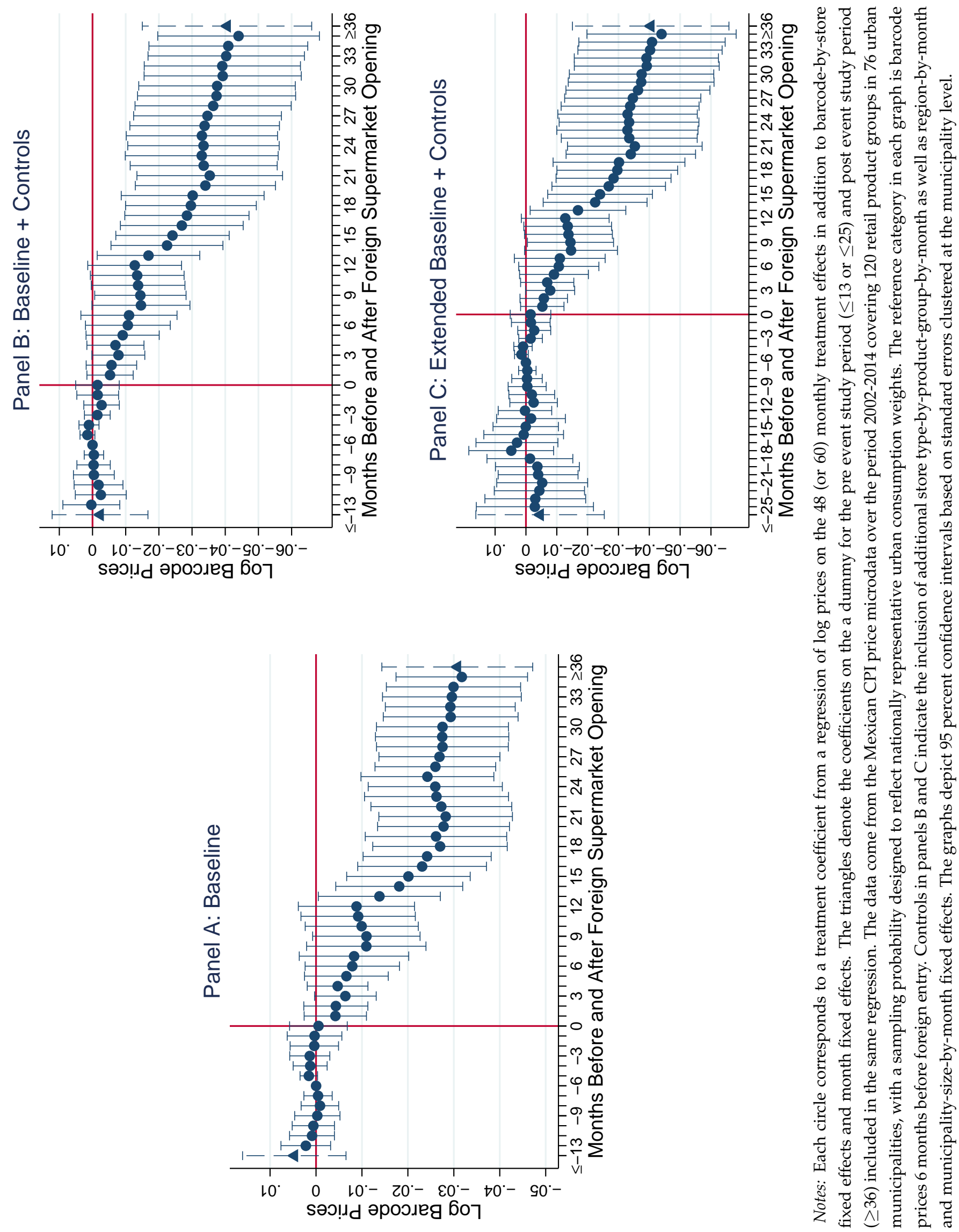
Figure 3: Foreign Retail Market Shares Post Entry
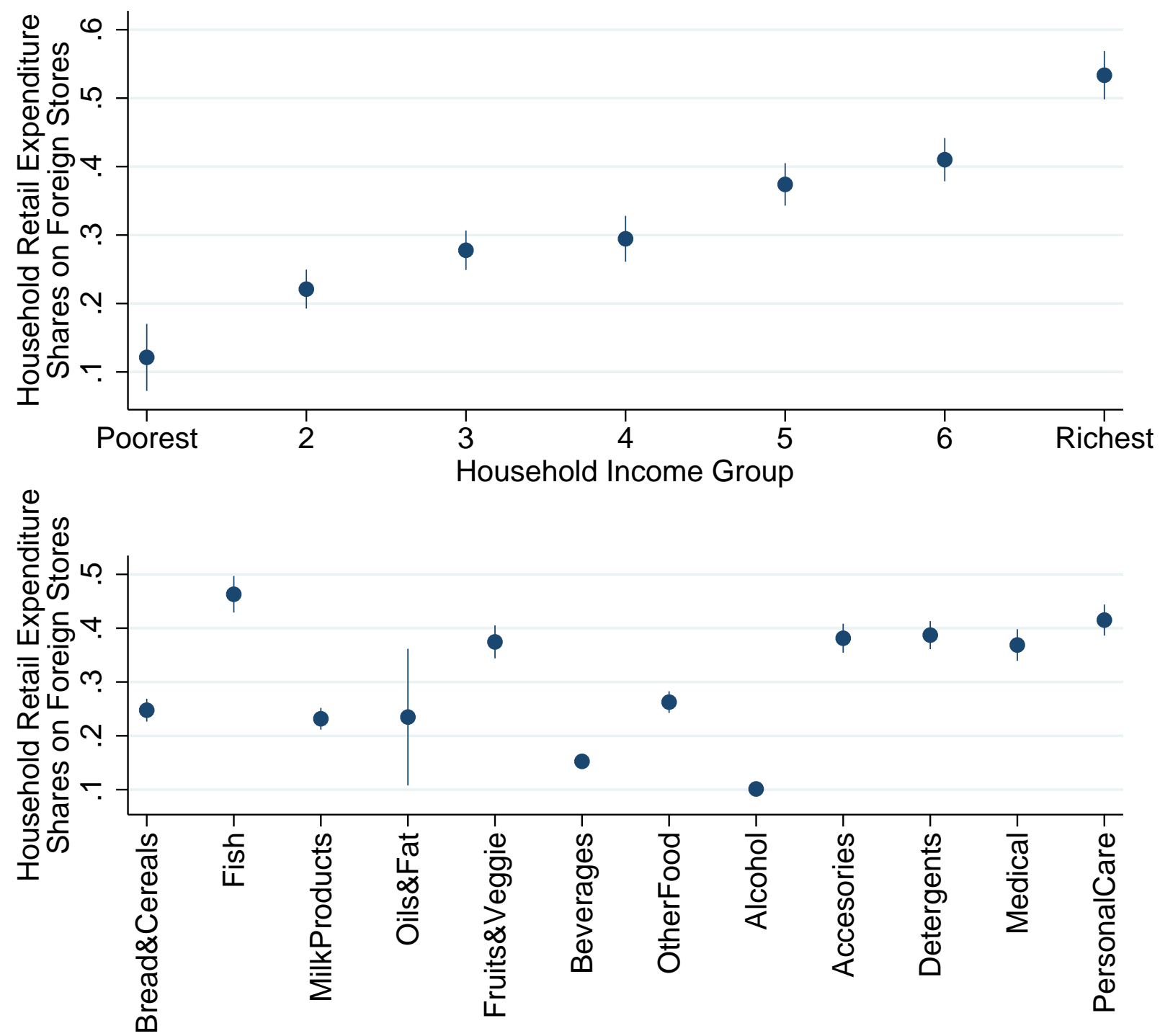

Notes: The graphs plot the share of household retail expenditure spent at foreign stores. The data come from the Mexican consumer panel microdata for the years 2011-14. We restrict attention to municipalities where the first foreign store entered more than two years previously. Expenditure shares are weighted by household survey weights. Both graphs depict 95\% confidence intervals based on standard errors clustered at the municipality level. 

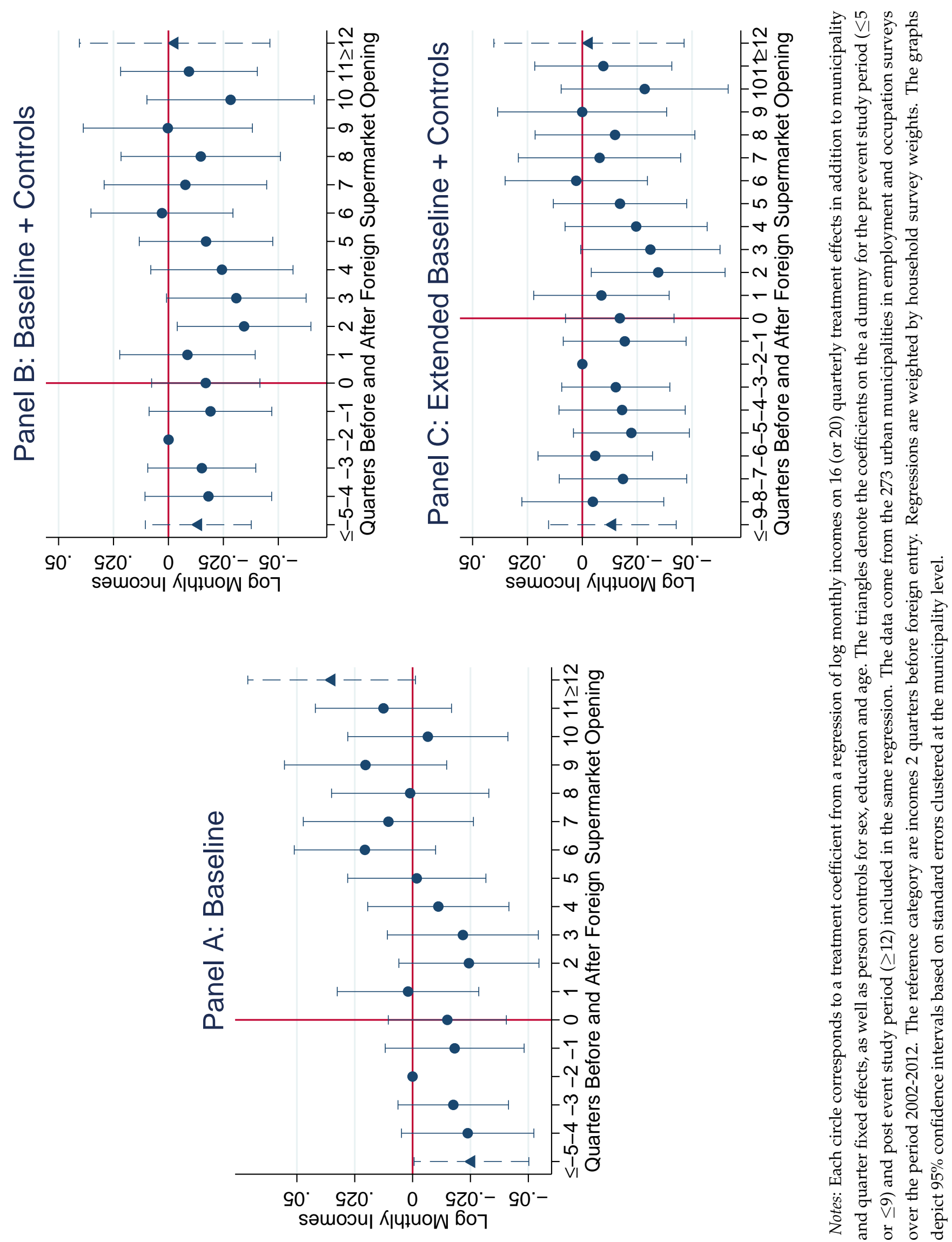

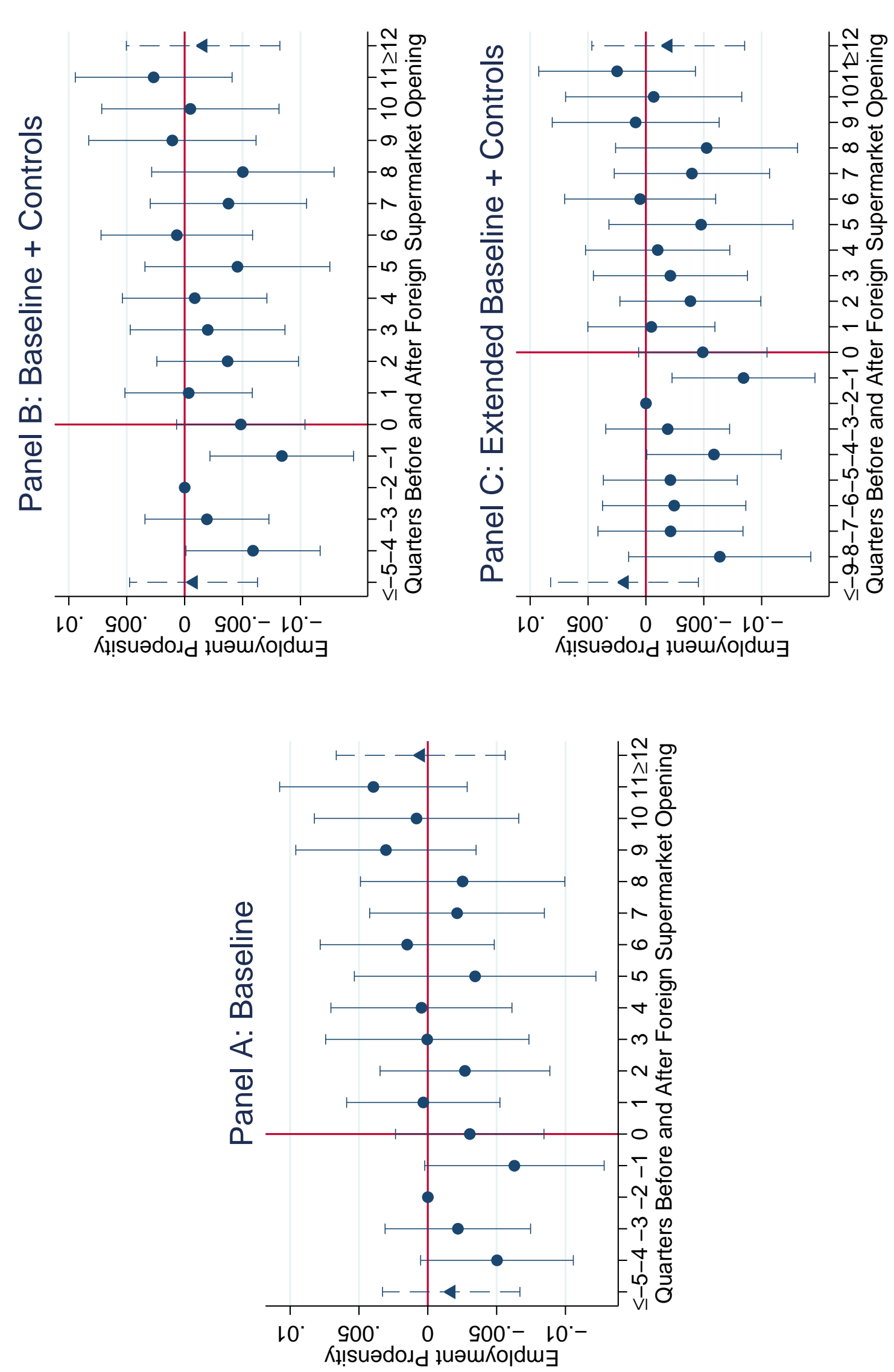
Figure 6: Gains from Foreign Retail Entry across the Household Income Distribution
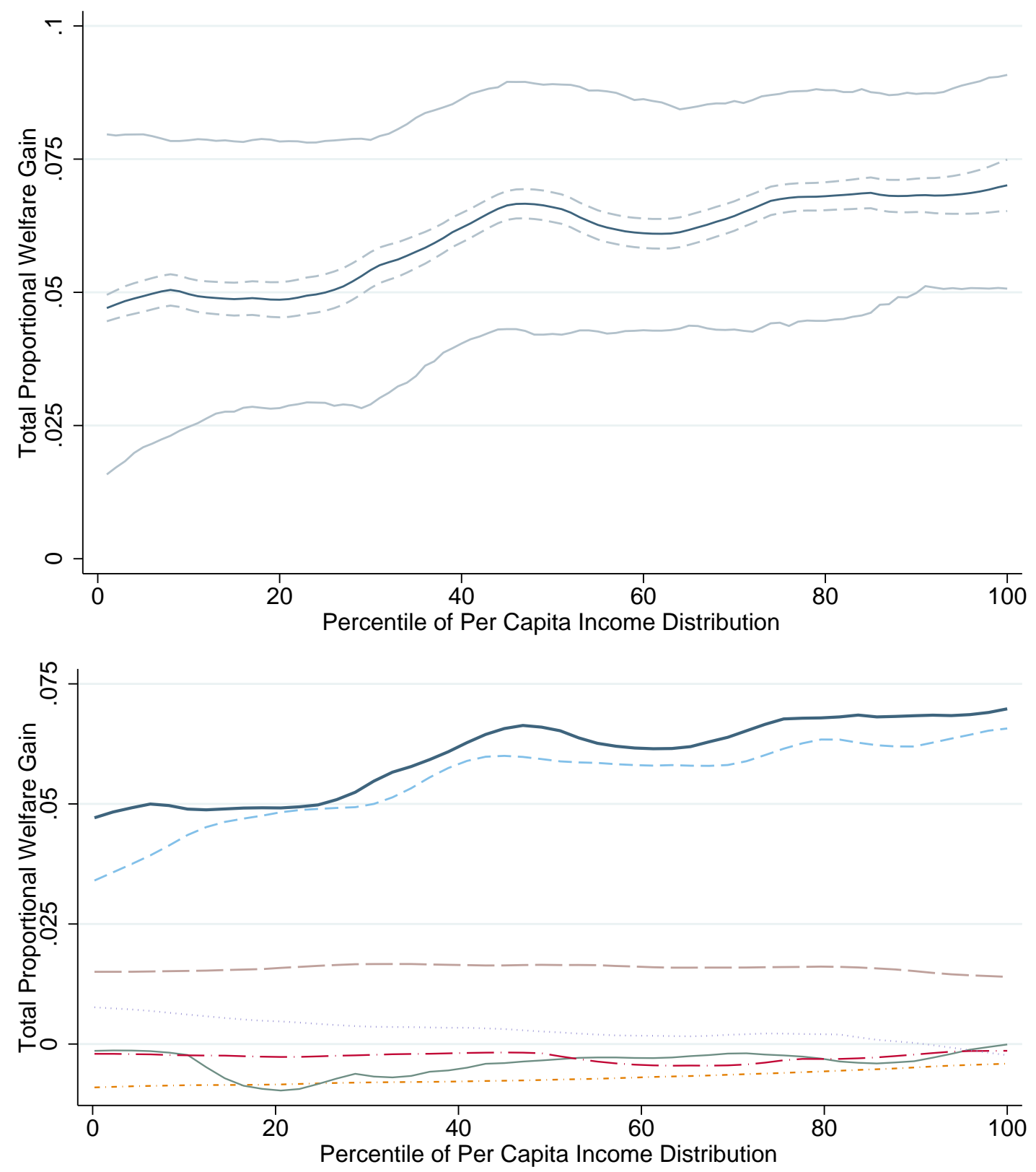

Total Welfare Gains ---- Direct Price Index
Pro-Competitive Exit --- Pro-Competitive Price
Other Income

Notes: The graphs are non-parametric plots of the household gains from foreign retail entry against the pre-entry location in the income distribution. Gains calculated from the quantification exercise described in Section 6 using the exact under CES approach. Pre-entry incomes as well as household-level income and expenditure shares come from the 12,293 households in the income and expenditure surveys that reside in the 240 urban municipalities that had not yet experienced foreign retail entry at the time of the survey. The upper panel depicts two sets of confidence intervals: The solid gray lines are the 95 percentile envelope of the non-parametric plots for each of the 1000 bootstraps described in Section 6. The tighter dashed lines are the 95 percentile confidence interval that just takes account of sampling variation across households in the income and expenditure survey. The lower panel decomposes the total gains into its constituent parts. Plots are weighted by household survey weights. 


\section{Figure 7: Counterfactual Distributions of the Gains}
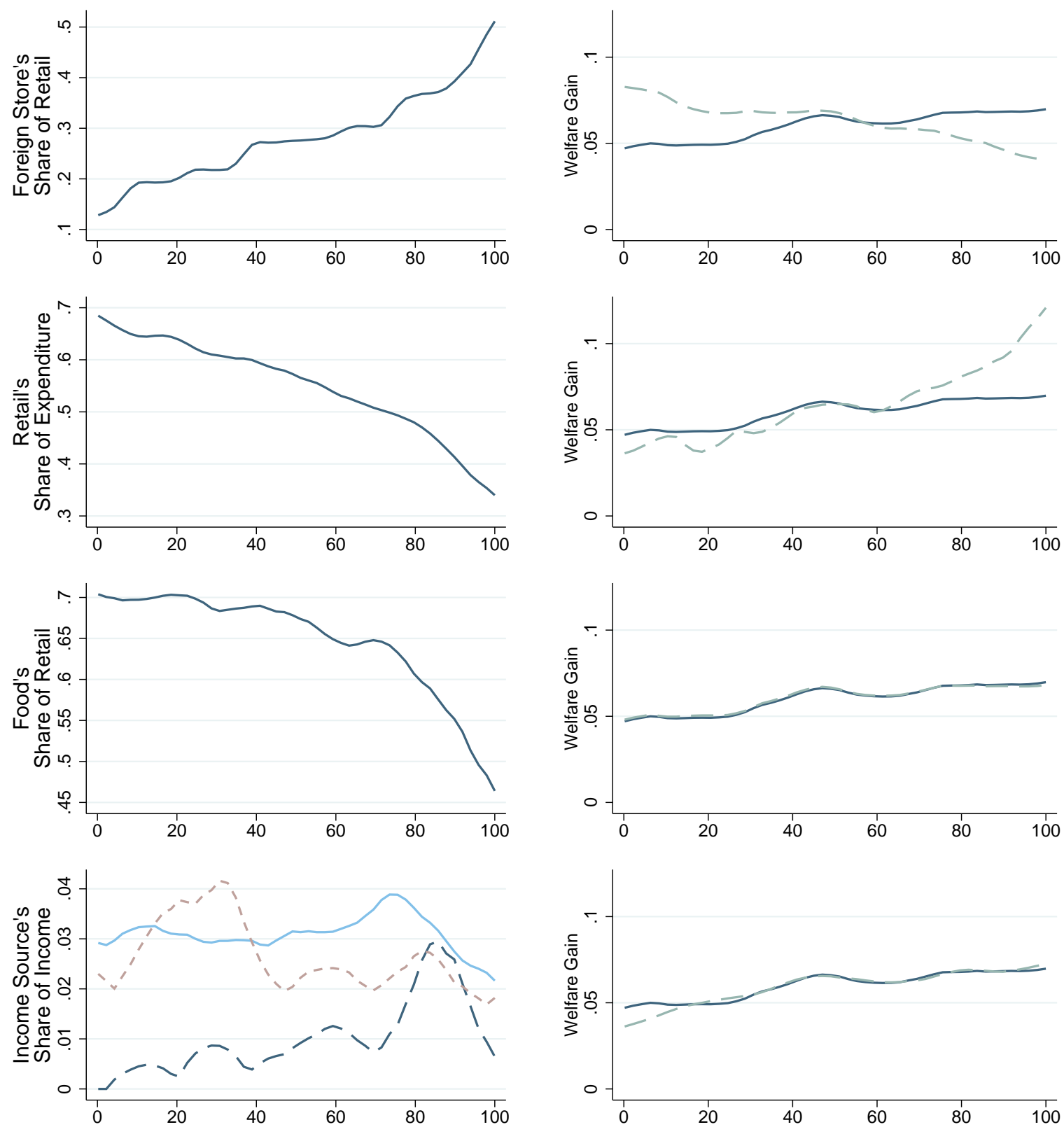

Percentile of Per Capita Income Distribution

Percentile of Per Capita Income Distribution

- - Retail Modern $=-$ - Retail Trad. $\quad$ Retail Self-Employ.

Actual Welfare - - Counterfactual Welfare

Notes: This figure explores the role of differences along several shopping and income dimensions in explaining the regressive total welfare effects we find using the exact under CES approach. Each row explores a different dimension (foreign retail shares, retail's share of total expenditure, the food share of retail, and retail income shares). The left panels plot the distribution of this dimension in the data. The right panel plots with a dashed line the counterfactual distribution of gains if this dimension was equalized across households at its mean (alongside the actual distribution displayed with a solid line). Pre-entry incomes as well as household-level income and expenditure shares come from the 12,293 households in the income and expenditure surveys that reside in the 240 urban municipalities that had not yet experienced foreign retail entry at the time of the survey. Plots are weighted by household survey weights. 

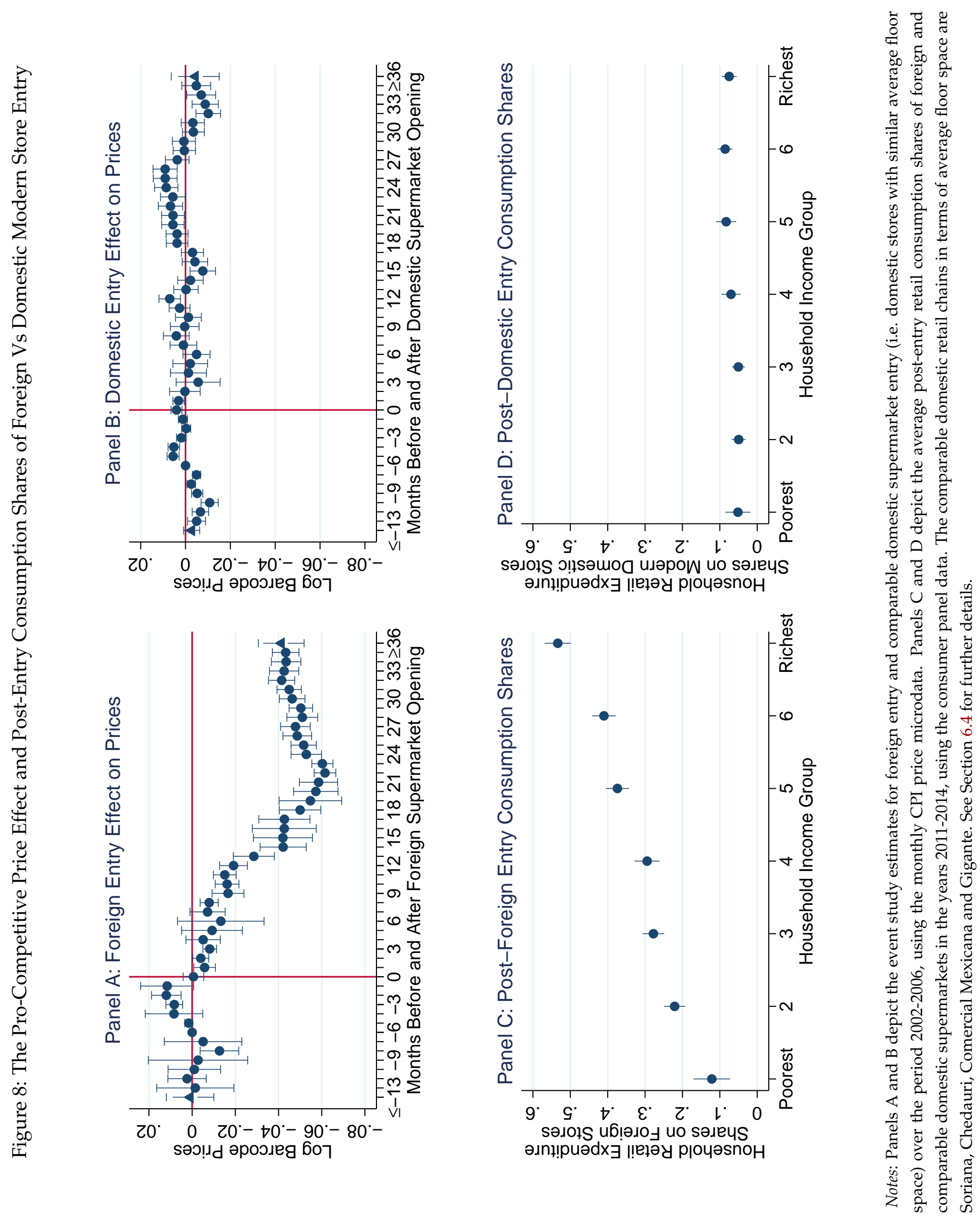


\section{Tables}

Table 1: How Do Foreign Owned Supermarkets Differ Ex Post?

\begin{tabular}{|c|c|c|c|c|}
\hline Dependent Variable: & $\begin{array}{c}\text { (1) } \\
\text { Log Price }\end{array}$ & $\begin{array}{c}\text { (2) } \\
\text { Log Price }\end{array}$ & $\begin{array}{c}(3) \\
\text { Log Number of } \\
\text { Barcodes } \\
\end{array}$ & $\begin{array}{c}\text { (4) } \\
\text { Log Floor Space }\end{array}$ \\
\hline Foreign Store Dummy & $\begin{array}{c}-0.118 * * * \\
(0.00913)\end{array}$ & $\begin{array}{c}0.249 * * * \\
(0.0160)\end{array}$ & $\begin{array}{c}1.612 * * * \\
(0.0671)\end{array}$ & $\begin{array}{c}1.911^{* * *} \\
(0.0416)\end{array}$ \\
\hline Municipality-By-Year FX & $\checkmark$ & $\checkmark$ & $\checkmark$ & $\checkmark$ \\
\hline Municipality-By-Product-By-Month FX & $\checkmark$ & $\checkmark$ & $x$ & $x$ \\
\hline Municipality-By-Barcode-By-Month FX & $\checkmark$ & $x$ & $x$ & $x$ \\
\hline Observations & $18,659,777$ & $18,659,777$ & 10,393 & 11,113 \\
\hline R-squared & 0.923 & 0.368 & 0.139 & 0.302 \\
\hline Number of Municipalities & 151 & 151 & 151 & 499 \\
\hline
\end{tabular}

Notes: Table reports the coefficient from regressing log prices, log number of barcodes or log floor space on a foreign store dummy. Columns 1-2 are based the Mexican consumer panel microdata for the years 2011-14, and compare foreign-owned supermarkets to all types of domestic retail establishments (traditional and modern) either with or without barcode-level fixed effects. Column 3 also uses the consumer panel to compare the number of barcode products sold in foreign stores to modern domestic retailers (domestic supermarkets or big box stores). Column 4 is based on ANTAD data on establishment floor space and again compares foreign-owned supermarkets to modern domestic retailers. Regressions using the consumer panel data are weighted by household survey weights. Standard errors are clustered at the municipality level and reported in parentheses. ${ }^{*} 10 \%, * * 5 \%, * * 1 \%$ significance levels. 
Table 2: Effect on the Prices of Domestic Retailers

\begin{tabular}{|c|c|c|c|c|c|}
\hline Dependent Variable: & $\begin{array}{c}(1) \\
\text { Log Price }\end{array}$ & $\begin{array}{c}(2) \\
\text { Log Price }\end{array}$ & Log Price & $\begin{array}{c}(4) \\
\text { Log Price } \\
\text { (Non-Retail) } \\
\end{array}$ & $\begin{array}{c}\text { (5) } \\
\text { Log Price } \\
\text { (Non-Retail) }\end{array}$ \\
\hline Foreign Entry - More Than Four Quarters Before (Unbalanced) & $\begin{array}{c}0.00378 \\
(0.00612)\end{array}$ & $\begin{array}{c}-0.00311 \\
(0.00719)\end{array}$ & $\begin{array}{c}-0.00412 \\
(0.00716)\end{array}$ & $\begin{array}{c}0.00254 \\
(0.00512)\end{array}$ & $\begin{array}{c}0.00112 \\
(0.00689)\end{array}$ \\
\hline Foreign Entry - Four Quarters Before & $\begin{array}{l}0.000274 \\
(0.00231)\end{array}$ & $\begin{array}{l}-0.00217 \\
(0.00358)\end{array}$ & $\begin{array}{l}-0.00343 \\
(0.00325)\end{array}$ & $\begin{array}{c}0.00403 \\
(0.00338)\end{array}$ & $\begin{array}{c}0.00974 \\
(0.00640)\end{array}$ \\
\hline Foreign Entry - Three Quarters Before & $\begin{array}{l}-0.00146 \\
(0.00227)\end{array}$ & $\begin{array}{l}-0.00119 \\
(0.00217)\end{array}$ & $\begin{array}{l}-0.00208 \\
(0.00200)\end{array}$ & $\begin{array}{l}0.00841^{* *} \\
(0.00408)\end{array}$ & $\begin{array}{l}0.00971^{*} \\
(0.00489)\end{array}$ \\
\hline Foreign Entry - Two Quarters Before (Omitted) & $\begin{array}{c}0 \\
(0)\end{array}$ & $\begin{array}{c}0 \\
(0)\end{array}$ & $\begin{array}{c}0 \\
(0)\end{array}$ & $\begin{array}{c}0 \\
(0)\end{array}$ & $\begin{array}{c}0 \\
(0)\end{array}$ \\
\hline Foreign Entry - One Quarter Before & $\begin{array}{r}-0.000276 \\
(0.00199)\end{array}$ & $\begin{array}{l}-0.00271 \\
(0.00195)\end{array}$ & $\begin{array}{l}-0.00257 \\
(0.00192)\end{array}$ & $\begin{array}{l}-0.00108 \\
(0.00371)\end{array}$ & $\begin{array}{c}0.00210 \\
(0.00493)\end{array}$ \\
\hline Foreign Entry - One Quarter After & $\begin{array}{l}-0.00396 \\
(0.00290)\end{array}$ & $\begin{array}{l}-0.00504 \\
(0.00308)\end{array}$ & $\begin{array}{l}-0.00495 \\
(0.00310)\end{array}$ & $\begin{array}{l}0.00733 \\
(0.00509)\end{array}$ & $\begin{array}{c}0.00971 \\
(0.00836)\end{array}$ \\
\hline Foreign Entry - Two Quarters After & $\begin{array}{c}-0.00684 * * \\
(0.00311)\end{array}$ & $\begin{array}{c}-0.00871^{* *} \\
(0.00402)\end{array}$ & $\begin{array}{c}-0.00877^{* *} \\
(0.00405)\end{array}$ & $\begin{array}{l}0.00975^{*} \\
(0.00533)\end{array}$ & $\begin{array}{c}0.00882 \\
(0.00622)\end{array}$ \\
\hline Foreign Entry - Three Quarters After & $\begin{array}{l}-0.00999^{*} \\
(0.00566)\end{array}$ & $\begin{array}{c}-0.0129^{*} \\
(0.00690)\end{array}$ & $\begin{array}{l}-0.0133^{*} \\
(0.00696)\end{array}$ & $\begin{array}{c}0.00266 \\
(0.00456)\end{array}$ & $\begin{array}{c}0.00160 \\
(0.00326)\end{array}$ \\
\hline Foreign Entry - Four Quarters After & $\begin{array}{c}-0.0110^{*} \\
(0.00589)\end{array}$ & $\begin{array}{l}-0.0147 * * \\
(0.00685)\end{array}$ & $\begin{array}{c}-0.0152^{* *} \\
(0.00689)\end{array}$ & $\begin{array}{c}-0.000294 \\
(0.00594)\end{array}$ & $\begin{array}{c}0.00101 \\
(0.00668)\end{array}$ \\
\hline Foreign Entry - Five Quarters After & $\begin{array}{c}-0.0145^{* *} \\
(0.00624)\end{array}$ & $\begin{array}{l}-0.0181 * * \\
(0.00743)\end{array}$ & $\begin{array}{l}-0.0190^{* *} \\
(0.00732)\end{array}$ & $\begin{array}{c}0.00739 \\
(0.00634)\end{array}$ & $\begin{array}{c}0.00717 \\
(0.00890)\end{array}$ \\
\hline Foreign Entry - Six Quarters After & $\begin{array}{c}-0.0234 * * * \\
(0.00654)\end{array}$ & $\begin{array}{c}-0.0273 * * * \\
(0.00870)\end{array}$ & $\begin{array}{c}-0.0283^{* * *} \\
(0.00844)\end{array}$ & $\begin{array}{c}0.00636 \\
(0.00694)\end{array}$ & $\begin{array}{c}0.00232 \\
(0.00812)\end{array}$ \\
\hline Foreign Entry - Seven Quarters After & $\begin{array}{c}-0.0278^{* * *} \\
(0.00708)\end{array}$ & $\begin{array}{c}-0.0320^{* * * *} \\
(0.0101)\end{array}$ & $\begin{array}{c}-0.0330^{* * * *} \\
(0.00986)\end{array}$ & $\begin{array}{l}-0.00182 \\
(0.00732)\end{array}$ & $\begin{array}{l}-0.00684 \\
(0.00747)\end{array}$ \\
\hline Foreign Entry - Eight Quarters After & $\begin{array}{c}-0.0281 * * * \\
(0.00738)\end{array}$ & $\begin{array}{c}-0.0347 * * * \\
(0.0109)\end{array}$ & $\begin{array}{c}-0.0354 * * * \\
(0.0107)\end{array}$ & $\begin{array}{l}-0.00145 \\
(0.00921)\end{array}$ & $\begin{array}{r}-0.00450 \\
(0.0107)\end{array}$ \\
\hline Foreign Entry - Nine Quarters After & $\begin{array}{c}-0.0263 * * * \\
(0.00687)\end{array}$ & $\begin{array}{c}-0.0341 * * * \\
(0.0112)\end{array}$ & $\begin{array}{c}-0.0341 * * * \\
(0.0110)\end{array}$ & $\begin{array}{c}0.0103 \\
(0.0101)\end{array}$ & $\begin{array}{l}0.00635 \\
(0.0124)\end{array}$ \\
\hline Foreign Entry - Ten Quarters After & $\begin{array}{c}-0.0282 * * * \\
(0.00694)\end{array}$ & $\begin{array}{c}-0.0369 * * * \\
(0.0115)\end{array}$ & $\begin{array}{c}-0.0362 * * * \\
(0.0112)\end{array}$ & $\begin{array}{c}0.0144 \\
(0.0108)\end{array}$ & $\begin{array}{l}0.00508 \\
(0.0114)\end{array}$ \\
\hline Foreign Entry - Eleven Quarters After & $\begin{array}{c}-0.0296 * * * \\
(0.00704) \\
\end{array}$ & $\begin{array}{c}-0.0393 * * * \\
(0.0117) \\
\end{array}$ & $\begin{array}{c}-0.0385 * * * \\
(0.0113) \\
\end{array}$ & $\begin{array}{l}0.00981 \\
(0.0114) \\
\end{array}$ & $\begin{array}{r}-0.00168 \\
(0.0111) \\
\end{array}$ \\
\hline Foreign Entry - Twelve Quarters After & $\begin{array}{c}-0.0313^{* * *} \\
(0.00727)\end{array}$ & $\begin{array}{c}-0.0425^{* * *} \\
(0.0119)\end{array}$ & $\begin{array}{c}-0.0414^{* * *} \\
(0.0115)\end{array}$ & $\begin{array}{c}0.0111 \\
(0.0133)\end{array}$ & $\begin{array}{l}0.00117 \\
(0.0135)\end{array}$ \\
\hline Foreign Entry - More Than Twelve Quarters After (Unbalanced) & $\begin{array}{c}-0.0316^{* * * *} \\
(0.00835)\end{array}$ & $\begin{array}{c}-0.0412 * * * \\
(0.0127)\end{array}$ & $\begin{array}{c}-0.0392 * * * \\
(0.0119)\end{array}$ & $\begin{array}{c}0.0248 \\
(0.0162)\end{array}$ & $\begin{array}{c}0.0121 \\
(0.0160)\end{array}$ \\
\hline P-Value (Post 3 Years = 12 Quarters After) & 0.941 & 0.744 & 0.548 & 0.0077 & 0.057 \\
\hline Month FX & $\checkmark$ & $\checkmark$ & $\checkmark$ & $\checkmark$ & $\checkmark$ \\
\hline Barcode-By-Store FX & $\checkmark$ & $\checkmark$ & $\checkmark$ & $\checkmark$ & $\checkmark$ \\
\hline Product Group-By-Store Type-By-Month FX & $x$ & $\checkmark$ & $\checkmark$ & $x$ & $\checkmark$ \\
\hline Region-By-Month FX & $x$ & $\checkmark$ & $\checkmark$ & $x$ & $\checkmark$ \\
\hline Municipality Size-By-Month FX & $x$ & $\checkmark$ & $\checkmark$ & $x$ & $\checkmark$ \\
\hline Control for Local Government Expenditure & $x$ & $x$ & $\checkmark$ & $x$ & $\checkmark$ \\
\hline Observations & $3,228,544$ & $2,850,238$ & $2,560,558$ & $1,581,115$ & $1,321,733$ \\
\hline R-squared & 0.996 & 0.996 & 0.996 & 0.997 & 0.997 \\
\hline Barcode-By-Store Cells & 149,273 & 124,466 & 114,207 & 42,715 & 34,877 \\
\hline Store Type-By-Product-By-Month Cells & 33,516 & 33,516 & 32,790 & 8,186 & 8,027 \\
\hline Region-By-Month Cells & 705 & 705 & 690 & 705 & 690 \\
\hline Municipality Size-By-Month Cells & 705 & 705 & 690 & 705 & 690 \\
\hline Municipality Clusters & 76 & 76 & 65 & 90 & 65 \\
\hline
\end{tabular}

Notes: Table reports regressions of log prices at domestic stores on 16 quarters-since-foreign-entry treatment effects and 2 pre and post event study dummies. Data come from the CPI price microdata for the period 2002-14 covering 120 retail product groups and 76 urban municipalities, with a sampling probability designed to reflect nationally representative urban consumption weights. The dependent variable is the log price for unique barcode-by-store combinations. Foreign Entry indicates the first presence of a foreign supermarket in the municipality. Regressions include different sets of fixed effects and additional controls as indicated in the table. The final columns show results on non-retail CPI price quotes including transportation, housing, education, health and other services. Barcode-by-store fixed effects in that column refer to item-purveyor identifiers that enumerators track over time (e.g. a hair cut from the same hairdresser or a taxi ride on the same route from the same taxi company). Standard errors are clustered at the municipality level and reported in parentheses. ${ }^{*} 10 \%,{ }^{* *} 5 \%,{ }^{* * *} 1 \%$ significance levels. 
Table 3: Effect on the Prices of Domestic Retailers - Heterogeneity

\begin{tabular}{|c|c|c|c|c|}
\hline Dependent Variable: & $\begin{array}{c}(1) \\
\text { Log Price }\end{array}$ & $\begin{array}{c}(2) \\
\text { Log Price }\end{array}$ & $\begin{array}{c}(3) \\
\text { Log Price } \\
\end{array}$ & $\begin{array}{c}(4) \\
\text { Log Price }\end{array}$ \\
\hline Foreign Entry & $\begin{array}{c}-0.0373 * * * \\
(0.0119)\end{array}$ & & & \\
\hline Foreign Entry X Food & & $\begin{array}{c}-0.0395 * * * \\
(0.0137)\end{array}$ & & \\
\hline Foreign Entry X Non-Food & & $\begin{array}{c}-0.0362 * * \\
(0.0154)\end{array}$ & & \\
\hline Foreign Entry X Traditional Store & & & $\begin{array}{l}-0.0235 \\
(0.0198)\end{array}$ & \\
\hline Foreign Entry X Modern Store & & & $\begin{array}{c}-0.0526^{* * *} \\
(0.0169)\end{array}$ & \\
\hline Foreign Entry X Food X Traditional Store & & & & $\begin{array}{r}-0.00425 \\
(0.0162)\end{array}$ \\
\hline Foreign Entry X Non-Food X Traditional Store & & & & $\begin{array}{l}-0.0287 \\
(0.0231)\end{array}$ \\
\hline Foreign Entry X Food X Modern Store & & & & $\begin{array}{c}-0.0559 * * * \\
(0.0169)\end{array}$ \\
\hline Foreign Entry X Non-Food X Modern Store & & & & $\begin{array}{c}-0.0497^{*} \\
(0.0255)\end{array}$ \\
\hline Barcode-By-Store FX & $\checkmark$ & $\checkmark$ & $\checkmark$ & $\checkmark$ \\
\hline Product-By-Store Type-By-Month FX & $\checkmark$ & $\checkmark$ & $\checkmark$ & $\checkmark$ \\
\hline Region-By-Month FX & $\checkmark$ & $\checkmark$ & $\checkmark$ & $\checkmark$ \\
\hline Municipality Size-By-Month FX & $\checkmark$ & $\checkmark$ & $\checkmark$ & $\checkmark$ \\
\hline Observations & $2,790,780$ & $2,790,780$ & $2,790,780$ & $2,790,780$ \\
\hline R-squared & 0.996 & 0.996 & 0.996 & 0.996 \\
\hline Number of Barcode-By-Store Cells & 123,937 & 123,937 & 123,937 & 123,937 \\
\hline Number of Product-By-Store Type-By-Month Cells & 33,516 & 33,516 & 33,516 & 33,516 \\
\hline Number of Region-By-Month Cells & 705 & 705 & 705 & 705 \\
\hline Number of Municipality Size-By-Month Cells & 705 & 705 & 705 & 705 \\
\hline Number of Municipality Clusters & 76 & 76 & 76 & 76 \\
\hline
\end{tabular}

Notes: Table reports regressions of log prices at domestic stores on an indicator for foreign entry interacted with indicators for product groups and store types. The data come from the Mexican CPI price microdata over the period 2002-2014 covering 120 retail product groups and 76 urban municipalities, with a sampling probability designed to reflect nationally representative urban consumption weights. The basic specification is the same as that reported in column 2 of Table 2 except that the foreign entry effect is averaged across quarters and the estimation sample excludes an adjustment period of 24 months after entry. Columns 2-4 interact foreign entry with indicators for different groups of product and store types. Standard errors are clustered at the municipality level and reported in parentheses. ${ }^{*} 10 \%$, $* * 5 \%, * * * 1 \%$ significance levels. 
Table 4: Post-Entry Price Differences for Identical Barcodes

\begin{tabular}{|c|c|c|c|c|}
\hline Dependent Variable: & $\begin{array}{c}(1) \\
\text { Log Price }\end{array}$ & $\begin{array}{c}(2) \\
\text { Log Price } \\
\end{array}$ & $\begin{array}{c}(3) \\
\text { Log Price } \\
\end{array}$ & $\begin{array}{c}(4) \\
\text { Log Price } \\
\end{array}$ \\
\hline Domestic Store & $\begin{array}{l}0.118 * * * \\
(0.00913)\end{array}$ & & & \\
\hline Domestic Store X Food & & $\begin{array}{l}0.124 * * * \\
(0.00979)\end{array}$ & & \\
\hline Domestic Store X Non-Food & & $\begin{array}{c}0.0744 * * * \\
(0.00765)\end{array}$ & & \\
\hline Domestic Store X Traditional & & & $\begin{array}{l}0.173 * * * \\
(0.00874)\end{array}$ & \\
\hline Domestic Store X Modern & & & $\begin{array}{c}0.0397 * * * \\
(0.0113)\end{array}$ & \\
\hline Domestic Store X Food X Traditional & & & & $\begin{array}{l}0.174 * * * \\
(0.00942)\end{array}$ \\
\hline Domestic Store X Non-Food X Traditional & & & & $\begin{array}{c}0.170^{* * *} \\
(0.0108)\end{array}$ \\
\hline Domestic Store X Food X Modern & & & & $\begin{array}{c}0.0431^{* * *} \\
(0.0124)\end{array}$ \\
\hline Domestic Store X Non-Food X Modern & & & & $\begin{array}{c}0.0189 * * * \\
(0.00713)\end{array}$ \\
\hline Municipality-By-Barcode-By-Month FX & $\checkmark$ & $\checkmark$ & $\checkmark$ & $\checkmark$ \\
\hline Observations & $18,659,777$ & $18,659,777$ & $18,659,777$ & $18,659,777$ \\
\hline R-squared & 0.923 & 0.923 & 0.923 & 0.923 \\
\hline Number of Municipalities & 151 & 151 & 151 & 151 \\
\hline
\end{tabular}

Notes: Table reports regressions of log prices at both domestic and foreign stores on an indicator for whether the price is recorded at a foreign store. The data come from the Mexican consumer panel microdata over the period 2011-14. The dependent variable is $\log$ barcode prices, and the reference category in all columns are barcode prices in foreign owned retailers. Columns 2-4 report price differences across different product groups and store types as indicated. Regressions are weighed by household survey weights. Standard errors are clustered at the municipality level and reported in parentheses. ${ }^{*} 10 \%,{ }^{* *} 5 \%,{ }^{* * *} 1 \%$ significance levels.

Table 5: Store Exit

\begin{tabular}{|c|c|c|c|c|c|c|c|c|}
\hline Panel A: Unweighted regressions & \multicolumn{4}{|c|}{$\begin{array}{c}\Delta \log (\text { Number Stores) } 2003-08 \\
\text { Traditional Store Formats }\end{array}$} & \multicolumn{4}{|c|}{$\begin{array}{l}\Delta \log (\text { Number Stores) } 2003-08 \\
\text { Modern Store Formats }\end{array}$} \\
\hline$\Delta$ Foreign Entry 2003-2008 & $\begin{array}{l}-0.019 \\
(0.014)\end{array}$ & $\begin{array}{l}-0.023 \\
(0.014)\end{array}$ & $\begin{array}{l}-0.025^{*} \\
(0.014)\end{array}$ & $\begin{array}{l}-0.024^{*} \\
(0.014)\end{array}$ & $\begin{array}{l}0.0088 \\
(0.067)\end{array}$ & $\begin{array}{l}-0.0065 \\
(0.068)\end{array}$ & $\begin{array}{c}-0.036 \\
(0.069)\end{array}$ & $\begin{array}{l}-0.035 \\
(0.069)\end{array}$ \\
\hline Foreign Entry Pre 2003 & $\begin{array}{c}-0.055^{* * *} \\
(0.013)\end{array}$ & $\begin{array}{c}-0.057 * * * \\
(0.015)\end{array}$ & $\begin{array}{c}-0.035^{* *} \\
(0.015)\end{array}$ & $\begin{array}{c}-0.032^{* *} \\
(0.016)\end{array}$ & $\begin{array}{l}0.20^{* * *} \\
(0.053)\end{array}$ & $\begin{array}{l}0.16^{* * *} \\
(0.058)\end{array}$ & $\begin{array}{l}0.17 * * * \\
(0.060)\end{array}$ & $\begin{array}{r}0.17 * * * \\
(0.062)\end{array}$ \\
\hline$\Delta \log ($ Public Expenditures $)$ & & & $\begin{array}{l}0.12 * * * \\
(0.028)\end{array}$ & $\begin{array}{l}0.12^{* * *} \\
(0.028)\end{array}$ & & & $\begin{array}{c}0.37^{* * * *} \\
(0.12)\end{array}$ & $\begin{array}{c}0.38 * * * \\
(0.12)\end{array}$ \\
\hline$\Delta \log ($ GDP per Capita) & & & & $\begin{array}{l}-0.020 \\
(0.014)\end{array}$ & & & & $\begin{array}{l}-0.012 \\
(0.066)\end{array}$ \\
\hline Geographical Region FX & $x$ & $\checkmark$ & $\checkmark$ & $\checkmark$ & $x$ & $\checkmark$ & $\checkmark$ & $\checkmark$ \\
\hline Municipality Size FX & $x$ & $\checkmark$ & $\checkmark$ & $\checkmark$ & $x$ & $\checkmark$ & $\checkmark$ & $\checkmark$ \\
\hline Observations & 608 & 608 & 564 & 564 & 608 & 608 & 564 & 564 \\
\hline R-squared & 0.022 & 0.056 & 0.107 & 0.110 & 0.015 & 0.085 & 0.107 & 0.107 \\
\hline Median Stores/Municipality & 2088 & 2088 & 2088 & 2088 & 33.5 & 33.5 & 33.5 & 33.5 \\
\hline Panel B: Pop. Weighted regressions & \multicolumn{4}{|c|}{$\begin{array}{c}\Delta \log (\text { Number Stores) } 2003-08 \\
\text { Traditional Store Formats }\end{array}$} & \multicolumn{4}{|c|}{$\begin{array}{c}\Delta \log (\text { Number Stores) } 2003-08 \\
\text { Modern Store Formats }\end{array}$} \\
\hline$\Delta$ Foreign Entry 2003-2008 & $\begin{array}{l}-0.025 \\
(0.022)\end{array}$ & $\begin{array}{l}-0.026 \\
(0.022)\end{array}$ & $\begin{array}{c}-0.039^{* *} \\
(0.018)\end{array}$ & $\begin{array}{c}-0.039^{* *} \\
(0.018)\end{array}$ & $\begin{array}{c}0.022 \\
(0.074)\end{array}$ & $\begin{array}{l}0.0039 \\
(0.076)\end{array}$ & $\begin{array}{l}-0.041 \\
(0.074)\end{array}$ & $\begin{array}{l}-0.039 \\
(0.075)\end{array}$ \\
\hline Foreign Entry Pre 2003 & $\begin{array}{c}-0.091 * * * \\
(0.018)\end{array}$ & $\begin{array}{c}-0.086^{* * *} \\
(0.019)\end{array}$ & $\begin{array}{l}-0.050^{* * *} \\
(0.018)\end{array}$ & $\begin{array}{l}-0.051^{* * *} \\
(0.019)\end{array}$ & $\begin{array}{l}0.13^{* *} \\
(0.060)\end{array}$ & $\begin{array}{c}0.11^{*} \\
(0.063)\end{array}$ & $\begin{array}{l}0.12^{*} \\
(0.070)\end{array}$ & $\begin{array}{c}0.12^{*} \\
(0.069)\end{array}$ \\
\hline$\Delta \log ($ Public Expenditures $)$ & & & $\begin{array}{l}0.14^{* * *} \\
(0.035)\end{array}$ & $\begin{array}{c}0.14 * * * \\
(0.035)\end{array}$ & & & $\begin{array}{c}0.17 \\
(0.14)\end{array}$ & $\begin{array}{c}0.17 \\
(0.14)\end{array}$ \\
\hline$\Delta \log ($ GDP per Capita) & & & & $\begin{array}{l}0.0083 \\
(0.025)\end{array}$ & & & & $\begin{array}{c}-0.048 \\
(0.081)\end{array}$ \\
\hline Geographical Region FX & $x$ & $\checkmark$ & $\checkmark$ & $\checkmark$ & $x$ & $\checkmark$ & $\checkmark$ & $\checkmark$ \\
\hline Municipality Size FX & $x$ & $\checkmark$ & $\checkmark$ & $\checkmark$ & $x$ & $\checkmark$ & $\checkmark$ & $\checkmark$ \\
\hline Observations & 608 & 608 & 564 & 564 & 608 & 608 & 564 & 564 \\
\hline R-squared & 0.086 & 0.117 & 0.157 & 0.158 & 0.016 & 0.180 & 0.162 & 0.163 \\
\hline Median Stores/Municipality & 2088 & 2088 & 2088 & 2088 & 33.5 & 33.5 & 33.5 & 33.5 \\
\hline
\end{tabular}

Notes: Table reports regressions of changes in log store counts between 2003 and 2008 on whether a foreign store first entered over that time period. The data come from the microdata of the Mexican retail census for the years 2003 and 2008 covering 608 urban municipalities. The dependent variable is the change in log municipality-level retail establishments between 2003 and 2008 . Columns 1-4 and 9-12 report results for the traditional domestic retail segment, and columns 5-8 and 13-16 report results for the modern domestic retail segment. The upper panel is unweighted and the lower panel weights using municipality employment counts from the 2003 Economic Census. Standard errors are clustered at the state level. $* 10 \%, * * 5 \%, * * 1 \%$ significance levels. 
Table 6: Effect on Incomes - Heterogeneity

\begin{tabular}{|c|c|c|c|c|c|c|}
\hline Dependent Variable: & $\begin{array}{c}(1) \\
\text { Log (Monthly } \\
\text { Income) } \\
\end{array}$ & $\begin{array}{c}(2) \\
\text { Log (Monthly } \\
\text { Income) } \\
\end{array}$ & $\begin{array}{c}\text { (3) } \\
\text { Log (Monthly } \\
\text { Income) } \\
\end{array}$ & $\begin{array}{c}(4) \\
\text { Log } \\
\text { (Employment) } \\
\end{array}$ & $\begin{array}{c}\text { (5) } \\
\text { Log } \\
\text { (Employment) } \\
\end{array}$ & $\begin{array}{c}(6) \\
\text { Log } \\
\text { (Employment) } \\
\end{array}$ \\
\hline Foreign Entry X Modern Retail Workers & $\begin{array}{c}-0.000278 \\
(0.0192)\end{array}$ & $\begin{array}{l}-0.0348^{*} \\
(0.0204)\end{array}$ & $\begin{array}{l}-0.0278 \\
(0.0212)\end{array}$ & $\begin{array}{l}-0.00396 \\
(0.0653)\end{array}$ & $\begin{array}{c}0.0369 \\
(0.0714)\end{array}$ & $\begin{array}{c}0.0392 \\
(0.0561)\end{array}$ \\
\hline Foreign Entry X Traditional Retail Workers & $\begin{array}{c}-0.0356^{*} \\
(0.0199)\end{array}$ & $\begin{array}{c}-0.0571 * * * \\
(0.0216)\end{array}$ & $\begin{array}{c}-0.0592 * * \\
(0.0240)\end{array}$ & $\begin{array}{l}-0.104 * \\
(0.0531)\end{array}$ & $\begin{array}{l}-0.0942 \\
(0.0571)\end{array}$ & $\begin{array}{l}-0.113 * * \\
(0.0552)\end{array}$ \\
\hline Foreign Entry X Agriculture & $\begin{array}{c}0.0265 \\
(0.0264)\end{array}$ & $\begin{array}{c}0.0218 \\
(0.0311)\end{array}$ & $\begin{array}{c}0.0202 \\
(0.0307)\end{array}$ & $\begin{array}{l}-0.0597 \\
(0.0809)\end{array}$ & $\begin{array}{r}-0.0285 \\
(0.101)\end{array}$ & $\begin{array}{c}-0.00811 \\
(0.106)\end{array}$ \\
\hline Foreign Entry X Manufacturing & $\begin{array}{l}-0.00513 \\
(0.0174)\end{array}$ & $\begin{array}{l}-0.00612 \\
(0.0186)\end{array}$ & $\begin{array}{c}0.0117 \\
(0.0187) \\
\end{array}$ & $\begin{array}{c}-0.166 * * * \\
(0.0379)\end{array}$ & $\begin{array}{l}0.00572 \\
(0.0368)\end{array}$ & $\begin{array}{l}-0.0166 \\
(0.0380) \\
\end{array}$ \\
\hline Person Controls & $\checkmark$ & $\checkmark$ & $\checkmark$ & $x$ & $x$ & $x$ \\
\hline Municipality-by-Quarter FX & $\checkmark$ & $\checkmark$ & $\checkmark$ & $\checkmark$ & $\checkmark$ & $\checkmark$ \\
\hline Municipality-by-Group Fixed Effects & $\checkmark$ & $\checkmark$ & $\checkmark$ & $\checkmark$ & $\checkmark$ & $\checkmark$ \\
\hline Group-by-Quarter FX & $x$ & $\checkmark$ & $\checkmark$ & $x$ & $\checkmark$ & $\checkmark$ \\
\hline State-by-Group Time Trends & $x$ & $x$ & $\checkmark$ & $x$ & $x$ & $\checkmark$ \\
\hline Observations & $3,878,561$ & $3,878,561$ & $3,878,561$ & 47,666 & 47,666 & 47,666 \\
\hline R-squared & 0.340 & 0.340 & 0.341 & 0.963 & 0.965 & 0.967 \\
\hline Number of Individuals & $1,455,911$ & $1,455,911$ & $1,455,911$ & $1,455,911$ & $1,455,911$ & $1,455,911$ \\
\hline Number of Municipality-by-Quarter Cells & 8,574 & 8,574 & 8,574 & 8,574 & 8,574 & 8,574 \\
\hline Number of State-by-Group Time Trends & 160 & 160 & 160 & 160 & 160 & 160 \\
\hline Number of Municipality Clusters & 273 & 273 & 273 & 273 & 273 & 273 \\
\hline
\end{tabular}

Notes: Table reports regressions of log incomes and log number of employees on an indicator for foreign entry interacted with sectoral dummies. Data come from the 273 urban municipalities in the employment and occupation surveys over the period 2002-2012. The dependent variable in Columns 1-3 is individual log monthly incomes. Dependent variable in columns 4-6 is the log number of employed individuals by sector. The regressions include different combinations of fixed effects and controls as indicated in the table. Columns 1-3 weight regressions by household survey weights, whereas Columns 4-6 use the survey weights to compute the sum of employment by sector and then weight the regressions by the sum of household survey weights at the municipality-level. Standard errors are clustered at the municipality level and reported in parentheses. ${ }^{*} 10 \%,{ }^{* *} 5 \%, * * * 1 \%$ significance levels.

Table 7: Effect on Store Profits

\begin{tabular}{|c|c|c|c|c|c|c|c|c|}
\hline \multirow[t]{3}{*}{ Dependent Variable: } & \multicolumn{8}{|c|}{$\Delta \log ($ Mean Profit) 2003-08 } \\
\hline & (1) & (2) & (3) & (4) & (5) & (6) & (7) & (8) \\
\hline & \multicolumn{4}{|c|}{ Unweighted regressions } & \multicolumn{4}{|c|}{ Population weighted regressions } \\
\hline \multirow[t]{2}{*}{$\Delta$ Foreign Entry 2003-2008 } & $-0.049 *$ & -0.047 & -0.048 & $-0.051 *$ & -0.039 & -0.041 & -0.043 & -0.044 \\
\hline & $(0.028)$ & $(0.029)$ & $(0.030)$ & $(0.030)$ & $(0.032)$ & $(0.033)$ & $(0.034)$ & $(0.034)$ \\
\hline \multirow[t]{2}{*}{ Foreign Entry Pre 2003} & $-0.087 * * *$ & $-0.082 * * *$ & $-0.071 * * *$ & $-0.081 * * *$ & $-0.070 * *$ & $-0.074 * *$ & -0.043 & -0.047 \\
\hline & $(0.024)$ & $(0.024)$ & $(0.026)$ & $(0.027)$ & $(0.031)$ & $(0.032)$ & $(0.032)$ & $(0.034)$ \\
\hline \multirow[t]{2}{*}{$\Delta \log$ (Public Expenditures) } & & & 0.042 & 0.038 & & & $0.079 *$ & $0.075 *$ \\
\hline & & & $(0.046)$ & $(0.045)$ & & & $(0.044)$ & (0.045) \\
\hline \multirow[t]{2}{*}{$\Delta \log ($ GDP per Capita) } & & & & $0.061^{*}$ & & & & 0.034 \\
\hline & & & & $(0.035)$ & & & & $(0.030)$ \\
\hline Geographical Region FX & $x$ & $\checkmark$ & $\checkmark$ & $\checkmark$ & $x$ & $\checkmark$ & $\checkmark$ & $\checkmark$ \\
\hline Municipality Size FX & $x$ & $\checkmark$ & $\checkmark$ & $\checkmark$ & $x$ & $\checkmark$ & $\checkmark$ & $\checkmark$ \\
\hline Observations & 608 & 608 & 564 & 564 & 608 & 608 & 564 & 564 \\
\hline R-squared & 0.014 & 0.061 & 0.064 & 0.071 & 0.020 & 0.071 & 0.112 & 0.115 \\
\hline $\begin{array}{l}\text { Median Number of Stores Per } \\
\text { Municipality in } 2003 \text { and } 2008\end{array}$ & 2088 & 2088 & 2088 & 2088 & 2088 & 2088 & 2088 & 2088 \\
\hline
\end{tabular}

Notes: Table reports regressions of changes in log profits between 2003 and 2008 on whether a foreign store first entered over that time period. The data come from the microdata of the Mexican retail census for the years 2003 and 2008 covering 608 urban municipalities. The dependent variable is the change in log mean municipality profits between 2003 and 2008 among traditional retail establishments. Columns 1-4 are unweighted and columns 5-8 weight using municipality employment counts from the 2003 Economic Census. Standard errors are clustered at the state level. ${ }^{*} 10 \%, * * 5 \%, * * 1 \%$ significance levels. 


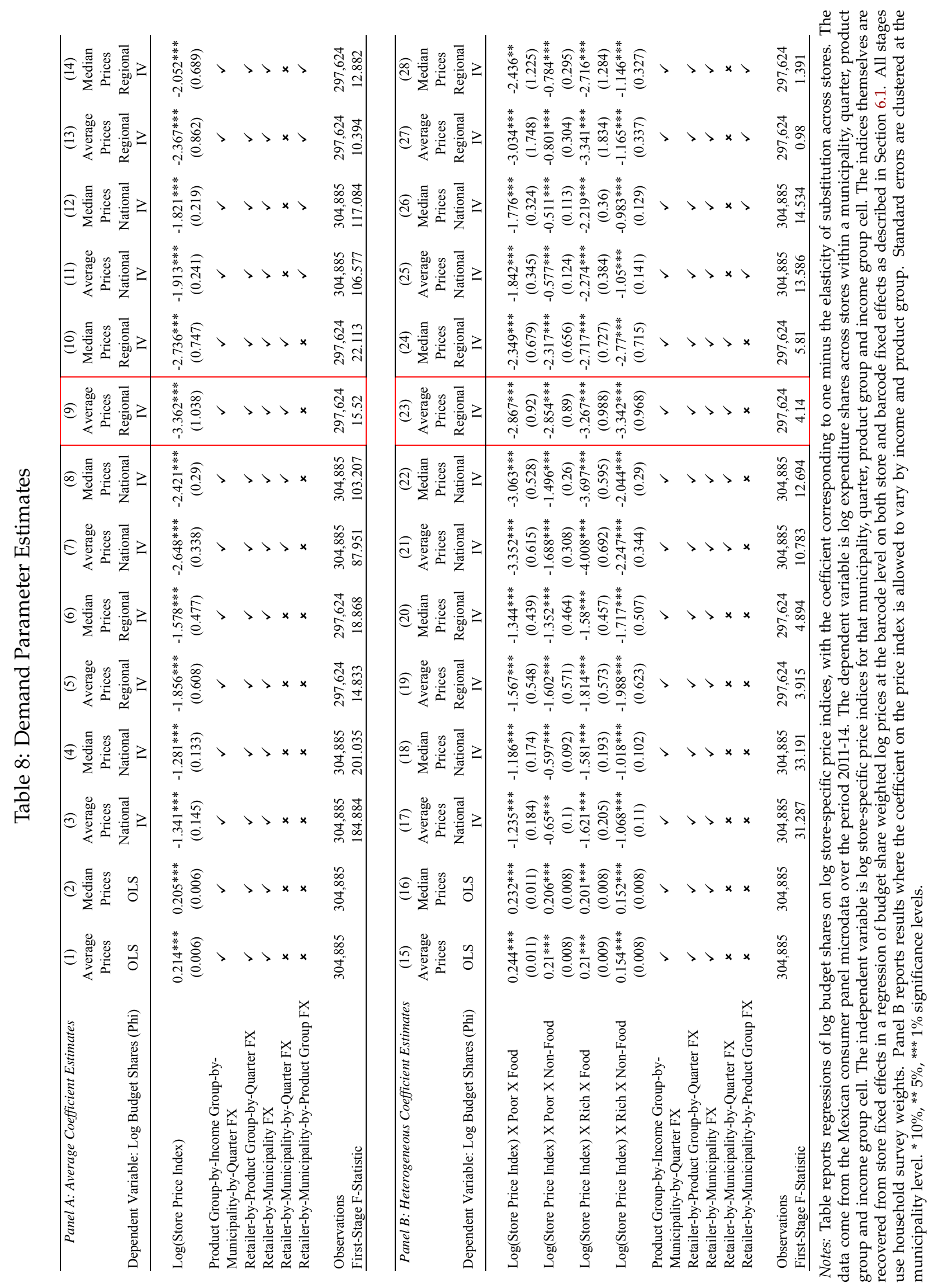


Table 9: Household Welfare Effect - Decomposition

\begin{tabular}{|c|c|c|c|c|c|c|c|}
\hline \multirow[b]{3}{*}{ Dependent Variable: } & (1) & (2) & (3) & (4) & (5) & (6) & (7) \\
\hline & \multicolumn{7}{|c|}{ Exact Under CES Approach } \\
\hline & Total Effect & $\begin{array}{l}\text { Direct Price } \\
\text { Index Effect }\end{array}$ & $\begin{array}{c}\text { Pro-Competitive } \\
\text { Price Effect }\end{array}$ & $\begin{array}{c}\text { Pro-Competitive } \\
\text { Exit Effect }\end{array}$ & $\begin{array}{l}\text { Retail Labor } \\
\text { Income Effect }\end{array}$ & $\begin{array}{c}\text { Retail Profit } \\
\text { Effect }\end{array}$ & $\begin{array}{c}\text { Other Income } \\
\text { Effect }\end{array}$ \\
\hline Average Effect & $\begin{array}{c}0.0601 * * * \\
(0.0104)\end{array}$ & $\begin{array}{c}0.0551 * * * \\
(0.0006)\end{array}$ & $\begin{array}{c}0.0158^{* * *} \\
(0.0050)\end{array}$ & $\begin{array}{l}-0.00705 \\
(0.0053)\end{array}$ & $\begin{array}{c}-0.00397 * * \\
(0.0020)\end{array}$ & $\begin{array}{c}-0.00269^{* *} \\
(0.0013)\end{array}$ & $\begin{array}{l}0.00289 \\
(0.0078)\end{array}$ \\
\hline Max & 0.730 & 0.177 & 0.055 & 0.000 & 0.692 & 0.000 & 0.020 \\
\hline Min & -0.986 & 0.000 & 0.000 & -0.014 & -1.000 & -1.000 & -1.000 \\
\hline Proportion Negative & 0.024 & 0.000 & 0.000 & 0.999 & 0.074 & 0.058 & 0.004 \\
\hline Observations (Households) & 12,293 & 12,293 & 12,293 & 12,293 & 12,293 & 12,293 & 12,293 \\
\hline \multirow[t]{2}{*}{ Number of Municipality Clusters } & 240 & 240 & 240 & 240 & 240 & 240 & 240 \\
\hline & $(8)$ & (9) & $(10)$ & $(11)$ & (12) & (13) & (14) \\
\hline Dependent Variable: & Total Effect & $\begin{array}{l}\text { Direct Price } \\
\text { Index Effect }\end{array}$ & $\begin{array}{c}\mathrm{F} \\
\text { Pro-Competitive } \\
\text { Price Effect }\end{array}$ & $\begin{array}{l}\text { irst Order Approac } \\
\text { Pro-Competitive } \\
\text { Exit Effect }\end{array}$ & $\begin{array}{l}\text { Retail Labor } \\
\text { Income Effect }\end{array}$ & $\begin{array}{c}\text { Retail Profit } \\
\text { Effect }\end{array}$ & $\begin{array}{c}\text { Other Income } \\
\text { Effect }\end{array}$ \\
\hline Average Effect & $\begin{array}{c}0.0275^{* * *} \\
(0.0093)\end{array}$ & $\begin{array}{c}0.0204 * * * \\
(0.0014)\end{array}$ & $\begin{array}{c}0.0109 * * * \\
(0.0037)\end{array}$ & $\begin{array}{c}0 \\
(0.0000)\end{array}$ & $\begin{array}{c}-0.00397 * * \\
(0.0020)\end{array}$ & $\begin{array}{c}-0.00269^{* *} \\
(0.0013)\end{array}$ & $\begin{array}{l}0.00289 \\
(0.0078)\end{array}$ \\
\hline Max & 0.715 & 0.060 & 0.031 & 0.000 & 0.692 & 0.000 & 0.020 \\
\hline Min & -0.995 & 0.000 & 0.000 & 0.000 & -1.000 & -1.000 & -1.000 \\
\hline Proportion Negative & 0.057 & 0.000 & 0.000 & 0.000 & 0.074 & 0.058 & 0.004 \\
\hline Observations (Households) & 12,293 & 12,293 & 12,293 & 12,293 & 12,293 & 12,293 & 12,293 \\
\hline Number of Municipality Clusters & 240 & 240 & 240 & 240 & 240 & 240 & 240 \\
\hline
\end{tabular}

Table 10: Effect on Average Household Welfare - Robustness

\begin{tabular}{|c|c|c|c|c|c|c|c|c|c|c|}
\hline $\boldsymbol{\eta}=\left[\begin{array}{l}\eta_{\text {poor }, \text { food }} \\
\eta_{\text {rich food }}\end{array}\right.$ & $\left.\begin{array}{c}\eta_{\text {poor,nonfood }} \\
\eta_{\text {rich,nonfood }}\end{array}\right]=\left[\begin{array}{ll}3.87 & 3.85 \\
4.27 & 4.34\end{array}\right]$ & $\boldsymbol{\eta}-2$ & $\eta-1.5$ & $\boldsymbol{\eta}-1$ & $\eta-0.5$ & $\eta$ & $\boldsymbol{\eta}+0.5$ & $\boldsymbol{\eta}+1$ & $\boldsymbol{\eta}+1.5$ & $\eta+2$ \\
\hline \multicolumn{2}{|c|}{$\begin{array}{l}0 \text { Percent of Pro-Competitive Effect } \\
\text { for Non-Barcoded Products }\end{array}$} & 0.1355 & 0.0964 & 0.0716 & 0.0626 & 0.0520 & 0.0468 & 0.0394 & 0.0374 & 0.0329 \\
\hline \multicolumn{2}{|c|}{$\begin{array}{l}50 \text { Percent of Pro-Competitive Effect } \\
\text { for Non-Barcoded Products }\end{array}$} & 0.1392 & 0.0986 & 0.0785 & 0.0649 & 0.0554 & 0.0485 & 0.0453 & 0.0389 & 0.0388 \\
\hline \multicolumn{2}{|c|}{$\begin{array}{l}100 \text { Percent of Pro-Competitive Effect } \\
\text { for Non-Barcoded Products }\end{array}$} & 0.1423 & 0.1004 & 0.0821 & 0.0667 & 0.0601 & 0.0509 & 0.0470 & 0.0434 & 0.0400 \\
\hline \multicolumn{2}{|c|}{$\begin{array}{l}150 \text { Percent of Pro-Competitive Effect } \\
\text { for Non-Barcoded Products }\end{array}$} & 0.1454 & 0.1063 & 0.0841 & 0.0732 & 0.0640 & 0.0573 & 0.0534 & 0.0492 & 0.0453 \\
\hline \multicolumn{2}{|c|}{$\begin{array}{l}200 \text { Percent of Pro-Competitive Effect } \\
\text { for Non-Barcoded Products }\end{array}$} & 0.1468 & 0.1075 & 0.0889 & 0.0728 & 0.0653 & 0.0605 & 0.0558 & 0.0523 & 0.0490 \\
\hline
\end{tabular}

Notes: Table reports the welfare effects of foreign retail entry from the quantification exercise described in Section 6 but using alternative estimates and assumptions. Each cell is the survey-weighted mean effect across all 12,293 households in the income and expenditure surveys that reside in the 240 urban municipalities that had not yet experienced foreign retail entry at the time of the survey. The highlighted estimate corresponds to the average effect in Table 9 which applies our baseline assumption that the pro-competitive effects on prices in domestic stores that we estimated using barcoded items are identical for non-barcoded items, and that the elasticities are those from column 23 of Table 8 . Other columns vary the value of these elasticities by adding or subtracting to the set of four elasticities in column 23 of Table 8 in increments of 0.5 . Other rows vary the relative strength of the pro-competitive effects on non-barcoded retail items. 


\section{Online Appendix - Not for Publication}

\section{A Additional Figures and Tables}

Figure A.1: Foreign Retail Market Shares Post Entry: Restricted Estimation Sample
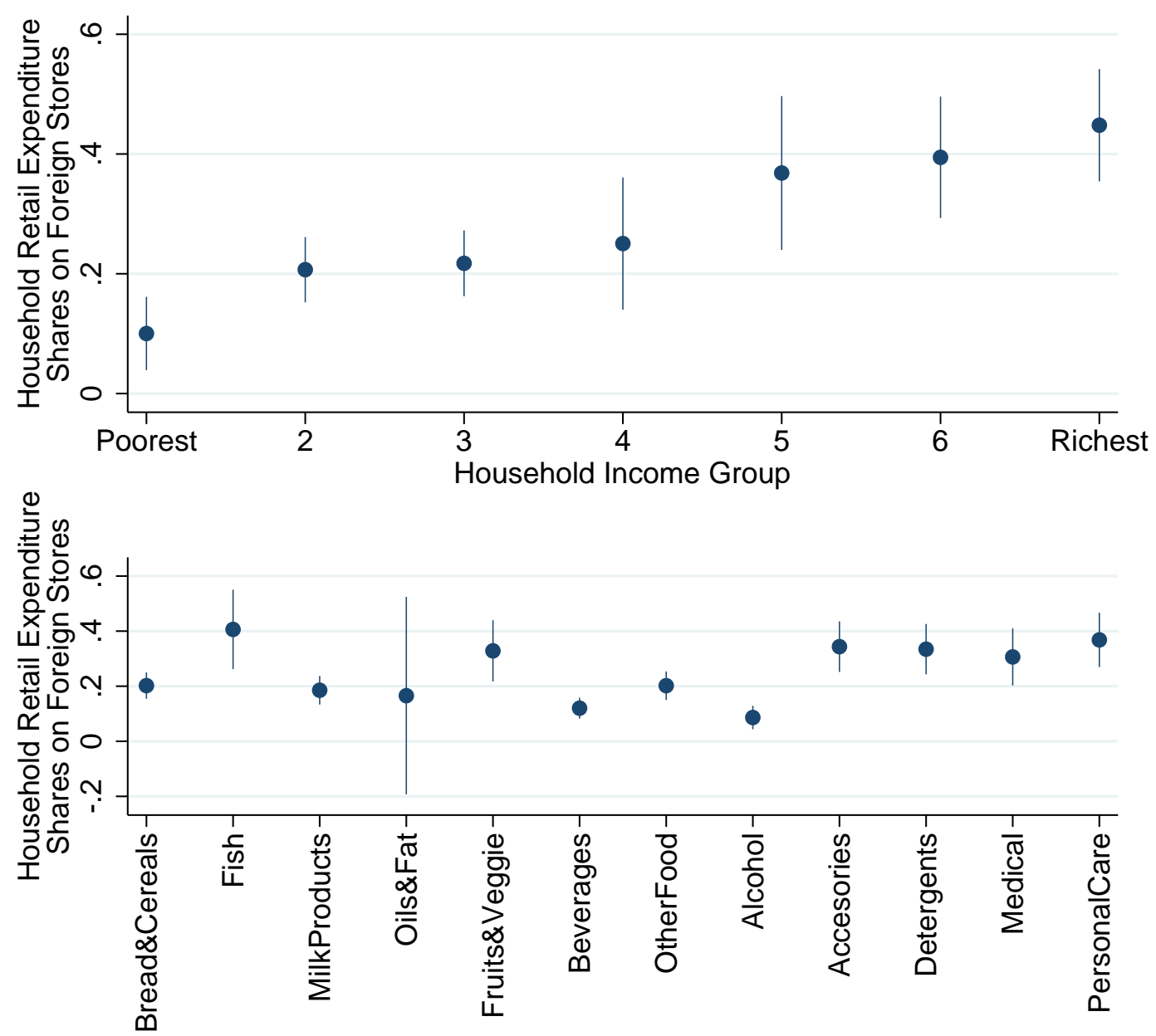

Notes: The graphs plot the share of household retail expenditure spent at foreign stores. The data come from the Mexican consumer panel microdata for the years 2011-14. We restrict attention to municipalities where the first foreign store entered between two and three years previously. Expenditure shares are weighted by household survey weights. Both graphs depict $95 \%$ confidence intervals based on standard errors clustered at the municipality level. 
Figure A.2: Foreign Retail Market Shares Post Entry: Municipality-by-Quarter Fixed Effects

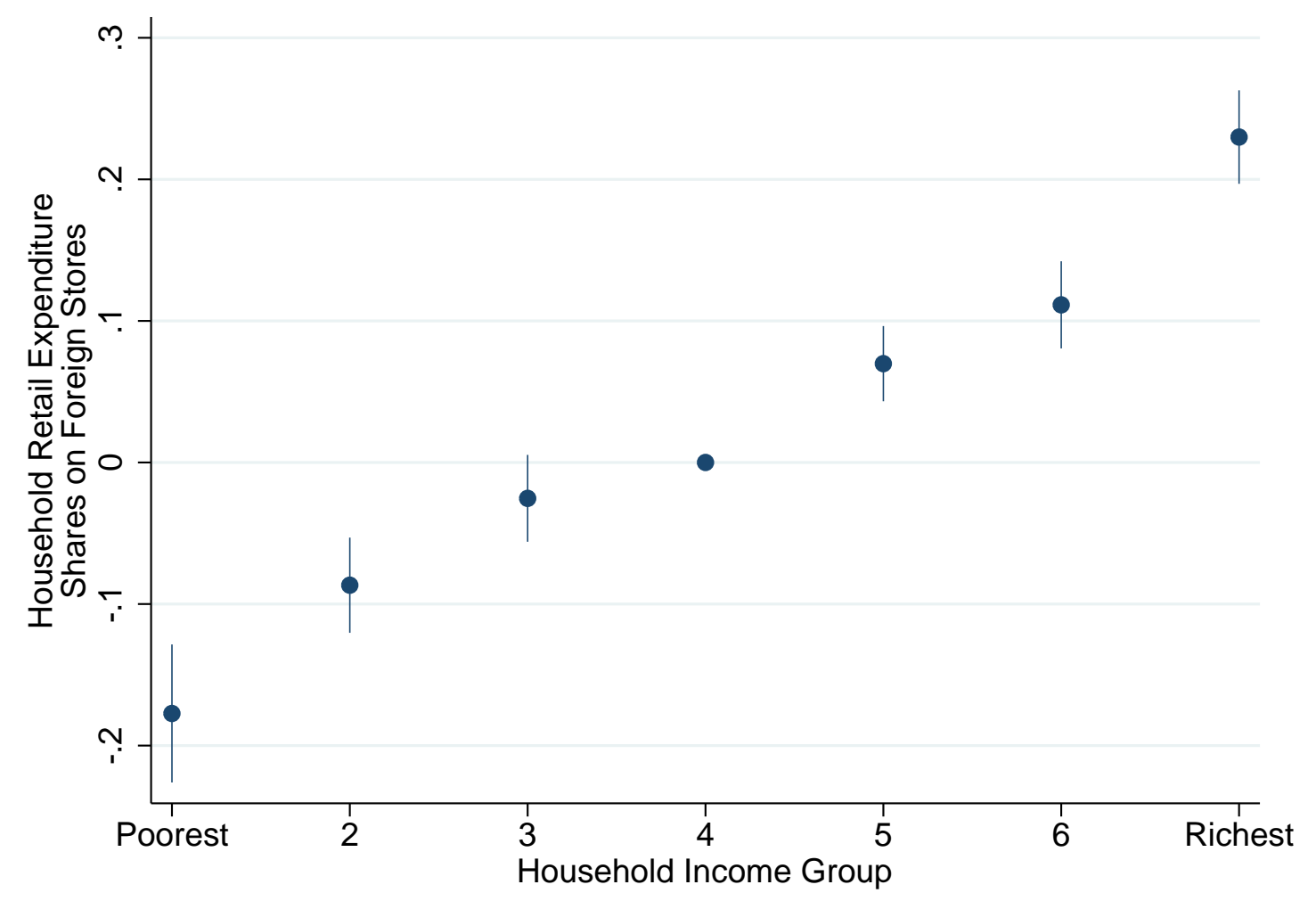

Notes: The graphs plot the share of household retail expenditure spent at foreign stores. The data come from the Mexican consumer panel microdata for the years 2011-14. We restrict attention to municipalities where the first foreign store entered more than two years previously. Municipality-by-quarter fixed effects included in the estimation of these shares. The omitted income group is the median income group. Regressions are weighted by household survey weights. Expenditure shares are weighted by household survey weights. Both graphs depict $95 \%$ confidence intervals based on standard errors clustered at the municipality level. 
Figure A.3: Gains from Foreign Retail Entry across the Income Distribution: First Order Approach

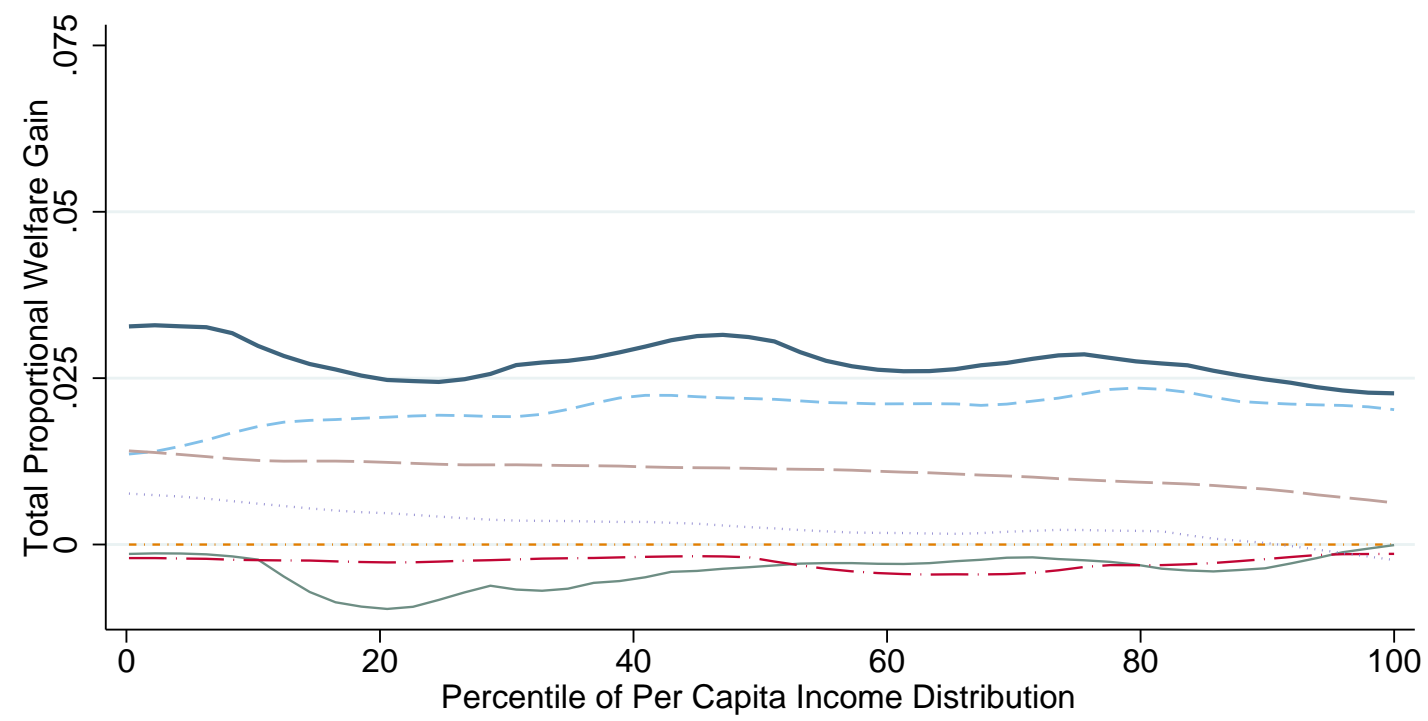

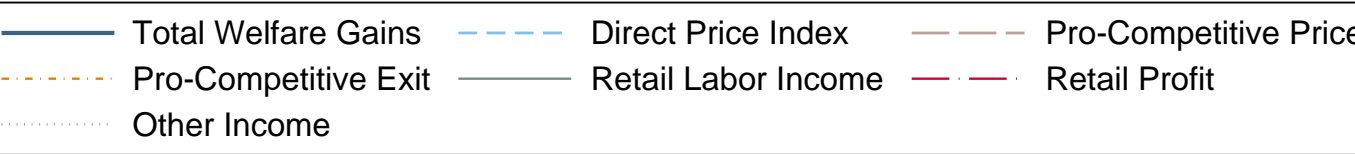

Notes: The graph contains non-parametric plots of the household gains from foreign retail entry against the pre-entry location in the income distribution. Gains calculated from the quantification exercise described in Section 6 using the first-order approach. Pre-entry incomes as well as household-level income and expenditure shares come from the 12,293 households in the income and expenditure surveys that reside in the 240 urban municipalities that had not yet experienced foreign retail entry at the time of the survey. The figure decomposes the total gains into its constituent parts. Plots are weighted by household survey weights. 


\section{Table A.1: Effect on Product Replacements and Basket Expansions Among Domestic Retailers}

\begin{tabular}{|c|c|c|c|c|c|c|}
\hline & (1) & (2) & (3) & (4) & (5) & (6) \\
\hline Dependent Variable: & Product Replacement & Product Replacement & Product Replacement & Basket Expansion & Basket Expansion & Basket Expansion \\
\hline Foreign Entry Dummy & $\begin{array}{c}-0.000501 \\
(0.00323)\end{array}$ & $\begin{array}{c}-0.000446 \\
(0.00451)\end{array}$ & $\begin{array}{l}-5.47 \mathrm{e}-05 \\
(0.00474)\end{array}$ & $\begin{array}{c}0.00110 \\
(0.00155)\end{array}$ & $\begin{array}{c}0.00165 \\
(0.00218)\end{array}$ & $\begin{array}{c}0.00214 \\
(0.00228)\end{array}$ \\
\hline Month FX & $\checkmark$ & $\checkmark$ & $\checkmark$ & $\checkmark$ & $\checkmark$ & $\checkmark$ \\
\hline Barcode-By-Store FX & $\checkmark$ & $\checkmark$ & $\checkmark$ & $x$ & $x$ & $x$ \\
\hline CPI Reporting Line FX & $x$ & $x$ & $x$ & $\checkmark$ & $\checkmark$ & $\checkmark$ \\
\hline Product Group-By-Store Type-By-Month FX & $x$ & $\checkmark$ & $\checkmark$ & $x$ & $\checkmark$ & $\checkmark$ \\
\hline Region-By-Month FX & $x$ & $\checkmark$ & $\checkmark$ & $x$ & $\checkmark$ & $\checkmark$ \\
\hline Municipality Size-By-Month FX & $\mathbf{x}$ & $\checkmark$ & $\checkmark$ & $\mathbf{x}$ & $\checkmark$ & $\checkmark$ \\
\hline Control for Local Government Expenditure & $x$ & $x$ & $\checkmark$ & $x$ & $x$ & $\checkmark$ \\
\hline Observations & $3,228,544$ & $2,850,238$ & $2,560,558$ & $3,553,689$ & $3,230,077$ & $2,900,305$ \\
\hline R-squared & 0.141 & 0.160 & 0.161 & 0.027 & 0.143 & 0.150 \\
\hline
\end{tabular}

Notes: Table reports the regression of an indicator for product availability in the CPI surveys on a foreign entry dummy. The dependent variable in columns 1-3 is product replacement events $(0,1)$ (i.e. when a product item is replaced within an existing reporting line in the CPI data), or basket expansion events $(0,1)$ in columns 3-6 (i.e. when the enumerator adds an additional product reporting line in the data). The replacement variable has values of zero until the month when the product was replaced. The expansion variable takes values of 1 in the first period the reporting line was added and zeroes thereafter. The various fixed effects are as described in the main text, except for the basket expansion regressions, where we take reporting line fixed effects instead of barcode-by-store fixed effects. Standard errors are clustered at the municipality level and reported in parentheses. ${ }^{*} 10 \%, * * 5 \%, * * * 1 \%$ significance levels. 


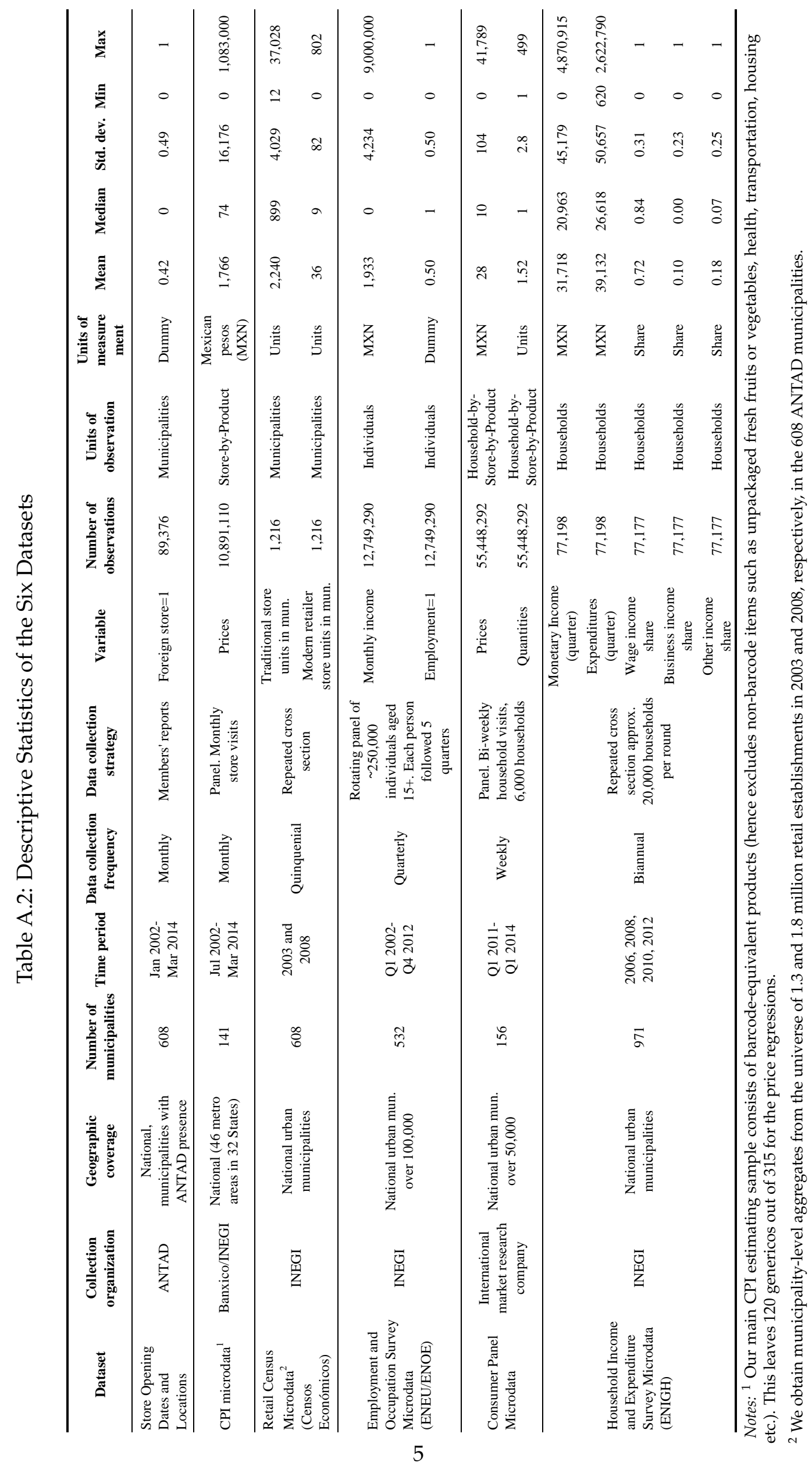


Table A.3: Pro-Competitive Effect With Alternative Weights

\begin{tabular}{|c|c|c|c|c|c|c|c|c|}
\hline $\begin{array}{l}\text { Dependent Variable: } \\
\text { Specification: }\end{array}$ & $\begin{array}{c}(1) \\
\text { Log Price } \\
\text { Baseline } \\
\end{array}$ & $\begin{array}{c}(2) \\
\text { Log Price } \\
\text { Alternative Weights }\end{array}$ & $\begin{array}{c}\text { (3) } \\
\text { Log Price } \\
\text { Baseline }\end{array}$ & $\begin{array}{c}(4) \\
\text { Log Price } \\
\text { Alternative Weights }\end{array}$ & $\begin{array}{c}5) \\
\text { Log Price } \\
\text { Baseline }\end{array}$ & $\begin{array}{c}6) \\
\text { Log Price } \\
\text { Alternative Weights }\end{array}$ & $\begin{array}{c}(7) \\
\text { Log Price } \\
\text { Baseline }\end{array}$ & $\begin{array}{c}(8) \\
\text { Log Price } \\
\text { Alternative Weights }\end{array}$ \\
\hline Foreign Entry & $\begin{array}{c}-0.0373 * * * * \\
(0.0119)\end{array}$ & $\begin{array}{c}-0.0359 * * \\
(0.0171)\end{array}$ & & & & & & \\
\hline Foreign Entry X Food & & & $\begin{array}{c}-0.0395 * * * * \\
(0.0137)\end{array}$ & $\begin{array}{c}-0.0341 * * \\
(0.0150)\end{array}$ & & & & \\
\hline Foreign Entry X Non-Food & & & $\begin{array}{c}-0.0362 * * \\
(0.0154)\end{array}$ & $\begin{array}{l}-0.0366 \\
(0.0226)\end{array}$ & & & & \\
\hline Foreign Entry X Traditional Store & & & & & $\begin{array}{l}-0.0235 \\
(0.0198)\end{array}$ & $\begin{array}{c}-0.0265 \\
(0.0242)\end{array}$ & & \\
\hline Foreign Entry X Modern Store & & & & & $\begin{array}{c}-0.0526 * * * \\
(0.0169)\end{array}$ & $\begin{array}{c}-0.0526^{* * * *} \\
(0.0158)\end{array}$ & & \\
\hline Foreign Entry X Food X Traditional Store & & & & & & & $\begin{array}{r}-0.00425 \\
(0.0162)\end{array}$ & $\begin{array}{c}0.000410 \\
(0.0179)\end{array}$ \\
\hline Foreign Entry X Non-Food X Traditional Store & & & & & & & $\begin{array}{l}-0.0287 \\
(0.0231)\end{array}$ & $\begin{array}{l}-0.0306 \\
(0.0274)\end{array}$ \\
\hline Foreign Entry X Food X Modern Store & & & & & & & $\begin{array}{c}-0.0559^{* * *} \\
(0.0169)\end{array}$ & $\begin{array}{c}-0.0502 * * * \\
(0.0173)\end{array}$ \\
\hline Foreign Entry X Non-Food X Modern Store & & & & & & & $\begin{array}{l}-0.0497^{*} \\
(0.0255) \\
\end{array}$ & $\begin{array}{c}-0.0551^{* *} \\
(0.0265) \\
\end{array}$ \\
\hline Barcode-By-Store FX & $\checkmark$ & $\checkmark$ & $\checkmark$ & $\checkmark$ & $\checkmark$ & $\checkmark$ & $\checkmark$ & $\checkmark$ \\
\hline Product-By-Store Type-By-Month FX & $\checkmark$ & $\checkmark$ & $\checkmark$ & $\checkmark$ & $\checkmark$ & $\checkmark$ & $\checkmark$ & $\checkmark$ \\
\hline Region-By-Month FX & $\checkmark$ & $\checkmark$ & $\checkmark$ & $\checkmark$ & $\checkmark$ & $\checkmark$ & $\checkmark$ & $\checkmark$ \\
\hline Municipality Size-By-Month FX & $\checkmark$ & $\checkmark$ & $\checkmark$ & $\checkmark$ & $\checkmark$ & $\checkmark$ & $\checkmark$ & $\checkmark$ \\
\hline Observations & $2,790,780$ & $2,790,780$ & $2,790,780$ & $2,790,780$ & $2,790,780$ & $2,790,780$ & $2,790,780$ & $2,790,780$ \\
\hline R-squared & 0.996 & 0.998 & 0.996 & 0.998 & 0.996 & 0.998 & 0.996 & 0.998 \\
\hline Number of Barcode-By-Store Cells & 123,937 & 123,937 & 123,937 & 123,937 & 123,937 & 123,937 & 123,937 & 123,937 \\
\hline Number of Product-By-Store Type-By-Month Cells & 33,516 & 33,516 & 33,516 & 33,516 & 33,516 & 33,516 & 33,516 & 33,516 \\
\hline Number of Region-By-Month Cells & 705 & 705 & 705 & 705 & 705 & 705 & 705 & 705 \\
\hline Number of Municipality Size-By-Month Cells & 705 & 705 & 705 & 705 & 705 & 705 & 705 & 705 \\
\hline Number of Municipality Clusters & 76 & 76 & 76 & 76 & 76 & 76 & 76 & 76 \\
\hline
\end{tabular}

Notes: The table reports regressions of log prices at domestic stores on an indicator for foreign entry interacted with indicators for product groups and store types. The data come from the Mexican CPI price microdata over the period 2002-2014 covering 120 retail product groups and 76 urban municipalities, with a sampling probability designed to reflect nationally representative urban consumption weights. The estimation sample excludes an adjustment period of 24 months after entry. Columns with 'Alternative Weights' in header re-weight individual observations (price quotes) so that the product group receives a weight in proportion to the average household budget share from the Mexican household consumption survey (ENIGH) in 2002. Standard errors are clustered at the municipality level and reported in parentheses. ${ }^{*} 10 \%, * * 5 \%, * * * 1 \%$ significance levels. 
Table A.4: Pro-Competitive Price Effect Estimated from Single Store Entry Events

\begin{tabular}{|c|c|c|c|}
\hline & (1) & (2) & (3) \\
\hline Dependent Variable: & Log Price & Log Price & Log Price \\
\hline \multirow[t]{2}{*}{ Foreign Entry - More Than Four Quarters Before (Unbalanced) } & -0.000527 & 0.00352 & 0.000301 \\
\hline & $(0.00508)$ & $(0.00839)$ & $(0.00751)$ \\
\hline \multirow[t]{2}{*}{ Foreign Entry - Four Quarters Before } & 0.00230 & 0.00423 & 0.00113 \\
\hline & $(0.00386)$ & $(0.00577)$ & $(0.00490)$ \\
\hline \multirow[t]{2}{*}{ Foreign Entry - Three Quarters Before } & -0.00262 & -0.00164 & -0.00398 \\
\hline & $(0.00368)$ & $(0.00429)$ & $(0.00396)$ \\
\hline \multirow[t]{2}{*}{ Foreign Entry - Two Quarters Before (Omitted) } & 0 & 0 & 0 \\
\hline & $(0)$ & $(0)$ & $(0)$ \\
\hline \multirow[t]{2}{*}{ Foreign Entry - One Quarter Before } & -0.000799 & -0.00213 & -0.00245 \\
\hline & $(0.00414)$ & $(0.00431)$ & $(0.00434)$ \\
\hline \multirow[t]{2}{*}{ Foreign Entry - One Quarter After } & -0.00813 & -0.00689 & -0.00763 \\
\hline & $(0.00690)$ & $(0.00693)$ & $(0.00706)$ \\
\hline \multirow[t]{2}{*}{ Foreign Entry - Two Quarters After } & $-0.0140 *$ & -0.0118 & -0.0133 \\
\hline & $(0.00741)$ & $(0.00809)$ & $(0.00800)$ \\
\hline \multirow[t]{2}{*}{ Foreign Entry - Three Quarters After } & $-0.0230 *$ & $-0.0215^{*}$ & $-0.0239 *$ \\
\hline & $(0.0122)$ & $(0.0127)$ & $(0.0126)$ \\
\hline \multirow[t]{2}{*}{ Foreign Entry - Four Quarters After } & -0.0208 & -0.0222 & $-0.0247 *$ \\
\hline & $(0.0133)$ & $(0.0135)$ & $(0.0133)$ \\
\hline \multirow[t]{2}{*}{ Foreign Entry - Five Quarters After } & -0.0156 & -0.0161 & -0.0191 \\
\hline & $(0.0161)$ & $(0.0145)$ & $(0.0140)$ \\
\hline \multirow[t]{2}{*}{ Foreign Entry - Six Quarters After } & -0.0214 & -0.0215 & $-0.0239 *$ \\
\hline & $(0.0150)$ & $(0.0144)$ & $(0.0134)$ \\
\hline \multirow[t]{2}{*}{ Foreign Entry - Seven Quarters After } & -0.0206 & -0.0195 & -0.0217 \\
\hline & $(0.0161)$ & $(0.0153)$ & $(0.0141)$ \\
\hline \multirow[t]{2}{*}{ Foreign Entry - Eight Quarters After } & -0.0215 & -0.0228 & $-0.0243^{*}$ \\
\hline & $(0.0162)$ & $(0.0151)$ & $(0.0135)$ \\
\hline \multirow[t]{2}{*}{ Foreign Entry - Nine Quarters After } & $-0.0266^{*}$ & $-0.0271 *$ & $-0.0259 * *$ \\
\hline & $(0.0157)$ & $(0.0144)$ & $(0.0121)$ \\
\hline \multirow[t]{2}{*}{ Foreign Entry - Ten Quarters After } & $-0.0336 * *$ & $-0.0324 * *$ & $-0.0291 * *$ \\
\hline & $(0.0162)$ & $(0.0144)$ & $(0.0116)$ \\
\hline \multirow[t]{2}{*}{ Foreign Entry - Eleven Quarters After } & $-0.0332 * *$ & $-0.0339 * *$ & $-0.0307 * *$ \\
\hline & $(0.0162)$ & $(0.0145)$ & $(0.0124)$ \\
\hline \multirow[t]{2}{*}{ Foreign Entry - Twelve Quarters After } & $-0.0403 * *$ & $-0.0398 * * *$ & $-0.0364 * * *$ \\
\hline & $(0.0165)$ & $(0.0148)$ & $(0.0127)$ \\
\hline \multirow[t]{2}{*}{ Foreign Entry - More Than Twelve Quarters After (Unbalanced) } & $-0.0438 *$ & $-0.0426^{* *}$ & $-0.0388 * *$ \\
\hline & $(0.0223)$ & $(0.0185)$ & $(0.0157)$ \\
\hline P-Value (Point Estimate 12 Quarters After = Point Estimate from Full Sample) & 0.5871 & 0.8537 & 0.6945 \\
\hline Month FX & $\checkmark$ & $\checkmark$ & $\checkmark$ \\
\hline Barcode-By-Store FX & $\checkmark$ & $\checkmark$ & $\checkmark$ \\
\hline Product Group-By-Store Type-By-Month FX & $x$ & $\checkmark$ & $\checkmark$ \\
\hline Region-By-Month FX & $x$ & $\checkmark$ & $\checkmark$ \\
\hline Municipality Size-By-Month FX & $x$ & $\checkmark$ & $\checkmark$ \\
\hline Control for Local Government Expenditure & $x$ & $x$ & $\checkmark$ \\
\hline Observations & $2,933,444$ & $2,601,794$ & $2,317,968$ \\
\hline R-squared & 0.996 & 0.996 & 0.996 \\
\hline Municipality Clusters & 69 & 69 & 58 \\
\hline
\end{tabular}

Notes: The table replicates the first three columns in Table 2 of the paper after excluding municipalities that experienced their first foreign entry over the estimation period and there were more than two foreign stores in the municipality by the end of the estimation period (i.e. we restrict attention to foreign entry events involving only a single store opening). $* 10 \%,{ }^{* *} 5 \%,{ }^{* * *} 1 \%$ significance levels. 
Table A.5: Effect on Municipality Average Incomes and Employment

\begin{tabular}{|c|c|c|c|c|c|c|c|}
\hline & (1) & $(2)$ & (3) & (4) & (5) & (6) & $(7)$ \\
\hline Dependent Variable: & $\begin{array}{l}\text { Log Monthly } \\
\text { Income }\end{array}$ & $\begin{array}{l}\text { Log Monthly } \\
\text { Income }\end{array}$ & $\begin{array}{l}\text { Log Monthly } \\
\text { Income }\end{array}$ & Employed & Employed & Employed & $\begin{array}{l}\text { Log Municipality } \\
\text { Population }\end{array}$ \\
\hline Foreign Entry - More Than Four Quarters Before (Unbalanced) & $\begin{array}{c}-0.0254 * * \\
(0.0126)\end{array}$ & $\begin{array}{l}-0.0136 \\
(0.0123)\end{array}$ & $\begin{array}{l}-0.0173 \\
(0.0161)\end{array}$ & $\begin{array}{l}-0.00170 \\
(0.00255)\end{array}$ & $\begin{array}{l}-0.000770 \\
(0.00282)\end{array}$ & $\begin{array}{l}-0.00154 \\
(0.00376)\end{array}$ & $\begin{array}{l}-0.00257 \\
(0.0359)\end{array}$ \\
\hline Foreign Entry - Four Quarters Before & $\begin{array}{l}-0.0238 \\
(0.0146)\end{array}$ & $\begin{array}{l}-0.0182 \\
(0.0147)\end{array}$ & $\begin{array}{l}-0.0160 \\
(0.0179)\end{array}$ & $\begin{array}{c}-0.00502 * \\
(0.00283)\end{array}$ & $\begin{array}{c}-0.00591 * * \\
(0.00296)\end{array}$ & $\begin{array}{l}-0.00334 \\
(0.00392)\end{array}$ & $\begin{array}{l}-0.00445 \\
(0.0202)\end{array}$ \\
\hline Foreign Entry - Three Quarters Before & $\begin{array}{l}-0.0176 \\
(0.0122)\end{array}$ & $\begin{array}{l}-0.0152 \\
(0.0125)\end{array}$ & $\begin{array}{l}-0.00533 \\
(0.0120)\end{array}$ & $\begin{array}{l}-0.00218 \\
(0.00270)\end{array}$ & $\begin{array}{l}-0.00193 \\
(0.00273)\end{array}$ & $\begin{array}{l}-0.000556 \\
(0.00340)\end{array}$ & $\begin{array}{l}-0.00122 \\
(0.0144)\end{array}$ \\
\hline Foreign Entry - Two Quarters Before (Omitted) & $\begin{array}{c}0 \\
(0)\end{array}$ & $\begin{array}{c}0 \\
(0)\end{array}$ & $\begin{array}{c}0 \\
(0)\end{array}$ & $\begin{array}{c}0 \\
(0)\end{array}$ & $\begin{array}{c}0 \\
(0)\end{array}$ & $\begin{array}{c}0 \\
(0)\end{array}$ & $\begin{array}{c}0 \\
(0)\end{array}$ \\
\hline Foreign Entry - One Quarter Before & $\begin{array}{l}-0.0182 \\
(0.0153)\end{array}$ & $\begin{array}{l}-0.0191 \\
(0.0142)\end{array}$ & $\begin{array}{l}-0.0126 \\
(0.0161)\end{array}$ & $\begin{array}{l}-0.00629^{*} \\
(0.00333)\end{array}$ & $\begin{array}{c}-0.00839 * * * \\
(0.00316)\end{array}$ & $\begin{array}{l}-0.00496 \\
(0.00355)\end{array}$ & $\begin{array}{c}0.0209 \\
(0.0165)\end{array}$ \\
\hline Foreign Entry - One Quarter After & $\begin{array}{l}-0.0150 \\
(0.0130)\end{array}$ & $\begin{array}{l}-0.0170 \\
(0.0126)\end{array}$ & $\begin{array}{l}-0.0144 \\
(0.0154)\end{array}$ & $\begin{array}{l}-0.00305 \\
(0.00275)\end{array}$ & $\begin{array}{l}-0.00485^{*} \\
(0.00283)\end{array}$ & $\begin{array}{l}-0.00283 \\
(0.00388)\end{array}$ & $\begin{array}{c}0.0153 \\
(0.0155)\end{array}$ \\
\hline Foreign Entry - Two Quarters After & $\begin{array}{l}0.00197 \\
(0.0156)\end{array}$ & $\begin{array}{l}-0.00866 \\
(0.0157)\end{array}$ & $\begin{array}{c}0.0102 \\
(0.0176)\end{array}$ & $\begin{array}{l}0.000328 \\
(0.00284)\end{array}$ & $\begin{array}{l}-0.000343 \\
(0.00281)\end{array}$ & $\begin{array}{c}0.00217 \\
(0.00397)\end{array}$ & $\begin{array}{c}0.0234 \\
(0.0178)\end{array}$ \\
\hline Foreign Entry - Three Quarters After & $\begin{array}{l}-0.0243 \\
(0.0154)\end{array}$ & $\begin{array}{c}-0.0344 * * \\
(0.0155)\end{array}$ & $\begin{array}{l}-0.0193 \\
(0.0198)\end{array}$ & $\begin{array}{l}-0.00270 \\
(0.00315)\end{array}$ & $\begin{array}{l}-0.00371 \\
(0.00312)\end{array}$ & $\begin{array}{c}0.00110 \\
(0.00496)\end{array}$ & $\begin{array}{l}0.00675 \\
(0.0188)\end{array}$ \\
\hline Foreign Entry - Four Quarters After & $\begin{array}{l}-0.0217 \\
(0.0166)\end{array}$ & $\begin{array}{l}-0.0309 * \\
(0.0162)\end{array}$ & $\begin{array}{l}-0.0128 \\
(0.0230)\end{array}$ & $\begin{array}{c}3.82 \mathrm{e}-05 \\
(0.00377)\end{array}$ & $\begin{array}{l}-0.00198 \\
(0.00341)\end{array}$ & $\begin{array}{c}5.28 \mathrm{e}-05 \\
(0.00508)\end{array}$ & $\begin{array}{c}0.0346 \\
(0.0233)\end{array}$ \\
\hline Foreign Entry - Five Quarters After & $\begin{array}{l}-0.0111 \\
(0.0156)\end{array}$ & $\begin{array}{l}-0.0243 \\
(0.0165)\end{array}$ & $\begin{array}{l}0.000488 \\
(0.0226)\end{array}$ & $\begin{array}{l}0.000464 \\
(0.00336)\end{array}$ & $\begin{array}{l}-0.000865 \\
(0.00318)\end{array}$ & $\begin{array}{c}0.00429 \\
(0.00572)\end{array}$ & $\begin{array}{c}0.0347 \\
(0.0293)\end{array}$ \\
\hline Foreign Entry - Six Quarters After & $\begin{array}{l}-0.00181 \\
(0.0152)\end{array}$ & $\begin{array}{l}-0.0171 \\
(0.0155)\end{array}$ & $\begin{array}{l}0.00173 \\
(0.0254)\end{array}$ & $\begin{array}{l}-0.00344 \\
(0.00448)\end{array}$ & $\begin{array}{l}-0.00456 \\
(0.00407)\end{array}$ & $\begin{array}{l}0.000742 \\
(0.00671)\end{array}$ & $\begin{array}{c}0.0255 \\
(0.0291)\end{array}$ \\
\hline Foreign Entry - Seven Quarters After & $\begin{array}{c}0.0206 \\
(0.0156)\end{array}$ & $\begin{array}{l}0.00294 \\
(0.0165)\end{array}$ & $\begin{array}{c}0.0151 \\
(0.0243)\end{array}$ & $\begin{array}{c}0.00150 \\
(0.00323)\end{array}$ & $\begin{array}{l}0.000674 \\
(0.00334)\end{array}$ & $\begin{array}{c}0.00450 \\
(0.00799)\end{array}$ & $\begin{array}{c}0.0123 \\
(0.0312)\end{array}$ \\
\hline Foreign Entry - Eight Quarters After & $\begin{array}{c}0.0105 \\
(0.0188)\end{array}$ & $\begin{array}{l}-0.00773 \\
(0.0189)\end{array}$ & $\begin{array}{l}0.00850 \\
(0.0231)\end{array}$ & $\begin{array}{l}-0.00212 \\
(0.00324)\end{array}$ & $\begin{array}{l}-0.00378 \\
(0.00344)\end{array}$ & $\begin{array}{c}0.00143 \\
(0.00696)\end{array}$ & $\begin{array}{c}0.0244 \\
(0.0349)\end{array}$ \\
\hline Foreign Entry - Nine Quarters After & $\begin{array}{l}0.00104 \\
(0.0173)\end{array}$ & $\begin{array}{l}-0.0147 \\
(0.0185)\end{array}$ & $\begin{array}{l}0.00362 \\
(0.0275)\end{array}$ & $\begin{array}{l}-0.00253 \\
(0.00379)\end{array}$ & $\begin{array}{l}-0.00503 \\
(0.00402)\end{array}$ & $\begin{array}{c}0.00264 \\
(0.00893)\end{array}$ & $\begin{array}{c}0.0345 \\
(0.0340)\end{array}$ \\
\hline Foreign Entry - Ten Quarters After & $\begin{array}{c}0.0203 \\
(0.0179)\end{array}$ & $\begin{array}{c}0.000264 \\
(0.0196)\end{array}$ & $\begin{array}{l}0.00489 \\
(0.0248)\end{array}$ & $\begin{array}{c}0.00304 \\
(0.00334)\end{array}$ & $\begin{array}{c}0.00106 \\
(0.00369)\end{array}$ & $\begin{array}{c}0.00867 \\
(0.00889)\end{array}$ & $\begin{array}{c}0.0132 \\
(0.0329)\end{array}$ \\
\hline Foreign Entry - Eleven Quarters After & $\begin{array}{l}-0.00659 \\
(0.0177)\end{array}$ & $\begin{array}{l}-0.0283 \\
(0.0194)\end{array}$ & $\begin{array}{l}-0.00870 \\
(0.0249)\end{array}$ & $\begin{array}{l}0.000817 \\
(0.00379)\end{array}$ & $\begin{array}{c}-0.000496 \\
(0.00390)\end{array}$ & $\begin{array}{c}0.00934 \\
(0.00938)\end{array}$ & $\begin{array}{l}0.00389 \\
(0.0335)\end{array}$ \\
\hline Foreign Entry - Twelve Quarters After & $\begin{array}{c}0.0126 \\
(0.0150)\end{array}$ & $\begin{array}{c}-0.00936 \\
(0.0159)\end{array}$ & $\begin{array}{c}0.0177 \\
(0.0278)\end{array}$ & $\begin{array}{c}0.00395 \\
(0.00348)\end{array}$ & $\begin{array}{c}0.00267 \\
(0.00345)\end{array}$ & $\begin{array}{l}0.00899 \\
(0.0102)\end{array}$ & $\begin{array}{l}-0.00810 \\
(0.0360)\end{array}$ \\
\hline Foreign Entry - More Than Twelve Quarters After (Unbalanced) & $\begin{array}{l}0.0350 * \\
(0.0185)\end{array}$ & $\begin{array}{l}-0.00282 \\
(0.0221)\end{array}$ & $\begin{array}{l}0.00683 \\
(0.0286)\end{array}$ & $\begin{array}{l}0.000515 \\
(0.00313)\end{array}$ & $\begin{array}{l}-0.00160 \\
(0.00338)\end{array}$ & $\begin{array}{l}0.00368 \\
(0.0101)\end{array}$ & $\begin{array}{l}-0.00663 \\
(0.0381)\end{array}$ \\
\hline Quarter FX & $\checkmark$ & $\checkmark$ & $\checkmark$ & $\checkmark$ & $\checkmark$ & $\checkmark$ & $\checkmark$ \\
\hline Municipality FX & $\checkmark$ & $\checkmark$ & $\checkmark$ & $\checkmark$ & $\checkmark$ & $\checkmark$ & $\checkmark$ \\
\hline Person Controls & $\checkmark$ & $\checkmark$ & $\checkmark$ & $\checkmark$ & $\checkmark$ & $\checkmark$ & $x$ \\
\hline Region-By-Quarter FX & $x$ & $\checkmark$ & $x$ & $x$ & $\checkmark$ & $x$ & $\checkmark$ \\
\hline Municipality Size-By-Quarter FX & $x$ & $\checkmark$ & $x$ & $x$ & $\checkmark$ & $x$ & $\checkmark$ \\
\hline Person FX & $x$ & $x$ & $\checkmark$ & $x$ & $x$ & $\checkmark$ & $x$ \\
\hline Observations & $4,307,362$ & $4,307,362$ & $4,307,362$ & $5,610,685$ & $5,610,685$ & $5,610,685$ & 9,702 \\
\hline R-squared & 0.300 & 0.301 & 0.809 & 0.020 & 0.021 & 0.561 & 0.982 \\
\hline Number of Individuals & $1,579,372$ & $1,579,372$ & $1,579,372$ & $1,796,587$ & $1,796,587$ & $1,796,587$ & $1,796,587$ \\
\hline Number of Municipality Clusters & 273 & 273 & 273 & 273 & 273 & 273 & 273 \\
\hline
\end{tabular}

Notes: Table reports regressions of log monthly income or individual employment indicators on 16 quarterly treatment effects and 2 pre and post event study dummies. The data come from the 273 urban municipalities in the quarterly microdata of the Mexican employment and occupation surveys over the period 2002-2012. The reference category are incomes or employment propensities two quarters before foreign entry. The dependent variable in columns 1-3 is individual log monthly income and individual employment dummies in columns 4-6. Column 7 calculates population at the municipality level by summing the survey weights and regresses log municipality population on quarterly treatment effects. To be consistent with previous columns, this regression is weighted by municipality population. The regressions include different combinations of fixed effects and controls as indicated in the table. All regressions are weighted by household survey weights. Standard errors are clustered at the municipality level and reported in parentheses. ${ }^{*} 10 \%, * * 5 \%, * * * 1 \%$ significance levels. 
Table A.6: Household Welfare Effect - Heterogeneity and Alternative Weightings

\begin{tabular}{|c|c|c|c|c|c|c|c|}
\hline \multirow[b]{3}{*}{ Dependent Variable: } & $(1)$ & $(2)$ & (3) & (4) & $(5)$ & (6) & (7) \\
\hline & \multicolumn{7}{|c|}{ Household sample rewighted by population at 2000 Census (Exact Under CES Approach) } \\
\hline & Total Effect & $\begin{array}{l}\text { Direct Price } \\
\text { Index Effect }\end{array}$ & $\begin{array}{c}\text { Pro-Competitive } \\
\text { Price Effect }\end{array}$ & $\begin{array}{c}\text { Pro-Competitive } \\
\text { Exit Effect }\end{array}$ & $\begin{array}{c}\text { Retail Labor } \\
\text { Income Effect }\end{array}$ & $\begin{array}{c}\text { Retail Profit } \\
\text { Effect }\end{array}$ & $\begin{array}{c}\text { Other Income } \\
\text { Effect }\end{array}$ \\
\hline Average Effect & $\begin{array}{l}0.0578 * * * \\
(0.00203)\end{array}$ & $\begin{array}{l}0.0547 * * * \\
(0.000618)\end{array}$ & $\begin{array}{l}0.0156^{* * * *} \\
(0.000307)\end{array}$ & $\begin{array}{c}-0.00695 * * * \\
(0.000121)\end{array}$ & $\begin{array}{c}-0.00438 * * * \\
(0.000697)\end{array}$ & $\begin{array}{c}-0.00333 * * * \\
(0.000910)\end{array}$ & $\begin{array}{c}0.00216^{* * *} \\
(0.000645)\end{array}$ \\
\hline Observations (Households) & 12,293 & 12,293 & 12,293 & 12,293 & 12,293 & 12,293 & 12,293 \\
\hline \multirow[t]{2}{*}{ Number of Municipality Clusters } & 240 & 240 & 240 & 240 & 240 & 240 & 240 \\
\hline & $(8)$ & (9) & $(10)$ & $(11)$ & $(12)$ & $(13)$ & (14) \\
\hline Dependent Variable: & Total Effect & $\begin{array}{c}\text { Household samp } \\
\text { Direct Price } \\
\text { Index Effect } \\
\end{array}$ & $\begin{array}{l}\text { rewighted by supe } \\
\text { Pro-Competitive } \\
\text { Price Effect }\end{array}$ & $\begin{array}{l}\text { ermarkets/capita in } \\
\text { Pro-Competitive } \\
\text { Exit Effect }\end{array}$ & $\begin{array}{l}2002 \text { (Exact Un } \\
\text { Retail Labor } \\
\text { Income Effect }\end{array}$ & $\begin{array}{c}\text { CES Approac } \\
\text { Retail Profit } \\
\text { Effect }\end{array}$ & $\begin{array}{c}\text { Other Income } \\
\text { Effect }\end{array}$ \\
\hline Average Effect & $\begin{array}{l}0.0600 * * * \\
(0.00181)\end{array}$ & $\begin{array}{l}0.0542 * * * \\
(0.000675)\end{array}$ & $\begin{array}{l}0.0165^{* * * *} \\
(0.000494)\end{array}$ & $\begin{array}{c}-0.00681 * * * \\
(0.000115)\end{array}$ & $\begin{array}{c}-0.00441 * * * \\
(0.00121)\end{array}$ & $\begin{array}{c}-0.00221 * * * \\
(0.000474)\end{array}$ & $\begin{array}{c}0.00270 * * * \\
(0.000779)\end{array}$ \\
\hline Observations (Households) & 12,293 & 12,293 & 12,293 & 12,293 & 12,293 & 12,293 & 12,293 \\
\hline Number of Municipality Clusters & 240 & 240 & 240 & 240 & 240 & 240 & 240 \\
\hline
\end{tabular}

Notes: Table reports the welfare effects of foreign retail entry from the quantification exercise described in Section 6 . The average effect is the weighted mean across all 12,293 households in the income and expenditure surveys that reside in the 240 urban municipalities that had not yet experienced foreign retail entry at the time of the survey. All panels use the exact and complete CES approach. The top panel weights the household sample so that the distribution of municipality populations at the time of the 2000 census matches the 2000 population distributions in the municipality sample used to calculate the pro-competitive price effects. This is achieved by placing municipalities in the household survey into five bins based on quantiles of the distribution of municipality size in the full municipality sample, and then rescaling the household survey weights to ensure that each bin contains 20 percent of the sample households. The bottom panel weights the household sample in a similar manner so that the distribution of initial competitiveness (supermarkets per capita in 2002) matches the distribution of initial competitiveness in the municipality sample used to calculate the pro-competitive price effects. Standard errors are clustered at the municipality level (but do not use the bootstrap procedure described in Section 6). ${ }^{*} 10 \%,{ }^{* *} 5 \%, * * * 1 \%$ significance levels. 
Table A.7: Household Welfare Effect - Traditional Stores in Separate Nests

\begin{tabular}{|c|c|c|c|c|c|c|c|}
\hline \multirow[b]{3}{*}{ Dependent Variable: } & (1) & $(2)$ & (3) & (4) & (5) & (6) & (7) \\
\hline & \multicolumn{7}{|c|}{ Traditional Stores in Different Nest with Same Elasticity $\eta$ (Exact Under CES Approach) } \\
\hline & Total Effect & $\begin{array}{l}\text { Direct Price } \\
\text { Index Effect }\end{array}$ & $\begin{array}{c}\text { Pro-Competitive } \\
\text { Price Effect }\end{array}$ & $\begin{array}{l}\text { Pro-Competitive } \\
\text { Exit Effect }\end{array}$ & $\begin{array}{l}\text { Retail Labor } \\
\text { Income Effect }\end{array}$ & $\begin{array}{c}\text { Retail Profit } \\
\text { Effect }\end{array}$ & $\begin{array}{c}\text { Other Income } \\
\text { Effect }\end{array}$ \\
\hline Average Effect & $\begin{array}{l}0.0524 * * * \\
(0.00216)\end{array}$ & $\begin{array}{r}0.0474 * * * \\
(0.00191)\end{array}$ & $\begin{array}{l}0.0158 * * * \\
(0.000247)\end{array}$ & $\begin{array}{c}-0.00705^{* * * *} \\
(0.000156)\end{array}$ & $\begin{array}{c}-0.00397 * * * \\
(0.000473)\end{array}$ & $\begin{array}{c}-0.00269 * * * \\
(0.000397)\end{array}$ & $\begin{array}{c}0.00289 * * * \\
(0.000536)\end{array}$ \\
\hline Observations (Households) & 12,293 & 12,293 & 12,293 & 12,293 & 12,293 & 12,293 & 12,293 \\
\hline \multirow[t]{2}{*}{ Number of Municipality Clusters } & 240 & 240 & 240 & 240 & 240 & 240 & 240 \\
\hline & $(8)$ & (9) & $(10)$ & (11) & (12) & (13) & (14) \\
\hline Dependent Variable: & Total Effect & $\begin{array}{l}\text { Traditiona } \\
\text { Direct Price } \\
\text { Index Effect }\end{array}$ & $\begin{array}{c}\text { Stores in Differe } \\
\text { Pro-Competitive } \\
\text { Price Effect }\end{array}$ & $\begin{array}{l}\text { nt Nest with } \eta=2 \text { ( } \\
\text { Pro-Competitive } \\
\text { Exit Effect }\end{array}$ & $\begin{array}{l}\text { Exact Under CE } \\
\text { Retail Labor } \\
\text { Income Effect }\end{array}$ & $\begin{array}{l}\text { Approach) } \\
\text { Retail Profit } \\
\text { Effect }\end{array}$ & $\begin{array}{c}\text { Other Income } \\
\text { Effect }\end{array}$ \\
\hline Average Effect & $\begin{array}{l}0.0442 * * * \\
(0.00246)\end{array}$ & $\begin{array}{r}0.0477 * * * \\
(0.00191)\end{array}$ & $\begin{array}{l}0.0158 * * * \\
(0.000247)\end{array}$ & $\begin{array}{c}-0.0155^{* * *} \\
(0.000551)\end{array}$ & $\begin{array}{c}-0.00397 * * * \\
(0.000473)\end{array}$ & $\begin{array}{c}-0.00269 * * * \\
(0.000397)\end{array}$ & $\begin{array}{c}0.00289 * * * \\
(0.000536)\end{array}$ \\
\hline Observations (Households) & 12,293 & 12,293 & 12,293 & 12,293 & 12,293 & 12,293 & 12,293 \\
\hline \multirow[t]{2}{*}{ Number of Municipality Clusters } & 240 & 240 & 240 & 240 & 240 & 240 & 240 \\
\hline & (15) & $(16)$ & $(17)$ & $(18)$ & (19) & $(20)$ & $(21)$ \\
\hline Dependent Variable: & Total Effect & $\begin{array}{l}\text { Traditiona } \\
\text { Direct Price } \\
\text { Index Effect }\end{array}$ & $\begin{array}{c}\text { Stores in Differe } \\
\text { Pro-Competitive } \\
\text { Price Effect }\end{array}$ & $\begin{array}{l}\text { nt Nest with } \eta=6 \text { ( } \\
\text { Pro-Competitive } \\
\text { Exit Effect }\end{array}$ & $\begin{array}{l}\text { Exact Under CES } \\
\text { Retail Labor } \\
\text { Income Effect }\end{array}$ & $\begin{array}{l}\text { Approach) } \\
\text { Retail Profit } \\
\text { Effect }\end{array}$ & $\begin{array}{c}\text { Other Income } \\
\text { Effect }\end{array}$ \\
\hline Average Effect & $\begin{array}{l}0.0540 * * * \\
(0.00209)\end{array}$ & $\begin{array}{r}0.0473 * * * \\
(0.00191)\end{array}$ & $\begin{array}{l}0.0158 * * * \\
(0.000247)\end{array}$ & $\begin{array}{c}-0.00538 * * * \\
(7.64 \mathrm{e}-05)\end{array}$ & $\begin{array}{c}-0.00397 * * * \\
(0.000473)\end{array}$ & $\begin{array}{c}-0.00269 * * * \\
(0.000397)\end{array}$ & $\begin{array}{c}0.00289 * * * \\
(0.000536)\end{array}$ \\
\hline Observations (Households) & 12,293 & 12,293 & 12,293 & 12,293 & 12,293 & 12,293 & 12,293 \\
\hline Number of Municipality Clusters & 240 & 240 & 240 & 240 & 240 & 240 & 240 \\
\hline
\end{tabular}

Notes: The table reports the welfare effects of foreign retail entry from the quantification exercise described in Section 6 . The average effect is the survey-weighted mean across all 12,293 households in the income and expenditure surveys that reside in the 240 urban municipalities that had not yet experienced foreign retail entry at the time of the survey. The top panel uses the exact and complete CES approach but places all modern stores in a separate upper-tier (Cobb-Douglas) nest next to traditional stores (using the elasticities $\eta_{g h}$ estimated in Section 6.1 for substitution within both traditional and modern nests). The second and third panel carry out the same exercise, but set the elasticity of substitution within the traditional nest equal to 2 and 6 respectively. Standard errors are clustered at the municipality level (but do not use the bootstrap procedure described in Section 6 ). ${ }^{*} 10 \%, * * 5 \%$, $* * 1 \%$ significance levels. 
Table A.8: Heterogeneity of Pro-Competitive Price Effect across Pre-Existing Retail Competition

\begin{tabular}{|c|c|c|c|c|}
\hline Dependent Variable: & $\begin{array}{c}(1) \\
\text { Log Price } \\
\end{array}$ & $\begin{array}{c}(2) \\
\text { Log Price }\end{array}$ & $\begin{array}{c}(3) \\
\text { Log Price }\end{array}$ & $\begin{array}{c}(4) \\
\text { Log Price }\end{array}$ \\
\hline Foreign Entry & $\begin{array}{c}-0.0373 * * * \\
(0.0119)\end{array}$ & $\begin{array}{c}-0.0358 * * \\
(0.0152)\end{array}$ & $\begin{array}{c}-0.0356 * * \\
(0.0170)\end{array}$ & \\
\hline Foreign Entry X Number of Modern Domestic Stores in 2002 & & $\begin{array}{l}-0.000865 \\
(0.00382)\end{array}$ & & \\
\hline $\begin{array}{l}\text { Foreign Entry X Number of Modern Domestic Stores Per } 1000 \\
\text { Inhabitants in } 2002\end{array}$ & & & $\begin{array}{l}-0.215 \\
(1.022)\end{array}$ & \\
\hline Foreign Entry X Below Mean Competition in 2002 & & & & $\begin{array}{l}-0.0364^{*} \\
(0.0206)\end{array}$ \\
\hline Foreign Entry X Above Mean Competition in 2002 & & & & $\begin{array}{c}-0.0378 * * * \\
(0.0111)\end{array}$ \\
\hline Barcode-By-Store FX & $\checkmark$ & $\checkmark$ & $\checkmark$ & $\checkmark$ \\
\hline Product-By-Store Type-By-Month FX & $\checkmark$ & $\checkmark$ & $\checkmark$ & $\checkmark$ \\
\hline Region-By-Month FX & $\checkmark$ & $\checkmark$ & $\checkmark$ & $\checkmark$ \\
\hline Municipality Size-By-Month FX & $\checkmark$ & $\checkmark$ & $\checkmark$ & $\checkmark$ \\
\hline Observations & $2,790,780$ & $2,790,780$ & $2,790,780$ & $2,790,780$ \\
\hline R-squared & 0.996 & 0.996 & 0.996 & 0.996 \\
\hline Number of Municipalities & 76 & 76 & 76 & 76 \\
\hline
\end{tabular}

Notes: Table reports regressions of $\log$ prices at domestic stores on an indicator for foreign entry interacted with measures of the pre-existing level of competition from domestic big box stores. The data come from the Mexican CPI price microdata over the period 2002-2014 covering 120 retail product groups and 76 urban municipalities, with a sampling probability designed to reflect nationally representative urban consumption weights. The basic specification is the same as that reported in column 2 of Table 2 except that the foreign entry effect is averaged across quarters and the estimation sample excludes an adjustment period of 24 months after entry. The first measure of retail competition is the number of domestic big box stores (stores from Chedauri, Soriana, Comercial Mexicana or Gigante) existing at the beginning of the sample in 2002. The second measure is this number per 1000 inhabitants in the municipality. The third measure is an indicator which takes the value of 1 if a municipality is above the mean level of domestic big box stores per capita in 2002. Standard errors are clustered at the municipality level and reported in parentheses. ${ }^{*} 10 \%,{ }^{* *} 5 \%,{ }^{* * *}$ $1 \%$ significance levels. 
Table A.9: Heterogeneity of Post-Entry Foreign Retail Shares across Pre-Existing Retail Competition

\begin{tabular}{|c|c|c|c|}
\hline Dependent Variable: & $\begin{array}{c}(1) \\
\text { Post-Entry Retail } \\
\text { Consumption Share } \\
\text { on Foreign Store } \\
\end{array}$ & $\begin{array}{c}(2) \\
\text { Post-Entry Retail } \\
\text { Consumption Share } \\
\text { on Foreign Store } \\
\end{array}$ & $\begin{array}{c}(3) \\
\text { Post-Entry Retail } \\
\text { Consumption Share } \\
\text { on Foreign Store } \\
\end{array}$ \\
\hline Number of Modern Domestic Stores in 2006 & $\begin{array}{l}-0.00483 * * * \\
(0.00183)\end{array}$ & & \\
\hline $\begin{array}{l}\text { Number of Modern Domestic Stores Per } 1000 \\
\text { Inhabitants in } 2006\end{array}$ & & $\begin{array}{c}-6.958 * * * \\
(1.528)\end{array}$ & \\
\hline Dummy for Below Mean Competition in 2006 & & & $\begin{array}{c}0.0876^{* * *} \\
(0.0227)\end{array}$ \\
\hline Income Controls & $\checkmark$ & $\checkmark$ & $\checkmark$ \\
\hline Observations (Number of Households) & 6,475 & 6,475 & 6,475 \\
\hline R-squared & 0.168 & 0.188 & 0.180 \\
\hline Number of Municipalities & 105 & 105 & 105 \\
\hline
\end{tabular}

Notes: Table reports regressions of household-level retail expenditure shares (from the consumer panel data) of foreign retailers 24 or more months post entry on measures of the pre-existing level of competition from domestic big box stores, and controls for household income bins. The first measure of retail competition is the number of domestic big box stores (stores from Chedauri, Soriana, Comercial Mexicana or Gigante) existing at the beginning of the sample in 2002. The second measure is this number per 1000 inhabitants in the municipality. The third measure is an indicator which takes the value of 1 if a municipality is above the mean level of domestic big box stores per capita in $2002 .{ }^{*} 10 \%$, $* * 5 \%,{ }^{* * *} 1 \%$ significance levels.

\section{B Supplementary Details on the Collection of the Mexican CPI Micro- data and Retail Census Microdata}

\section{B.1 CPI Microdata}

The sampling framework of the Mexican CPI microdata is described in detail in Banco de México (2002), INEGI (2010) and Salas (2006), and follows the guidelines used by the United States that follow the IMF/ILO data collection standards for consumer price inflation measurement and reporting. The Mexican CPI is representative of cities in Mexico with over 20,000 inhabitants in the year 2000.

The price data we use in our estimation comprise two CPI basket definition cycles. From the second half of June 2002 until the second half of December 2010, sampling was based on consumption patterns from the 2000 ENIGH. From the second half of December 2010 to the end of the sample, sampling was based on consumption patterns from the 2008 ENIGH.

The CPI microdata are based on the monthly prices published in the official gazette, Diario Oficial de la Federación, for approximately 83,500 specific goods obtained at approximately 21,000 establishments. To generate these monthly price series, enumerators procure over 235,000 price quotes per month (food items are quoted weekly and non-food items are quoted twice a month). A subset of these price series are for goods that can be considered barcode equivalent based on the specific good description. An example of what we call barcode equivalent is "Cereal box of Kellogg's Zucaritas 400 grams". An example of a non-barcode equivalent good is a roma tomato, in which aspects such as freshness or size can generate unobserved quality variation that can be reflected in prices. Of course, it is not possible to condition on the level of detail we call "barcode- 
equivelent" for non-retail products such as doctor visits, education, hair cuts or housing we use in the estimation of column 5 of Table 2 in the main text since these items typically do not have brands or pack sizes. That said, the CPI microdata quotes are designed to be comparable over time, and so they collect prices of identical services (e.g. the rent for the same flat or the price for a taxi ride along the same route from the same taxi company) over time.

ENIGH provides shares of consumption for every retail product category by outlet type (supermarket, convenience store, department store, price club, specialized store, traditional market, street stall, and informal store). These shares are used to design of enumerator workloads, with enumerators told to obtain prices at regular intervals (every two weeks or every week on the same day) and told which specific goods to obtain quotes from at each outlet. In particular, within each CPI product category, the sample of price quotes is collected from multiple local establishment types so that the resulting sample of price quotes is representative of the outlet type consumption patterns in the ENIGH.

Price quotes include VAT if applicable (food and medicines are exempt from this tax) and are inclusive of any sales or promotions as long as they do not require the use of a coupon the client obtains elsewhere (i.e. in a newspaper cutout), a minimum purchase amount (i.e. buy three get one free promotions), or a specific type of payment (i.e. 10 percent off if the payment is with a Banamex credit card). Enumerators are trained not to simply transcribe posted prices. They instead inquire about prices being actually charged, which is especially relevant in contexts where negotiation is expected such as at street stalls.

The CPI Catalogue of Generic Items gives every enumerator a complete description of the specific goods, points of purchase and number of quotes for specific goods that are to be obtained. For example in the CPI Catalogue for 2005, Tomato (a CPI product category) consists of Roma Tomato and Round Tomato varieties (specific goods). The enumerator obtains four quotes of the first and one of the latter. This is done so that the number of quotes reflects the relative importance of each specific good in the product category. Continuing with the example, in the city of Iguala, Tomato quotes are to be obtained as follows: one quote at a traditional market, one at a fruit and vegetable traditional retailer, two at Walmart, one at a Tianguis (street market) (Salas, 2006). This is done so that price quotes reflect ENIGH consumption patterns by outlet type.

Note that the prices from members-only stores are not inclusive of membership fees. However, such stores account for only 0.8 percent of quotes (Salas, 2006) so we do not explicitly take this feature into account in our estimation in Table 2 of the main text.

To maintain representativeness of household consumption over time, new specific goods are continuously introduced. This occurs whenever a new brand becomes relevant in which case local or national guidelines are updated detailing that the new specific is to be quoted henceforth. The procedure for missing quotes is that whenever this occurs for idiosyncratic reasons (such as the store being closed for the day) the price is imputed so that the percent change in the price is equal to that of other specific goods in the product group in that month and city-which follows ILO (2006) guidelines. For goods that are known to be seasonal, such as winter coats, the specific good to be quoted changes with the season. This is an important reason why we estimate the pro-competitive effects in Table 2 using only the subsample of barcode equivalent goods.

If the item is not simply missing on a single occasion but in fact no longer being sold, a replacement procedure is initiated. This procedure consists of starting a new specific good time series using central office guidelines and parameters from the Catalogue with authorization from the central office. In cases in which the store shuts down a replacement of the same retailer type is proposed. Again, this is done jointly with central office supervisors so that practices are homogenous across cities. For both item or store replacement, the published price quotes indicate that there was a specific good or store replacement. We use this information to create a new barcode-by-store time 
series whenever this occurs. Note that because emphasis is given to comparability of price quotes over time, whenever a municipality experiences foreign supermarket entry this is not immediately reflected in the CPI price collection data. This feature is not problematic in our approach, since the CPI microdata is only required to estimate the pro-competitive effects among pre-existing retailers.

\section{B.2 Retail Census Microdata}

We obtain profits for traditional retailers from the Retail Census (part of the Economic Census) which is fielded every five years and has the advantage that it provides a census of all fixedlocation establishments in every municipality. The only establishments not in the Economic Census are mobile street vendors. The Economic Census does not contain establishment identifiers, preventing a firm-level link across census years.

The survey is administered by INEGI using an establishment-level questionnaire collected by trained enumerators. The results are not cross-checked against corporate tax returns, nor used for tax assessment purposes. In Mexico the majority of establishments, and especially traditional retailers, are informal and do not file tax returns (Busso, Fazia, and Levy 2012).

The measure of profits we use is defined as Total revenue from sale of goods and services minus Sum of expenditures on goods and services minus Labor expenditures. In turn, each of these is obtained by adding revenue and expenditures from a set of related questions. For example, Total revenue from sale of goods and services is the sum of Revenue from sales of goods purchased for resale, Revenue from rendered services, Revenue from sale of goods produced by the firm, Revenue from leasing properties, Revenue from royalties, and Other income from provision of goods and services. This measure excludes taxes, financial income, subsidies, income not derived from the main activity of the firm, and inventories. For small traditional retailers these variables are zero for the overwhelming majority of establishments.

Establishment-level outcomes are winsorized at the 1 percent level and then aggregated to municipality-level sums and means before taking logs. At the municipality level there are very few instances of negative total or average profits and we take a log transformation on either side of 0 (a log modulus transformation defined as $\operatorname{sgn}(x) \cdot \log (|x|+1)$ and described in John and Draper, 1980).

\section{Alternative Estimates of the CES Elasticity Parameter}

Section 6.1 presents our procedure for estimating the elasticity of substitution across retail stores and explores the sensitivity of the estimates to two different IV strategies and the addition of multiple sets of fixed effects. In this section of the online appendix, we explore the sensitivity of our elasticity estimates to several additional alternative specifications.

Column 1 of Table C. 1 repeats the specification we use to carry out our quantification (columns 7 and 23 of Table 8). Since the Stone price indices we use for the store-product group price index $\ln r_{g s h m t}$ in equation 21 do not account for variety differences across outlets within the same chain, if variety and price were strongly correlated, our elasticity estimates using only price variation to calculate price indices may be biased. To address this concern, in column 2 we include explicit controls for the logged number of varieties observed in each store-by-product-group-bymunicipality-by-time-period. While reassuringly the log number of varieties enter positively and highly significantly as expected, the estimated elasticities rise only very slightly once variety is controlled for, suggesting any correlation is limited.

A second worry is that we recover the store-by-product group price index $\ln r_{g s h m t}$ from the store fixed effects in a regression of budget-share-weighted log prices at the barcode-level on both store and barcode fixed effects, where this regression is run separately for every product-group-byincome-group-by-municipality-by-period cell. Within a particular store and month, the barcodes 
with lower relative prices are more likely to be purchased and enter the sample. Hence, the average price gaps, once we aggregate up to the product-level, may not be representative of actual price gaps between stores and over time. Additionally, smaller stores with fewer customers will have noisier price quotes. While these biases are hard to correct for, or even sign, we report three robustness checks that reassure us that any biases are not too substantial. Column 3 reproduces our baseline specification, but using unweighted log prices (rather than budget-share weighted $\log$ prices) in estimating the Stone price indexes. Column 4 reports an estimate akin to the between estimator that exploits only the cross-sectional variation. In particular, we run the baseline specification separately for all 14 quarterly time periods and report the average and standard deviation of the resulting 14 coefficients (weighting the averages by the inverse of the variance of the estimate). ${ }^{46}$ Column 5 restricts attention to more commonly observed products, those which we observe in at least one quarter of all the store-brands that operate in that product group. ${ }^{47} \mathrm{Al}-$ though the elasticity estimates change, particularly in the latter case, they are all within the range of elasticities reported in Table 10.

Finally, we address concerns with the IV strategy. For our IV strategy to work, we require that the stores in our estimation sample have some component of their local price that is set regionally or nationally rather than locally. Columns 6 and 7 repeat our baseline specification but removing stores where this assumption is less tenable (where either the correlation between barcode-level prices in one municipality with the same barcode in the same store in other states in the same region is negative (column 6), or below the mean correlation (column 7)). As above, although the elasticity estimates change, they remain within the range of elasticities reported in Table 10.

\footnotetext{
${ }^{46}$ As the first stages of the IV are weak when run quarter by quarter, we conduct the first stage using the full dataset and run only the second stage quarter by quarter.

${ }^{47}$ No products are recorded as available in all retailers. The most common product is available in 85 percent of stores, while the median product observation is available in 44 percent of stores.
} 


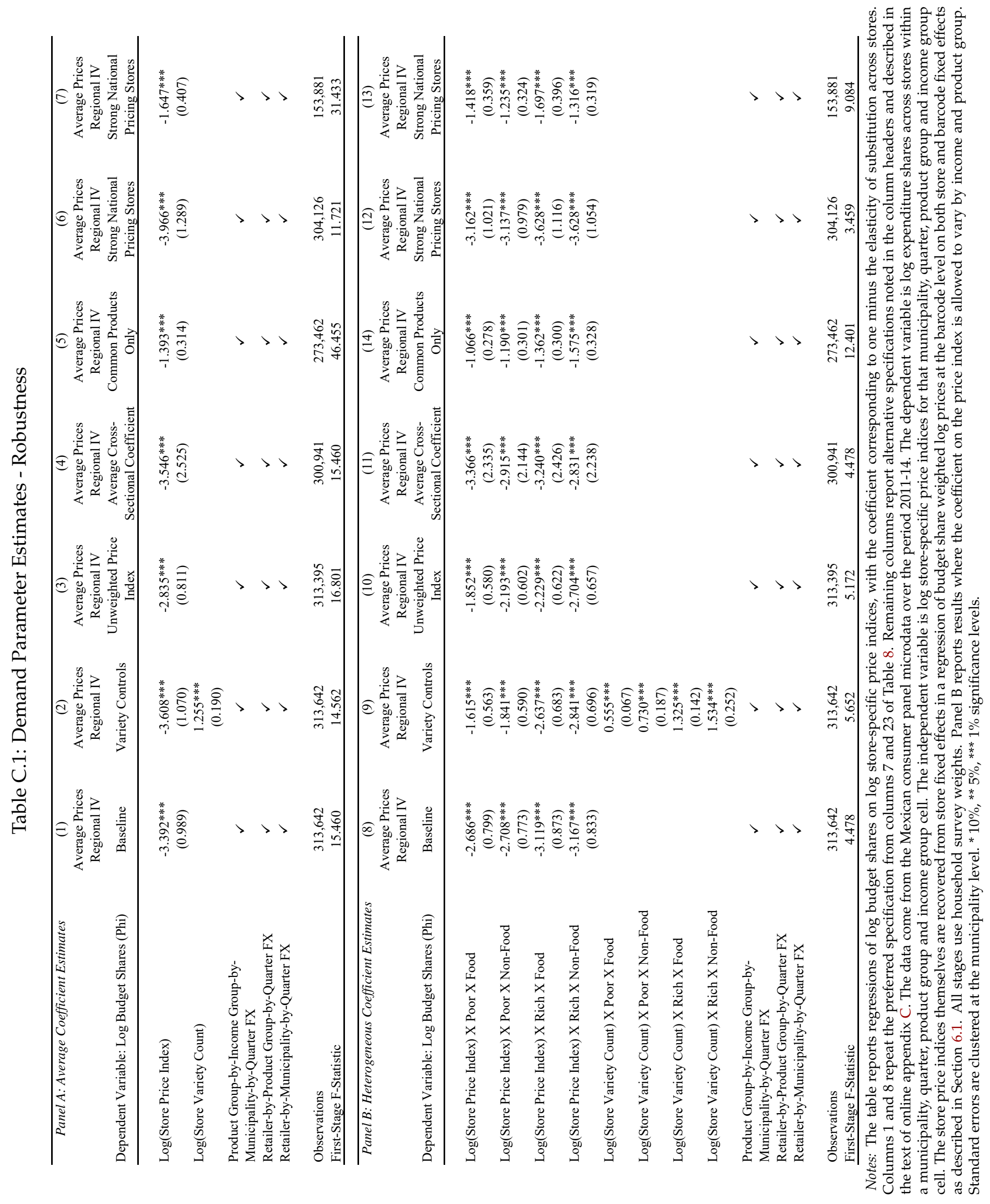

